UNIVERSIDADE DE SÃO PAULO

ESCOLA DE ENFERMAGEM

ESCOLA DE ENFERMAGEM DE RIBEIRÃO PRETO

PROGRAMA INTERUNIDADES DE DOUTORAMENTO EM ENFERMAGEM

RUTH FRANÇA CIZINO DA TRINDADE

\title{
Entre o sonho e a realidade: a maternidade na adolescência sob a ótica de um grupo de mulheres da periferia da cidade de Maceió - Alagoas
}




\section{Entre o sonho e a realidade: a maternidade na adolescência sob a ótica de um grupo de mulheres da periferia da cidade de Maceió - Alagoas}

Tese apresentada à Escola de Enfermagem de Ribeirão Preto da Universidade de São Paulo para obtenção do título de Doutora em Enfermagem no Programa Interunidades de Doutoramento em Enfermagem.

Área de Concentração - Sociedade, Saúde e Enfermagem.

Orientadora: Profa. Dra. Ana Maria de Almeida

RIBEIRÃO PRETO 
AUTORIZO A REPRODUÇÃO E DIVULGAÇÃO TOTAL OU PARCIAL DESTE TRABALHO, POR QUALQUER MEIO CONVENCIONAL OU ELETRÔNICO, PARA FINS DE ESTUDO E PESQUISA, DESDE QUE CITADA A FONTE.

FICHA CATALOGRÁFICA

Trindade, Ruth França Cizino da

Entre o sonho e a realidade: a maternidade na adolescência sob a ótica de um grupo de mulheres da periferia da cidade de Maceió Alagoas_Ruth França Cizino da Trindade; orientadora Ana Maria de Almeida.

- Ribeirão Preto, 2005.

$212 \mathrm{f}$.

Tese (Doutorado - Programa Interunidades de Doutoramento em Enfermagem. Área de Concentração - Sociedade, Saúde e Enfermagem) Escola de Enfermagem e Escola de Enfermagem de Ribeirão Preto da Universidade de São Paulo.

1. Gravidez na adolescência 2. Saúde reprodutiva 3. Saúde da mulher

4. Comportamento reprodutivo 5. Identidade de gênero 6. Feminismo. 


\section{FOLHA DE APROVAÇ̃̃̃}

Ruth França Cizino da Trindade

Entre o sonho e a realidade: a maternidade na adolescência sob a ótica de um grupo de mulheres da periferia da cidade de Maceió - Alagoas

Tese apresentada à Escola de Enfermagem e Escola de Enfermagem de Ribeirão Preto da Universidade de São Paulo para obtenção do título de Doutora.

Área de Concentração: Sociedade, Saúde e Enfermagem

Aprovado em:

\section{Banca Examinadora}

Profa. Dra. Ana Maria de Almeida

Instituição: EERP-USP

Assinatura:

Profa. Dra. Maria das Graças Bonfim de Carvalho

Instituição: EERP-USP

Assinatura:

Profa. Dra. Maria José Clapis

Instituição: EERP-USP

Assinatura:

Profa. Dra. Maria Cristina Figueiredo Trezza

Instituição: UFAL

Assinatura:

Prof. Dr. Manuel Antonio dos Santos

Instituição: FMRP-USP

Assinatura: 
Dedico este trabalho à Maria Anunciada, minha mãe, por estar sempre presente em minha caminhada, por ter superado algumas adversidades e por ser, para mim, um exemplo de mulher inteligente, firme e independente. Ao meu pai, José Cizino, que apesar de não estar mais fisicamente entre nós, me deu o privilégio de ser sua filha e deixou como exemplo um homem companheiro, amoroso, forte, inteligente e culto.

Aos meus irmãos José Ricardo, Elizabeth e Sileida, aos meus sobrinhos Rodrigo, Rafael, Ana Carolina, Ariane e Ananda, meus cunhados Ájax e Suely, pelo amor e carinho para comigo e por serem presenças constantes em minha vida, mesmo quando estamos distantes. 
À Orquídea, Evelin, Maria, Uliane, Taís, Tieta, Leônia, Vitória, Aparecida, Vera, Esmeralda, Mariana, Caroline e Isadora que, apesar das dificuldades de suas vidas foram capazes de compartilhar comigo suas histórias de vida, o que possibilitou a realização deste estudo, como também o meu enriquecimento profissional e pessoal. $A$ todas elas, o meu, muito obrigada. 


\section{Agradecimentos}

Às energias superiores por terem me dado a oportunidade de realizar este trabalho.

À Escola de Enfermagem de Ribeirão Preto-USP e ao Programa Interunidades de Doutoramento de Enfermagem, pela oportunidade de conseguir esta qualificação profissional.

À Prof ${ }^{a} D r^{a}$ Ana Maria Almeida por ter participado desta trajetória, apoiando-me e orientando-me com clareza, enriquecendo o conteúdo deste trabalho, dando-me a oportunidade de desenvolver como pesquisadora.

À colaboração dos agentes comunitários de saúde da Unidade Docente Assistencial de Saúde da Família: Gizélia, Marieta, Josefa, Maria de Fátima, Antônio, Verônica, Alberto e Marta.

Aos meus colegas de disciplina do Departamento de Enfermagem da Universidade Federal de Alagoas, pelo apoio a minha liberação para fazer o Doutorado.

Ao Departamento de Enfermagem e ao Hospital Universitário da Universidade Federal de Alagoas, nas pessoas da Prof ${ }^{a}$ Célia Rosendo Alves e Prof ${ }^{a}$ Marcina Maria Barros e Enfas. Lindinalva Freitas e Dilma, Teixeira de O. Canuto pela minha liberação das atividades profissionais o que possibilitou dedicar-me integralmente ao doutorado e à realização deste estudo.

À Secretária de Saúde do Município de Maceió por permitir a realização desta pesquisa com as mulheres atendidas pela Unidade de Saúde da Família do Frei Damião.

À vida por ter colocado em meu caminho professores e colegas com quem me relacionei durante o curso de doutorado e que direta ou indiretamente me 
auxiliaram na construção deste estudo, os quais foram muitos, por isso não citarei nomes com risco de esquecer de alguém.

À Profa. Verena Stolcke por ter aceitado me orientar no estágio de doutorado no exterior, que realizei em 2003, na Universidad Autónoma de Barcelona (UAB) Espanha, pelo discussão do meu projeto de estudo incentivo $e$ orientação o que me auxiliou a crescer como pesquisadora.

Ao Prof. José Luis Molina, coordenador do Programa de pós-graduação do departamento de Antropologia da UAB, pelas gestões durante o processo de negociação do estágio nesta universidade e apoio durante a realização do mesmo.

À CAPES que forneceu durante o período de agosto de 2001 a dezembro de 2003 a bolsa PICDT e a bolsa de estudo para estágio no exterior no período de janeiro a julho de 2004.

Ao CNPq por uma bolsa de apoio ao doutorado, concedida no período de fevereiro de 2005 ao termino do curso. 
Seus corações sabem em silêncio os segredos dos dias e das noites.

Mas seus ouvidos anseiam pelo som do conhecimento de seu coração.

Pois querem saber em palavras aquilo que sempre souberam em pensamento.

Querem tocar com os dedos o corpo nu de seus sonhos.

Kahil Gibran, 2002 


\section{RESUMO}

TRINDADE, R.F.C. Entre o sonho e a realidade: a maternidade na adolescência sob a ótica de um grupo de mulheres da periferia da cidade de Maceió - Alagoas. 2005. 112 f. Tese (Doutorado) - Escola de Enfermagem de Ribeirão Preto. Universidade de São Paulo. Ribeirão Preto, 2005.

Este foi um estudo de natureza qualitativa, que teve como objetivo compreender, a partir da experiência de mulheres que se tornaram mães na adolescência, o significado da maternidade no contexto de vida destas mães. Participaram 14 mulheres na faixa etária de 20 a 24 anos, residentes na periferia de Maceió, capital do estado de Alagoas. A coleta de informação foi realizada por meio de entrevistas, utilizando a história oral temática como procedimento metodológico. Foram construídas narrativas, a partir das histórias de vida das mulheres, posteriormente, analisadas à luz do referencial de gênero. Observamos que as entrevistadas tiveram sua iniciação sexual durante o período de namoro quando não haviam recebido orientações prévias sobre sexualidade ou saúde reprodutiva. Algumas mulheres conviviam com seus parceiros quando aconteceu a gravidez, porém, mesmo assim, consideraram esse fato inesperado. Houve aceitação da gravidez pela maioria delas, e também ocorreu a união, ainda que não de maneira legalizada, de muitos casais que não viviam juntos. Tentativas de abortamento, quando da não-aceitação imediata do parceiro, foram relatadas. As questões de gênero mostram-se presentes nas relações conjugais, com os parceiros figurando como provedores da família e as mulheres mantidas sob sua dependência, centradas no ambiente doméstico, assumindo responsabilidade pelo cuidado da casa, dos filhos e do companheiro. Os homens agiam mais livremente, mantendo relações extraconjugais e chegavam a agredir suas mulheres, em casa. Apesar de ressentidas com essa atitude dos companheiros, elas mantinham o relacionamento com eles. As entrevistadas deixaram explícito que lamentavam a perda da liberdade, do lazer, da oportunidade de trabalho e de estudo ao assumirem a maternidade. Por outro lado, enfatizaram seu não-arrependimento por terem levado a gravidez até o fim. Assim o cotidiano dessas mulheres parece centralizado no cuidar dos filhos, conscientes de que são elas as principais responsáveis por eles, voltando todos os seus projetos de vida para este cuidado. A vida dessas mães é marcada pelas condições de desigualdade em que vivem, social-econômica-cultural e de gênero. Dessa forma, apesar de seus desejos manifestos elas encontram poucas oportunidades objetivas de romperem com o contexto de vida em que estão inseridas.

Palavras-Chave: Gravidez na adolescência. Saúde reprodutiva. Saúde da mulher. Comportamento reprodutivo. Identidade de gênero. Feminismo. 


\begin{abstract}
TRINDADE, R.F.C. Between dream and reality: maternity in adolescence under the vision of a group of women from Maceio city suburbs - Alagoas, Brazil 2005. $212 \mathrm{f}$. Thesis (Doctorate) - Nursing School at Ribeirão Preto. University of São Paulo. Ribeirão Preto, 2005.

A qualitative study, which aimed at comprehending, by the experiences of women who became mother in adolescence, the meaning of maternity in their context of life. Fourteen women from 20 to 24 years old, who lived in Maceio suburbs, capital of Alagoas State, took part in the study. The information collection was carried out through interviews, using thematic oral history as methodological procedure. We built narratives from these women's life history and, later, we analyzed these narratives based on gender referential. We observed that interviewees had their sexual initiation during dating period when they had received no previous orientation concerning sexuality or reproductive health. Some women lived with their partners when pregnancy occurred, even though they considered it to be unexpected. The great majority of them accepted pregnancy, and there were also unions, even if they were not legalized, of many couple who did not lived together. There were reports of abortion attempts when the partner did not accept the pregnancy immediately. Gender questions are present in conjugal relations, with the partners figuring as family providers and women dependent on them, focused on domestic environment, taking the responsible by home, kids and partner's care. Men acted freely, maintaining extra-conjugal relations and hitting their wives at home. Although resentful with their partner's attitude, they maintained the relation. The interviews made explicit the lamentation with the lost of freedom, working and studying opportunities when assuming maternity. On the other hand, they emphasized their non-regret for taking their pregnancy till the end. This way, their daily living seems to be centered on their kids caring and they are conscious that they are the main responsible by them, turning their projects of life for this care. These mothers' lives are marked by inequality, social, economical, cultural and gender conditions in which they live. This way, despite their manifested desire, they find few objective opportunities of breaking with life context in which they are inserted.
\end{abstract}

Keywords: Pregnancy in adolescence. Reproductive Health. Women's Health. Reproductive Behavior. Gender Identity. Feminism. 


\section{RESUMEN}

TRINDADE, R.F.C. Entre el sueño y la realidad: la maternidad en la adolescencia bajo la óptica de un grupo de mujeres de la periferia de la ciudad de MaceióAlagoas, Brazil. 2005. 212 f. Tesis (Doctorado) - Escuela de Enfermería de Ribeirão Preto. Universidad de São Paulo. Ribeirão Preto, 2005.

Este fue un estudio cualitativo, que tuvo como objetivo comprender, a partir de la experiencia de mujeres que se hicieron madres en la adolescencia, el significado de la maternidad en sus contexto de vida. Participaron 14 mujeres entre 20 y 24 años, residentes en la periferia de Maceió, capital del Estado de Alagoas. La recolección de información fue realizada por medio de encuestas, utilizando la historia oral temática como procedimiento metodológico. Fueron construidas narrativas, a partir de las historias de las mujeres y luego, analizadas de acuerdo con el referencial de género. Observamos que las encuestadas tuvieron su iniciación sexual durante el periodo de enamoro cuando no recibieron orientaciones anteriores acerca de sexualidad o salud reproductiva. Algunas mujeres convivían con sus compañeros cuando se embarazaron, pero, aún así, consideraron este un facto inesperado. Hubo aceptación del embarazo por la mayoría de ellas y incluso con la unión, aún que no de manera legalizada, de muchas parejas que no vivían juntas. Tentativas de aborto, cuando los compañeros no aceptaban el embarazo de inmediato, fueron relatadas. Las cuestiones de género se muestran presentes en las relaciones matrimoniales, con los compañeros figurando como proveedores de la familia y las mantenidas mujeres bajo su dependencia, centradas en el ambiente doméstico, asumiendo la responsabilidad sobre el cuidado del hogar, de los hijos y del compañero. Los hombres actúan más libremente, manteniendo relaciones extra-matrimoniales y agrediendo a sus mujeres en casa. A pesar de resentidas con esta actitud de los compañeros, ellas mantenían la relación con ellos. Las encuestadas dejaron explícito que lamentaban la pérdida de la libertad, del ocio, de la oportunidad de trabajo y del estudio para asumir la maternidad. Por otro lado, enfatizaron no tener arrepentimiento por llevar a cabo el embarazo. De esta manera, el cotidiano de esas mujeres parece centralizado en el cuidar de los hijos, conscientes de que son ellas las responsables por ellos, volviendo todos sus proyectos de vida para este cuidado. La vida de estas madres es marcada por las condiciones de desigualdad en las que viven: sociales, económicas, culturales y de género. De esa forma, a pesar de sus deseos manifiestos, ellas encuentran pocas oportunidades objetivas de romper con el contexto de vida en que están inseridas.

Palabras-Clave: Embarazo en Adolescencia. Salud Reproductiva. Salud de las Mujeres. Conducta Reproductiva. Feminismo. 


\section{LISTA DE ILUSTRAÇÕES}

Figura 01. Unidade de Saúde da Família Frei Damião

Figura 02. Conjunto Frei Damião

Figura 03. Poço artesiano do conjunto Frei Damião. Maceió/Al

Figura 04. Área verde do conjunto Frei Damião, início de uma grota

Figura 05. Rua do Conjunto Frei Damião 


\section{SUMÁRIO}

$\begin{array}{ll}\text { APRESENTAÇÃOO } & 15\end{array}$

1 INTRODUÇÃO 17

2 CONSTRUÇÃO DO OBJETO DE PESQUISA 24

$\begin{array}{lll}2.1 & \text { OBJETIVO }\end{array}$

3 ADOLESCÊNCIA

3.1 ADOLESCÊNCIA UM PERÍODO DE TRANSIÇÃO 27

3.2 REPRODUÇÃO NA ADOLESCÊNCIA 32

4 OS DIREITOS REPRODUTIVOS

4.1 SAÚDE REPRODUTIVA E O MOVIMENTO DE MULHERES 40

4.2 MATERNIDADE E GÊNERO

5 REFERENCIAL TEÓRICO-METODOLÓGICO

5.1CONCEPÇÕES SOBRE GÊNERO 52

5.2 PERCURSO DO MÉTODO

6 ANÁLISE DAS NARRATIVAS 80

6.1 IDENTIFICANDO AS MULHERES 82

6.2 CONHECENDO AS MULHERES ESTUDADAS 90

6.3 EVIDENCIANDO AS HISTÓRIAS DA MATERNIDADE NA ADOLESCÊNCIA 
APÊNDICE

A - ETIQUETA DAS FITAS 182

B - TERMO DE CONSENTIMENTO LIVRE E ESCLARECIDO

C - ESBOÇO DAS HISTÓRIAS NARRADAS

ANEXO

A - APROVAÇÃO NO COMITÊ DE ÉTICA EM PESQUISA DA EERP/USP 


\section{APRESENTAÇÃO}

Nosso interesse pelo tema gravidez na adolescência se iniciou a partir da experiência profissional no atendimento a mulheres em uma Unidade de Saúde da Família da Secretaria Municipal de Saúde de Maceió que, no período de 1997 a 2001, esteve sob a gerência do Pólo de Capacitação em Saúde da Família de Alagoas. Um colega médico e eu, professores da Universidade Federal de Alagoas, exercíamos atividades de extensão universitária, na função de médico e de enfermeira do Programa Saúde da Família - PSF, onde desenvolvíamos, entre outras atividades, a consulta pré-natal às gestantes que foram cadastradas pelos agentes de saúde.

O trabalho de atendimento na unidade de saúde permitiu uma aproximação e familiarização com as pessoas desta comunidade, assim como uma aproximação empática com as mulheres, o que nos levou a querer aprofundar a compreensão sobre a gravidez na adolescência.

Os três anos de trabalho, com mães e gestantes, nos deram a oportunidade de realizar várias observações e vivenciar diversas situações no consultório ou nas visitas domiciliares, que nos incitaram inquietações sobre a gravidez na adolescência e nos impulsionaram a investigar acerca desta temática e seu reflexo naquele grupo social. Tivemos a oportunidade de, em nossa dissertação de mestrado defendida em 2000 na EERP/USP, aprofundar os estudos com as mulheres residentes naquela área, focalizando a questão da saúde reprodutiva, adolescência e gravidez na adolescência. Participaram da investigação mulheres que estiveram grávidas em 1999, cadastradas na unidade de saúde do PSF em que havíamos atuado.

O trabalho de pesquisa desenvolvido no mestrado serviu como uma segunda etapa para o desenho da presente investigação, pois forneceu condições de contextualizar melhor o meio sociocultural deste grupo, mais especificamente das mulheres gestantes, e a partir daí identificar novas situações a serem exploradas e explicadas. 
Asim sendo, esta tese é uma contribuição aos estudos de gênero, na medida em que a maternidade na adolescência inclui situações que estão além do fato biológico e da oferta de serviços de saúde reprodutiva para adolescentes.

Acreditamos que despertar a consciência para a importância da maternidade na adolescência em um grupo social mais desfavorecido, dando visibilidade às experiências vividas por estas mulheres e às conseqüências resultantes da mesma, propiciará uma mudança no olhar a adolescente grávida ou a jovem mãe, oferecendo recursos para melhor atender às necessidades deste grupo e como conseqüência melhorar a qualidade da atenção de enfermagem.

Buscamos, através das indagações feitas, analisar a construção social da maternidade na adolescência como elemento central e constitutivo da organização e reprodução das características das identidades sexuais femininas e masculinas, realizada com um grupo de mulheres de 20 a 24 anos que passaram pela experiência de serem mães na adolescência, residentes na periferia da cidade de Maceió. No próximo capítulo, iniciamos com a introdução sobre o tema e nosso interesse em estudá-lo. A seguir expomos sobre o objeto e o objetivo deste estudo.

No terceiro capítulo, trazemos um recorte acerca da adolescência e da gravidez na adolescência. O quarto capítulo traz uma abordagem sobre saúde reprodutiva e maternidade, além de expor sobre estes temas, procuramos explicar a posição que cada um deles mantém com as situações sociais e de gênero. No quinto capítulo, apresentamos a trajetória teórica e metodológica relacionada com o objeto deste estudo. Nesse capítulo, se transmitem as concepções de gênero, considerando que a identidade de gênero é uma construção social, assim como expomos sobre o procedimento metodológico utilizado para operacionalizar esta investigação. Tendo em vista a natureza da investigação, optamos pela pesquisa qualitativa e pelo método da história oral temática.

No sexto capítulo, oferecemos uma visão da interpretação dessas narrativas através de categorias de análise, buscando contextualizar e compreender o modo como a vivência da gravidez e da maternidade na adolescência se deu neste grupo de mulheres. Em continuidade, apresentamos as considerações finais desta investigação. 


\section{INTRODUÇÃO}

Trabalhando na comunidade atendida pelo núcleo do PSF do Pólo de Capacitação em Saúde da famíla de Alagoas, iniciamos nosso contato com o grupo de gestantes, várias ainda na adolescência. Algumas dessas gestantes adolescentes eram primigestas, outras já se encontravam na segunda ou terceira gravidez, e as razões apresentadas por elas foram: desconhecimento sobre o uso de métodos contraceptivos; os efeitos colaterais do anticoncepcional oral; a não-aceitação do uso do preservativo masculino, assim como falta de opção na disponibilidade de métodos oferecidos pela unidade de saúde.

Compreender melhor o significado da gravidez na vida daquelas mulheres adolescentes, ou reconhecer que aquelas jovens grávidas mereciam uma atenção diferenciada, foram elementos norteadores e estimuladores para estudos acerca da temática.

No período em que estivemos atuando na unidade, fomos percebendo que a gravidez na adolescência se apresentava de uma maneira constante. Os indicadores não mostravam alterações, assim como também não refletiam todas as questões que envolviam aquela situação.

Outro ponto observado era a baixa freqüência dos adolescentes da comunidade na unidade de saúde. A busca do serviço acontecia apenas quando eles apresentavam algum problema clínico. Nós não havíamos organizado nenhuma atividade educativa ou preventiva que gerasse uma nova forma de demanda, e não houve sucesso quando foi proposta a formação de um grupo de adolescentes, com o objetivo de orientar sobre as questões relativas à sexualidade.

Observamos que nenhum programa específico com adolescentes fazia parte da proposta de programação do PSF. Quanto às informações em saúde sobre a atenção ao adolescente, o Sistema de Informação da Atenção Básica (SIAB) limita-se a dados sobre a freqüência de gestantes com menos de 20 anos de idade. Dados sobre paternidade não 
constam do SIAB, mostrando que a gravidez é entendida como sendo de responsabilidade exclusiva da mulher e os serviços de saúde, na maioria das vezes, também ignoram a participação masculina.

A informação solicitada no SIAB representa o número de adolescentes grávidas em um determinado período de tempo, não levando em consideração a reincidência dessa condição e perdendo-se a possibilidade de analisar a história reprodutiva dessas adolescentes que poderiam estar em uma segunda ou terceira gravidez. As gestantes acima dos 20 anos, que haviam tido a sua primeira gravidez na adolescência, não eram identificadas como gestantes adolescentes, o que obscurecia o panorama das mulheres que iniciavam sua vida reprodutiva na adolescência.

Foi possível observar, ainda, na comunidade em que trabalhamos, que o fato de a adolescente se descobrir grávida, mesmo quando a gravidez não era planejada, não era uma situação rejeitada, mas aceita com uma certa passividade, algumas vezes como resultado de um namoro ou de uma união precoce. Verificávamos que, na maioria das vezes, era sempre a mulher quem buscava a unidade de saúde, para ser atendida durante a gravidez. O parceiro raramente estava presente, mesmo quando, segundo informações fornecidas pelas gestantes, a gravidez era aceita por ambos. Esta situação dificultava a compreensão de como os homens pensam a respeito destas gravidezes, apesar do fato de que todas as gestantes afirmavam o compromisso dos companheiros em relação à gravidez.

Podemos exemplificar a situação da gravidez na adolescência nesta comunidade com uma situação encontrada: ao iniciar o processo de cadastramento das famílias, em abril de 1997, na segunda casa que visitamos, encontramos uma adolescente, com 17 anos de idade, vivendo em união consensual, cuidando do filho e do domicílio. Essa jovem encontrava-se grávida no terceiro trimestre de gestação e já tinha uma filha com pouco mais de um ano de vida. Até aquele momento não havia recebido nenhum atendimento pré-natal. Posteriormente, fez duas consultas na unidade e recebeu uma visita domiciliar. Não realizou os exames solicitados devido à falta de dinheiro para se deslocar ao laboratório. Em junho deu à luz uma criança, saudável, pesando $3 \mathrm{~kg}$ e 670 gramas e assim, aos 17 anos de idade, sua vida estava organizada como esposa, mãe de dois filhos e dona de casa.

Esse fato demonstra a não-acessibilidade das mulheres aos serviços de saúde, assim como a dificuldade de aderir às recomendações solicitadas devido às questões econômicas 
em que estão inseridas, realçando as ações que lhes garantam cuidados adequados durante a gravidez, pois de acordo com a Conferência de Beijing de 1995 as mulheres têm direito de receber serviços adequados de atenção à saúde reprodutiva que permitam a gravidez e, partos sem riscos e que possibilitem aos casais de terem filhos sadios.

Outra situação que recordamos ocorreu em um atendimento domiciliar, visando a prestar assistência a uma jovem puérpera, que se apresentava com mastite, razão de nossa visita. Ela engravidou aos 12 anos e aos 13 anos de idade já era mãe, morava com o pai de seu filho na casa de sua sogra. Fez as consultas pré-natais dentro do preconizado pelo Ministério da Saúde (MS), não apresentando nenhum problema obstétrico no decorrer de sua gravidez ou parto. Naquela ocasião conheci sua mãe e sua sogra, as quais durante o atendimento interferiam, constantemente, uma de maneira favorável e a outra não, nas orientações e cuidados que estavam sendo prestados, de modo que a jovem ficava dividida entre as duas e as orientações do serviço de saúde, mas preocupada em cuidar do filho e, apesar da mastite, não suspendeu o aleitamento materno.

A adolescência, fase em que estas gravidezes ocorreram, é vista como um período de desenvolvimento entre a infância e a idade adulta, com marcantes modificações biológicas, psicológicas e sociais. É a época do despertar da sexualidade, momento da procura da independência e da difícil familiarização com o próprio corpo (BRASIL/MS, 1996).

O que também pudemos observar, de uma maneira empírica, é que a adolescência para esse grupo social apresentava algumas características diferentes da concepção social e cultural aceitas atualmente. Na maioria das vezes estas meninas passavam por um período de preparação em cuidados domésticos, como ajudar ou assumir a responsabilidade de cuidar da casa ou dos irmãos menores ou de parentes próximos, e isso dava a elas outra disposição e modo de ver a vida. Quanto à escola, a maioria encontrava-se aquém da progressão escolar esperada para essa faixa etária, ou seja, a relação idade e anos de estudo não era compatível com o esperado.

Traverso-Yépez e Pinheiro (2002), em trabalho de pesquisa-intervenção realizado em um bairro da periferia de Natal $(\mathrm{RN})$, sobre o contexto de vida dos adolescentes, chegaram a algumas considerações que indicam que se deve falar de adolescências (no plural), caracterizando que cada vivência nesta etapa de vida em particular irá depender de 
variáveis sociodemográficas tais como gênero, classe social e contexto histórico-cultural, além das diferenças de classe, de local de moradia e da geração a que eles pertencem.

Rosalvo (1979) sugere que a desigualdade universal dos papéis sexuais provavelmente seja o resultado de um conjunto de diferentes fatores, envolvidos no estabelecimento das sociedades. Para a autora, parece que uma "análise das forças nos sistemas sociais humanos e da organização das famílias humanas, em particular, propiciará resultados muito promissores" (ROSALVO, 1979 p. 39) no entendimento e busca de superação das desigualdades.

Em muitas sociedades, ditas tradicionais, uma grande parte da vida adulta da mulher é gasta na geração e criação dos filhos. Isso leva à diferenciação das dimensões doméstica e pública, sendo suas atividades restritas aos cuidados com os filhos e o enfoque de suas emoções e a atenção são voltados para os filhos e o lar, sendo as mulheres absorvidas principalmente em atividades domésticas devido a este papel (ROSALVO, 1979).

No estudo, realizado para o mestrado, pudemos identificar a partir de qual idade em que as mulheres desta área iniciam sua vida reprodutiva. Das 274 mulheres grávidas que foram cadastradas pelo PSF, em 1999, em 251 encontramos a idade da ocorrência da primeira gravidez, nas informações dos prontuários e entrevistas. Destas, 197 (78,5\%) engravidaram quando adolescentes, com idade entre 12 e 19 anos, e 54 (21,5\%) após a adolescência, com idade entre 20 e 30 anos. Daquelas em que constava a idade da ocorrência de primeira gravidez, apenas 72 (26,6\%) eram primigestas. Destas, 53 (72,6\%) eram adolescentes e 19 (26,0\%) não-adolescentes, demonstrando que a vida reprodutiva tem se iniciado, com maior freqüência, em mulheres com idade inferior aos 20 anos (TRINDADE, 2001; TRINDADE e ALMEIDA, 2004).

Neste estudo, pudemos verificar que a escolaridade entre estas mulheres é baixa. Das mulheres que engravidaram com idade inferior a 20 anos, encontramos uma variação de 0 a 12 anos de estudo, destas 30,0\% eram analfabetas e 29,6\% tinham de 1 a 4 anos de estudo, ou seja, eram analfabetas funcionais. Entre aquelas que engravidaram com mais de 20 anos, a variação dos anos de estudo foi de 0 a 15 anos, sendo que 25,0\% também eram analfabetas (TRINDADE, 2001).

A tabela 1 apresenta o resultado do censo de 2000 do IBGE sobre a relação entre filhos tidos e anos de estudo em Alagoas. Nela pode-se observar em todas as faixas de 
idade que o número de mulheres que teve filhos diminui conforme aumenta o número de anos de estudo, sendo a redução mais acentuada na faixa de 15 a 19 anos. Porém na faixa de 10 a 14 anos não se observa o mesmo fato, pois um número maior de anos de estudo correspondeu a um aumento da ocorrência de nascimentos (IBGE, 2000). Esse dado aponta para a necessidade de aprofundar estudos visando a compreender esse fenômeno nessa faixa de idade.

Tabela 1 - Distribuição percentual de mulheres de 10 anos a 49 anos de idade que tiveram filhos, segundo os grupos de anos de estudo e os grupos de idade das mulheres - Alagoas, 2000.

\begin{tabular}{ccccccc}
\hline $\begin{array}{c}\text { Grupos de anos } \\
\text { de estudo } \\
\text { e grupos de idade } \\
\text { das mulheres }\end{array}$ & $\begin{array}{c}\text { Sem instrução e } \\
\text { menos de } 1 \text { ano } \\
\%\end{array}$ & $\begin{array}{c}1 \text { a } 3 \\
\text { anos } \\
\%\end{array}$ & $\begin{array}{c}4 \text { a } 7 \\
\text { anos } \\
\%\end{array}$ & $\begin{array}{c}8 \text { a } 10 \\
\text { anos } \\
\%\end{array}$ & $\begin{array}{c}11 \text { a } 14 \\
\text { anos } \\
\%\end{array}$ & $\begin{array}{c}\text { não } \\
\text { determinado } \\
\%\end{array}$ \\
\hline Total & 78,64 & 53,59 & 52,31 & 49,58 & 59,64 & 72,96 \\
10 a 14 anos & 1,16 & 0,48 & 0,56 & 2,33 & - & 2,04 \\
15 a 19 anos & 30,89 & 24,62 & 16,21 & 7,99 & 8,64 & 22,92 \\
20 a 24 anos & 70,59 & 71,29 & 62,84 & 35,78 & 24,54 & 57,29 \\
25 a 29 anos & 83,60 & 85,11 & 82,30 & 69,04 & 52,60 & 78,54 \\
30 a 34 anos & 89,28 & 91,22 & 88,90 & 85,42 & 73,15 & 87,38 \\
35 a 39 anos & 91,15 & 92,90 & 92,26 & 88,15 & 82,10 & 92,31 \\
40 a 44 anos & 93,39 & 94,86 & 93,19 & 91,79 & 84,66 & 92,73 \\
45 a 49 anos & 93,23 & 92,71 & 93,46 & 94,36 & 86,34 & 92,42 \\
\hline
\end{tabular}

Fonte: IGBE

Acreditamos que maternidade na adolescência nesta comunidade não é uma situação individual, mas sim um aspecto social. Recordamos de uma menina de 13 anos que procurava freqüentemente a unidade. Ela morava com o namorado na casa dos pais, freqüentava a escola, mas ainda não havia concluído os quatros anos do estudo fundamental; em uma progressão escolar regular estaria cursando a $7^{\text {a }}$ série. Por diversas vezes foi ao ambulatório por suspeitar de que estava grávida. Ao se referir a sua suspeita disse: "conversando com outras mulheres, elas sentiam o que eu estou sentindo". Esta frase mostra sua identificação como mulher. Vivendo com o namorado se sentia como uma esposa. A maternidade poderia confirmar sua posição social.

Ela apresentou uma doença sexualmente transmissível - DST, mostrando a falta de conhecimento sobre as questões sexuais, colocando em risco sua saúde e a própria vida reprodutiva futura. Em seguida, ela passou a coabitar com outro namorado. Tal fato nos 
mostra a fragilidade destas relações construídas ainda na adolescência, com rompimentos e novas uniões. Entretanto essa fragilidade das relações não pode ser definida como um problema de união entre os adolescentes, pois acontecem em todas as faixas etárias. A particularidade é que a repercussão em idades muito jovens pode comprometer a saúde emocional, pois a adolescência também é caracterizada por transformações psicológicas e decisões tomadas nesta fase poderão repercutir em toda a sua vida futura.

Assim com base nas experiências, observações feitas e pesquisa realizada, acerca da gravidez e maternidade na adolescência, existem algumas perguntas que fazemos, sobre este grupo populacional, para melhor compreender sua realidade:

- A gravidez e a maternidade na adolescência constituem problemas para um grupo de mulheres residente na periferia de Maceió?

- Em que circunstâncias engravidar e ser mãe na adolescência interfere nos projetos de vida desta mulher ou a maternidade faz parte de seu projeto de vida?

- Qual a relação que essas mulheres estabeleceram com os pais dos filhos tidos na adolescência?

Acreditamos ser necessário compreender como esta mulher que iniciou sua vida reprodutiva na adolescência se define enquanto sujeito social dentro do seu contexto de vida, para que possamos entender como as relações de poder em que elas vivem favoreceram uma diferenciação de papéis entre homens e mulheres, no que diz respeito à maternidade na adolescência e aos espaços de relação entre a esfera privada e a pública, possibilitando interpretar essa construção à luz de gênero e propor modelos de superação da mesma.

Para realizar uma investigação, "é evidente que isolamos certos problemas para serem estudados e que esses problemas constituem pontos de partida ou de entrada para processos complexos. Mas são processos que devemos de ter sempre presentes em mente" (SCOTT, 1995, p.85-86). No que diz respeito à maternidade que acontece na adolescência, não é um fato que se encerra nesta fase, sua influência prossegue em outras etapas tendo uma ação direta na maneira como a vida de mulheres e homens irá se organizar.

Entendemos que os estudos sobre a maternidade na adolescência são importantes e que os mesmos poderão contribuir para a Enfermagem, assim como para outras profissões que trabalham com esta questão, de forma a ampliarmos a compreensão sobre a 
complexidade do seu significado através das experiências sociais, compreendendo as relações de gênero envolvidas, muitas vezes desiguais, que são influenciadas pelas construções sociais onde as pessoas estão inseridas e as relações estabelecidas de poder, acesso à educação, ao mercado de trabalho e a assistência à saúde reprodutiva. 


\section{CONSTRUÇÃO DO OBJETO DE ESTUDO}

Tendo em vista as associações de idéias que desenvolvemos na introdução deste trabalho, a respeito da gravidez na adolescência em uma comunidade periférica, e o desejo de conhecer as trajetórias de vida das mulheres, a temática a que nos propomos a estudar encontra-se vinculada à saúde da mulher, especificamente a gravidez e maternidade na adolescência.

Esta é uma pesquisa centrada na maternidade na adolescência, tendo como objeto de estudo a construção social da maternidade na adolescência na periferia de uma cidade no Nordeste brasileiro.

O objeto deste estudo foi concebido a partir da necessidade de aprofundar o conhecimento sobre a vida de mulheres que foram mães quando adolescentes, a partir da nossa experiência profissional, no atendimento ambulatorial à mulher gestante e à gestante e mãe adolescente e aos estudos realizados para a elaboração da dissertação de mestrado sobre a gravidez na adolescência.

Compreendendo que a maternidade figura no contexto de vida da maioria das mulheres, refletir sobre essa ocorrência em fases precoces da vida nos levou a questionar se a gravidez na adolescência, em mulheres que vivem em uma situação de vida mais desfavorecida social e economicamente, pode estar ligada à antecipação dos acontecimentos na vida destas adolescentes.

A visão das mulheres adultas jovens, que se tornaram mães na adolescência, possibilitará entender como esta ocorrência é compreendida e interpretada por elas, e como a maternidade influenciou suas vidas no processo de amadurecimento, ou seja, na passagem da adolescência para a vida adulta. 
Este estudo foi realizado a partir da experiência de ser mãe ainda na adolescência, em um grupo de mulheres residentes em uma região periférica da cidade de Maceió. Ele poderá fornecer uma aproximação maior com as questões que envolvem a ocorrência da maternidade na adolescência, neste grupo social.

Nesta investigação, buscamos compreender as situações ligadas à vida delas e para tal propomos como questão básica investigar se:

\section{A maternidade fazia parte do projeto de vida de adolescentes da periferia de uma cidade do Nordeste brasileiro?}

Esta temática é importante e atual, visto que assistindo aos adolescentes, e às mulheres grávidas e às mães nesta fase da vida, compete aos profissionais de saúde, independente da área de conhecimento, buscar subsídios que os levem a uma melhor compreensão deste fenômeno, que não é novo, mas que na conjuntura presente tem conseqüências e razões diferentes das de décadas ou séculos anteriores.

A compreensão de que a gravidez na adolescência encontra-se vinculada a diversos sistemas, seja de poder, de política, de geração e de gênero, e dada à arquitetura conceitual dos estudos sobre gravidez na adolescência, é possível definir três níveis interligados de interrogação a respeito da construção deste tema: primeiro aquele que coloca a gravidez como um projeto de vida da adolescente, cujo interesse está na formação de uma família; o segundo é aquele que encara a gravidez na adolescência como um problema, estando esta vinculada a uma maior probabilidade de problemas obstétricos, e o terceiro apresenta uma visão mais social da gravidez na adolescência, identificando-a como um problema e colocando-a como uma das responsáveis pela baixa escolaridade da mulher e sua dificuldade de inserção no mercado de trabalho.

Entre os profissionais de saúde e pesquisadores, existe um predomínio do pensamento de que a gravidez na adolescência é um problema de saúde pública que, deve ser "combatido", mas o que devemos ainda considerar sobre este evento? E o que seria necessário para que se possa abordá-lo de maneira adequada neste grupo social, alvo desta investigação? 
Se a gravidez e a maternidade são um problema, como intervir em sua ocorrência, visto que o percentual de nascidos vivos de mães adolescentes no estado de Alagoas apresenta um aumento em um período de oito anos, passando de 23,90\% em 1994 para 25,92\% em 2001. Da mesma forma, a taxa de fecundidade específica por 100 mulheres de 10 a 19 anos no estado passou de 3,74 em 1994 para 5,19 em 2001. Em Maceió, a taxa de fecundidade específica por 100 mulheres de 10 a 19 anos passou de 5,52 em 1994 para 4,99 em 2001, apresentando uma ligeira queda, mas o mesmo não ocorreu na faixa de idade de 10 a 14, que, em 1994, foi de 0,34 e, em 2001, aumentou para 0,43 (BRASIL, 2004).

\subsection{OBJETIVO}

Nesse sentido, o principal objetivo desta pesquisa encontra-se em:

Compreender o significado da maternidade(s) no contexto de vida de um grupo de mulheres que se tornaram mães na adolescência. 


\section{ADOLESCÊNCIA}

\subsection{ADOLESCÊNCIA UM PERÍODO DE TRANSIÇÃO}

Constatamos que parece existir certo consenso, no meio científico, quanto a ser a adolescência um período de transição, um fenômeno específico dentro do desenvolvimento humano, que se exterioriza dentro do limite sociocultural em que se desenvolve (DESSER, 1993; BRASIL, 1996; OLIVEIRA, 1998).

A adolescência é o período de transição entre a infância e a idade adulta e se caracteriza por: a) os esforços realizados para alcançar objetivos vinculados às expectativas da corrente cultural principal; b) a aceleração do desenvolvimento físico, mental, emocional e social. A maturidade física, ou seja, a puberdade tem seus limites e só estará concluída ao final do crescimento esquelético, com o amadurecimento gonadal, possibilitando ao adolescente a completa execução das funções reprodutivas, ao contrário da maturidade psicológica ou social, que pode variar de acordo com o ambiente sociocultural do indivíduo (OMS, 1986; BRASIL, 1993a).

Efetivamente a adolescência varia enormemente entre uma cultura e outra quanto ao ganho da independência que caracteriza a idade adulta. Esta transição reúne as seguintes características: desenvolvimento biológico desde o começo da puberdade até a completa maturidade sexual e reprodutiva; desenvolvimento psicológico desde os padrões cognitivos e emocionais da infância até os padrões cognitivos da idade adulta; trânsito desde o estado total de dependência socioeconômica da infância a uma independência relativa (OMS, 1986).

Essa passagem não se apresenta da mesma forma para homens e mulheres, apresentando-se com papéis distintos. Para o homem, no que tange às suas experiências e "erros" são denominadas "coisas da idade", porém a mulher na adolescência continua a ser 
treinada e condicionada para assumir seu papel na sociedade, contudo este caminho transcende ao biológico, pois é social, ainda que este social queira chamá-lo de biológico (DESSER, 1993; OLIVEIRA, 1998).

A Organização Mundial da Saúde - OMS $(1986,1989)$ define que a adolescência está compreendida na faixa etária entre 10 e 19 anos de idade e definiu juventude como o período entre 15 e 24 anos cujo período se iniciará na metade da adolescência.

De uma maneira genérica descreve-se que uma gravidez, nesta fase, proporciona uma entrada precoce na vida adulta e um amadurecimento para o qual a adolescente ainda não se encontra preparada para enfrentar (OMS, 1989).

Concordamos com os pesquisadores que consideram arbitrário o corte em anos para adolescência, pois parâmetros rígidos que desconsiderem as características socioculturais, além das físicas nem sempre se aplicam a todas as classes sociais de forma igualitária. Nas classes sociais econômica e culturalmente desfavorecidas, em nossa sociedade, os parâmetros para passagem da adolescência para o mundo dos adultos estão relacionados a “o início da vida sexual ativa, da organização familiar, da inserção no mercado de trabalho ou de outros indicadores sociais que nada têm a ver com indicadores biológicos" (RIOS et al., 2002, p. 51).

A OMS (1986) também acredita que a idade cronológica definida para a adolescência é útil para os processos de padronização, mas é importante reconhecer que são socialmente arbitrárias. De acordo com essa instituição, uma pessoa de 15 anos de idade poderia ser considerada como jovem em uma sociedade, como adulto em outra ou como uma criança em outra.

É provável que em sociedades menos desenvolvidas, o grupo de 15 a 24 anos constitua um importante meio de produção econômica para a família e a sociedade, enquanto em outras sociedades mais desenvolvidas, uma grande parte das pessoas nesta idade dependem de outros membros da sociedade (OMS, 1986).

O Ministério da Saúde, em seu Programa de Atenção à Saúde da Criança e do Adolescente (PROSAD) considera que o adolescente, neste período, vivencia momentos de equilíbrio e de desequilíbrio, sendo esta uma fase da vida caracterizada pelo amadurecimento do aparelho reprodutivo e suas implicações, tais como; mudanças do corpo e transformação da imagem corporal; modificações do sentir a sexualidade 
direcionada para os genitais; modificações da percepção e do pensamento, passando do concreto para o abstrato; variações do humor; modificações das relações sociais (afastamento progressivo da família); reformulação e estabelecimento dos valores éticos, morais e estéticos e estruturação das bases da identidade adulta (BRASIL, 1993a).

Como ocorre com as pessoas de todas as idades, os jovens se defrontam com as experiências da vida e se formam em relação à sociedade em que vivem. A natureza dessa sociedade influi em seu desenvolvimento, sua condição, o modo de sua vida cotidiana, suas aspirações, suas oportunidades e sua saúde, sendo influenciados pela cultura, padrões demográficos, e os padrões socioeconômicos ou sociopolíticos. A vida dos adolescentes é formada e controlada de forma considerável pelo seu ambiente (OMS, 1986).

Outeiral (1994) define a adolescência, fundamentalmente, como um fenômeno e um processo psicológico e social e desta forma ela terá características diferentes influenciadas pelo ambiente social, econômico e cultural em que vive. As mudanças físicas consideram como o fenômeno da puberdade que é um processo biológico que se inicia em nosso meio, entre 9 e 14 anos e que se caracteriza "pelo surgimento de atividade hormonal que desencadeia os chamados caracteres sexuais secundários" (OUTEIRAL, 1994, p. 5).

O significado das transformações corporais, das mudanças na forma de pensar, dos conhecimentos adquiridos pelo adolescente, que acontecem de uma forma individual, tem sido ancorado na psicologia da adolescência, sendo os mesmos influenciados pelas modificações de socialização, que se manifestam nesta fase da vida e irão conduzir à definição de sua identidade individual, (BRASIL, 1993a; 1996).

As mudanças sofridas pelos adolescentes fazem com que esta fase também seja caracterizada por conflitos internos que podem passar pelo desejo das mudanças e pelo medo das perdas ou lutos que elas acarretam (BRASIL, 1993b).

A adolescência, também, é o momento do desenvolvimento da sexualidade, isto é, da evolução sexual, caracterizada pela masturbação, brincadeiras homossexuais, conduzindo a uma aprendizagem exploratória do seu corpo e do corpo do outro. Alguns adolescentes vêem o sexo como algo pouco duradouro, tratando-o de forma superficial, algo temporário, não estabelecendo relacionamentos, pois vive uma época de descobertas e aprendizado.

Para Barroso \& Bruschine (1991) em uma pesquisa executada em 1979, para 
desenvolvimento de um programa de educação sexual para adolescentes, realizado com jovens de 15 a 17 anos de idade da periferia de São Paulo, de colégios públicos e particulares, leigos e religiosos, constataram a existência de uma "dupla moral" sexual que estimula o exercício da sexualidade entre os meninos e a reprime entre as meninas. Apesar de este comportamento estar sendo revisto em alguns centros urbanos, está longe de desaparecer em todas as camadas sociais.

Egypto (1991) também constatou, nesta mesma pesquisa, que a imposição à abstinência sexual para as mulheres antes que se consolide uma vida sexual que seja assumida publicamente, conduz à desinformação quanto à prevenção de uma gravidez por meio do uso de anticoncepcionais o que, aliado à ilegalidade do aborto, gera um conflito emocional na mulher quando se encontra frente a uma gravidez que não foi planejada e que pode, também, não ser desejada.

Os resultados obtidos nesta pesquisa mostram a importância do debate dos papéis sexuais, visto que existe, na sociedade brasileira, uma delimitação dos papéis sociais com origem no sexo. "E a forma de expressão da sexualidade vai depender muito do papel social desempenhado por homens e mulheres" (EGYPTO, A.C.; EGYPTO, M.M., 1991, p. 50), estes papéis sociais são assimilados desde a gestação, quando se demonstra o desejo por um menino ou menina, depois se configura em diferenças nos jogos, nas brincadeiras, a vigilância da família e das instituições. Segundo estes autores, a relação entre os papéis sociais do homem e da mulher, na nossa sociedade, não é de complementariedade e sim de hierarquia.

Estudo sobre as dimensões do problema da gravidez na adolescência constatou que a sociedade espera que os homens pratiquem sexo ao contrário da mulher. Assim, as adolescentes que têm uma vida sexual não autorizada apresentam dificuldades na decisão sobre o uso de anticoncepcionais, pois isto significaria dar-lhes poder sobre sua própria vida. Esta visão social é muitas vezes incorporada pelos serviços de saúde, pois são poucos aqueles que promovem ações de educação sexual para os adolescentes, existindo, também, por parte da adolescente, o medo da família tomar conhecimento sobre o uso de métodos anticoncepcionais e a vergonha de fazer um exame ginecológico (OLIVEIRA, 1998).

Dentro da experiência que tivemos na assistência à mulher na Unidade de Saúde da Família, foi possível constatar que as mulheres dessa comunidade que se encontravam na fase da adolescência haviam passado por um processo de amadurecimento, pois viviam 
diversas situações sociais que as levavam a um processo de amadurecimento, tais como: inserção precoce no trabalho doméstico, remunerado ou não; abandono da escola ou encontrando dificuldades de seguir uma progressão escolar regular; relacionamento sexual precoce que evoluía, muitas vezes, para um casamento formal ou uma união consensual.

Para Pitanguy (2003), os papéis relacionados a gênero afetam homens e mulheres por toda a sua vida, e estes papéis começam a ser definidos na infância com crianças em idade escolar, quando as meninas são forçadas a deixarem a escola ou a combinarem os afazeres domésticos com a sua educação, já os meninos abandonam ou repetem o ano para participarem de atividades geradoras de renda, isto devido aos papéis relacionados ao gênero.

Chodorow (1979), estudando diversas conceitualizações da personalidade feminina e masculina, desenvolveu uma teoria relacionando o comportamento do papel sexual adulto ao fato de que é a mulher quem cria os filhos. A autora apresenta como o envolvimento precoce com a figura feminina possui conseqüências distintas para o desenvolvimento tanto para os meninos como para as meninas. De acordo com seus estudos, "parece provável que desde a primeira infância de seus filhos, mães e mulheres tendem a se identificar mais com as filhas e ajudá-las a se diferenciar menos e aqueles processos de separação e individualização são mais difíceis para as meninas" (CHODOROW, 1979, p. 70).

De acordo com Chodorow (1979), a evidência sociológica sugere que na medida em que uma mãe trata seu filho de maneira diferente, geralmente tem a intenção de enfatizar sua masculinidade em contraposição a si mesma. Enquanto a menina estabelece vínculos com sua mãe e outras mulheres, participa de grupos intergeracionais e traça seu papel sexual e de gênero de uma forma que parece fácil e natural, mediados por uma real dependência das relações afetivas. O menino freqüentemente define sua masculinidade, através de grupos de companheiros do mesmo sexo e da mesma idade, pois o papel masculino do pai geralmente é desempenhado longe de casa, assim sendo, essa identificação de gênero masculino do menino é "posicional, com os aspectos do papel masculino do seu pai claramente definidos ou não [...] ao invés de uma identificação pessoal mais generalizada [...] que poderia surgir de um relacionamento real com seu pai" (CHODOROW, 1979, p. 72).

No processo de desenvolvimento do feminino e do masculino, são percorridos 
caminhos distintos, a mãe tende a tratar diferentemente as crianças de acordo com seu sexo. A sua mãe que é uma mulher não desenvolve apenas um papel definido rigidamente, ela terá a tendência a tratar as crianças de sexos diferentes de modo diverso um do outro, pois se identificará mais com a filha, podendo transferir suas expectativas e experiências para ela. Dessa forma, a menina estabelece uma identificação com sua mãe, com a maternidade e dessa forma com o ser mulher (CHODOROW, 1979).

Dentro da sua classe social ou do contexto social em que vivem, meninos e meninas vivenciam estas relações de modo distinto, sendo educados para desempenharem papéis específicos de acordo com o seu sexo. Segundo Vitielo (1986), antes as meninas eram pressionadas pela moral social a chegarem virgens ao matrimônio, atualmente existe uma pressão em contrário, o grupo social a estimula a ter relações sexuais, chegando a virgem a ser considerada quase como uma anormal.

\subsection{REPRODUÇÃO NA ADOLESCÊNCIA}

A maioria dos estudos acerca da gravidez na adolescência é de caráter demográfico, psicossocial e epidemiológico com foco centrado nas mulheres, o que reforça a pouca visibilidade social do parceiro masculino no desempenho da reprodução.

A gravidez na adolescência está diretamente ligada à iniciação sexual dos jovens, apesar da existência de estímulos sexuais, que são oriundos de diversas fontes, seja na propaganda, novelas de televisão com as imagens românticas de casais jovens, música e até nas danças mais populares. Existe uma contradição social, que é a desinformação quanto à sexualidade e ao uso de anticoncepcionais, o que poderá acarretar danos físicos, psicológicos e sociais quando o início da vida sexual é precoce, podendo ocorrer, entre outros, uma gravidez não planejada assim como expor os jovens às DSTs.

A ONU (1995) em seu informe sobre a Conferência de Beijing afirma que as adolescentes necessitam ter acesso a serviços de saúde e nutrição durante seu crescimento. Constatou-se, nesta conferência, que o assessoramento e o acesso à informação e aos

serviços de saúde sexual e reprodutiva dos adolescentes continuam insuficientes ou inexistentes e do ponto de vista biológico e psicológico, as adolescentes são mais vulneráveis que os homens ao abuso sexual, à violência e às conseqüências das relações 
sexuais prematuras e sem proteção. A tendência a ter experiências sexuais em idade precoce, somada à falta de informação e disponibilidade de serviços de atenção à saúde, aumenta o risco de uma gravidez não desejada.

As relações de gênero interferem na iniciação sexual e esta se realiza mais precocemente entre os homens do que entre as mulheres. A mulher, apesar de se mostrar interessada na atividade sexual, esta "se apresenta como uma dádiva que é concedida ao homem, sempre ofertada a partir da insistência dele" (HEILBORN et al., 2000, p.2).

No mundo atual, em que os estímulos e apelos sexuais estão por toda a parte, a iniciação sexual tem acontecido cada vez mais precocemente, em todos os níveis da sociedade, em um contexto diferente daquele que acontecia através do matrimônio com a menina de 12 a 14 anos de idade na época do Brasil Colônia.

$\mathrm{Na}$ literatura, existe uma variação para a idade da iniciação sexual, de 14,9 a 19,5 anos de idade (BRUNO; BAYLEY, 1998; FERRAZ; FERREIRA, 1998). No grupo de mulheres estudadas, nesta comunidade da periferia de Maceió, a média de idade da iniciação sexual da mulher foi de 16 anos com uma mediana de 15 anos de idade, sendo que $91,1 \%$ das mulheres tiveram sua primeira relação sexual antes de completar 20 anos de idade e em $35,1 \%$ essa relação aconteceu entre a idade de 10 e 14 anos (TRINDADE, 2001).

No que concerne ao casamento, Heilborn $(1998,2002)$ parte do princípio de que a perda da virgindade que, no passado, tinha um caráter de garantia de um compromisso, de se estabelecer a partir desta perda uma união, atualmente, com a mudança de visão sobre sua importância, essa perda não tem o mesmo valor, fazendo com que a gravidez passe a ser utilizada como uma estratégia de estabelecimento de aliança. A gravidez na adolescência pode estar vinculada a uma nova maneira dos jovens se relacionarem atualmente, com "o aparecimento do sistema ficar/namorar em substituição ao modelo mais tradicional [...] do namoro/casamento" (HEILBORN, 1998, p. 30).

Bozon (1998) reconhece que as trajetórias conjugais vêm sofrendo modificações ao longo da história e que o papel da mulher também está se transformando e, sendo assim, é de se esperar uma modificação em sua sexualidade. Um outro aspecto importante relativo à sexualidade é citado por Loyola (1998, p. 43), quando afirma que sexualidade pode ser relacionada com "[...] sentimentos, mais especificamente com os sentimentos associados às idéias de amor e paixão, igualmente ligados ao sexo e à reprodução [...]”. 
Nessa transformação, os relacionamentos sexuais podem ser classificados segundo o tipo de ligação que o casal ou parceiros apresentam, assim temos relação de casal, aventura de uma noite, "o ficar" dos adolescentes (neste poderá ou não estar incluída a relação sexual), relação estável, relação ocasional com o mesmo parceiro, sendo que nestes relacionamentos nem sempre estão claras as questões relativas à saúde reprodutiva, pois o direito ao livre exercício da sexualidade nem sempre vem acompanhado de uma educação sexual, o que poderia dar mais poder e segurança para o seu desenvolvimento.

Outro fator relacionado é que a visibilidade da gravidez precoce com uma configuração problematizadora pode ser em decorrência de ser vivenciada, com freqüência, fora do contexto matrimonial; e principalmente nas camadas sociais desfavorecidas. Esse fato gera um aumento da demanda para o Estado, no que diz respeito às políticas públicas de saúde e atendimento assim como reforça e agrava os problemas sociais, o que "acaba reproduzindo uma visão conservadora e parcial da sexualidade do adolescente" (TORRES, 2002, p. 52).

A Conferência de Beijing (1995) constata que a maternidade prematura segue sendo um obstáculo para o progresso educacional, econômico e social da mulher em todo o mundo e que o casamento e a maternidade prematuros podem reduzir drasticamente as oportunidades de educação, emprego para as jovens e provavelmente, prejudicar em longo prazo a sua qualidade de vida e a dos seus filhos (ONU, 1995).

Pesquisas desenvolvidas nas décadas de 1980 e 1990 no Brasil indicavam de forma clara que as mulheres desejavam ter menos filhos e buscavam para isso a contracepção. Os resultados apontavam que elas apresentavam conflitos entre o significado que a maternidade tem em suas vidas e o desejo de aderir a práticas contraceptivas, porém o uso deles, longe de permitir a separação entre a sexualidade e a maternidade, representava o desejo de limitar o número de filhos, para cuidar melhor deles, "correspondendo de forma mais adequada ao papel feminino de atender às necessidades afetivas e materiais das crianças" (ARILHA, 1999a, p. 6). A autora constatou que, apesar da escolha de limitar o número de filhos, não era freqüente que esta contracepção aumentasse as possibilidades delas se inserirem no mercado de trabalho.

Berquó (1999) ressalta o fato de não ser válido supor que ter um número menor de filhos ampliará as oportunidades de trabalho para as mulheres. Equivale, então, dizer que a contracepção nem sempre representa uma forma de empowerment, ou seja, de dar poder 
para as mulheres, a fim de que as mesmas possam se desenvolver nas esferas da educação, na conquista do mercado de trabalho, na participação social e política, com total controle da sexualidade e da saúde reprodutiva.

Para Berquó (1998), a juventude representa um momento da vida cheio de expectativas por parte da sociedade e da família, sendo que as gravidezes que ocorrem, sendo desejadas ou não, podem mudar o rumo das vidas dessas jovens, levando muitas vezes a uniões precoces, legalizadas ou não.

Os adolescentes sexualmente ativos requerem informações, orientações e serviços especiais em matéria de planejamento familiar, e as adolescentes que ficam grávidas necessitam de apoio especial de suas famílias e da comunidade durante a gravidez como também para os cuidados com os filhos (ELÓSEGUI, 2002).

Maternidade e adolescência são duas situações distintas, sendo importante identificar o que elas podem significar na vida de mulheres e de homens e quais as mudanças relacionadas a estes eventos. Assim sendo, buscamos compreender melhor o que a maternidade neste momento pode representar à vida futura da adolescente, pois é a junção de dois momentos que gera transformações na vida de uma pessoa, ou seja, a adolescência e a maternidade, o que não significa dizer que estas experiências sejam um problema para quem as está vivenciando, pois irá depender das circunstâncias em que elas ocorrem

Constatamos que a gravidez e a maternidade de mulheres adolescentes são experiências distintas, de acordo com a classe social. Em classes sociais populares, a falta de perspectiva em relação à vida torna a gravidez e a maternidade um projeto de vida (GUIMARÃES, 2001).

Para Heiborn (2002, p. 83), “a maternidade da adolescente aparece como uma possibilidade de mudança de status no interior da família de origem, pois, em alguns contextos, a maternidade confere à moça um certo tipo de autoridade diante dos pais".

No estudo realizado com mulheres desse grupo social que estavam grávidas em 1999, encontramos que 35,2\% eram adolescentes, sendo que 3,0\% delas tinham idade entre 13 e 14 anos e $32,2 \%$ entre 15 e 19 anos, destas, 80,8\% eram casadas ou viviam em união consensual (TRINDADE, 2001). 
Quanto à idade de início da vida reprodutiva, observou-se que 65,3\% das mulheres tiveram sua primeira gravidez entre os 15 e 19 anos de idade, fase em que a Organização Pan-Americana de Saúde - OPAS define como a adolescência propriamente dita, e 13,1\% tiveram esta gravidez entre 12 e 14 anos de idade, ou seja, na pré-adolescência (TRINDADE, 2001).

Dados do censo de 2000 demonstram que, do total de adolescentes de Alagoas, 12,43\% viviam em companhia de cônjuge ou companheiro (a). Constata-se também que, em Alagoas, 63,93\% de mulheres com 10 anos ou mais de idade com filhos tidos viviam ou já viveram em companhia de cônjuge ou companheiro, sendo que entre as adolescentes este percentual era de $95,60 \%$ para as mulheres de 10 a 14 anos e de $91,93 \%$ para as de 15 a 19 anos, evidenciando a precocidade na constituição de famílias, nesta faixa de idade, geradas ou não pela maternidade (IBGE, 2000).

Aquino et al. (2003) realizaram um estudo multicêntrico, sobre adolescência e reprodução no Brasil, em três capitais de regiões distintas, tendo sido entrevistados 4.634 jovens com idade entre 15 e 24 anos. As pesquisadoras chegaram aos seguintes resultados: entre aqueles que já haviam iniciado a vida sexual, 33,4\% das mulheres e $22,4 \%$ dos homens relataram terem tido a experiência de engravidar na adolescência antes dos 20 anos de idade, destacando-se a capital Salvador (representando a região Nordeste) com as maiores taxas com $37,8 \%$ das mulheres e $26,0 \%$ dos homens.

O resultado do SINASC, de 2001, para Alagoas e para Maceió, especificamente, mostra que, do total de nascidos vivos, $24,8 \%$ e $24,5 \%$, respectivamente, eram de mães com idades entre 15 e 19 anos e 1\% foi de mães com idade entre 10 e 14 anos. Estes dados variaram, entre as grandes regiões brasileiras, apresentando o seguinte percentual de distribuição para o Brasil e regiões, para as faixas de idade de 10 a 14 anos e de 15 a 19 anos respectivamente: Brasil, 09\% e 22,4\%; Norte, 1,4\% e 28,9\%; Nordeste 1,1\% e 24,8\%; Sudeste, $0,6 \%$ e 19,2\%; Sul, 0,8\% e 20,3\%; Centro-Oeste 1,0\% e 24,4\%. A região Sudeste seguida da região Sul apresentaram os menores índices (BRASIL, 2004).

Com a idade de 15 a 16 anos, espera-se que a menina já tenha desenvolvido a compreensão sobre o corpo e esteja também desenvolvendo um projeto de vida, podendo a maternidade fazer parte deste projeto para a maioria dessas mulheres que engravidaram na adolescência (TRINDADE, 2001). Esses dados reforçam nossas indagações quanto à adolescência ser vivenciada de forma diferente neste grupo social, pois frente às condições 
de vida em que estavam inseridas, a baixa escolaridade associada a uma falta de orientação e não-qualificação profissional, essas jovens não apresentavam projetos de vida concretos de inserção no mundo do trabalho, ou mesmo ações com vista à efetivação de algum desejo.

Concordamos com Catharino e Giffin (2002, p. 7) que acreditam que o advento da gravidez na adolescência em um grupo excluído socialmente poderia representar a tentativa dessas jovens de encontrar um lugar social - "ser mãe para estas meninas, talvez seja uma das poucas formas que lhes restam, no sentido de se colocarem no mundo dos sujeitos sociais".

Esta questão está ligada à classe social em que a mulher está inserida, pois em alguns grupos sociais, atualmente, as mulheres têm mais oportunidade e opções de inserção na vida pública como estudo e trabalho e isto pode contribuir para que a adolescente tenha uma melhor auto-estima, mais acesso à informação e possibilidade de estabelecer outros projetos de vida, e lançar para o futuro os projetos da maternidade.

Dessa forma compreendemos que a questão da idade em que a mulher "pode" engravidar deve ser considerada mais como um fato social do que biológico ou psicológico. A gravidez e maternidade na adolescência nem sempre se constituem num problema para a mulher que engravida, mas podem, sim, fazer parte de um desejo real dela, sendo um projeto de vida da adolescente, devido à falta ou dificuldade de acesso à educação formal, educação sexual e trabalho remunerado, o que leva a mulher jovem a encontrar na gravidez na adolescência uma possibilidade de realização pessoal, de algo que pode ser alcançado, um papel social que ela pode desenvolver e ser reconhecida por ele.

Pitanguy (2003) "aponta a incidência da gravidez na adolescência como um problema a ser enfrentado" (p. xvii), porém acreditamos que não devemos considerá-la como um problema por si só, antes, devemos analisar a idade e em que condições ela ocorreu, e as conseqüências para a vida de homens e mulheres. A gravidez, se for desejada, acontecendo, no final da adolescência, não tem que ser vista como uma tragédia (GUIMARÃES, 2001).

A maternidade e a maternidade na adolescência podem ser entendidas como uma construção social e, portanto histórica, que podem estar ligadas à construção da identidade da mulher através deste evento. Dessa forma, para modificar essa ocorrência se faz necessário produzir um processo de desconstrução, para que se possa transformar a lógica 
dos sistemas tradicionais de pensamento, sendo necessária a oferta de novas oportunidades e informações para todos os grupos sociais e, assim, desencadear esse processo de modificar a realidade.

Atualmente a inserção social da jovem pode influenciar no julgamento quanto à ocorrência da gravidez e maternidade em idade precoce. A mesma pode ser vista com "espanto e revolta quando está o evento presente nas classes mais favorecidas e de conformação e até mesmo de fatalidade nas menos favorecidas" (SAITO, 2001, p. 6). Isso irá depender de o quanto a ocorrência poderá interferir nos projetos futuros destas jovens.

Um estudo, realizado com “jovens mães”, de classes populares, residentes em favelas do município de São Paulo, verificou que a experiência de engravidar na adolescência, para a maioria das entrevistadas, aconteceu em meio a turbulências dadas as adversidades emocionais porque passavam diante da confirmação da gravidez, vivenciando sentimentos de solidão e tentativas de aborto (SANTOS, 2001). A autora considerou que o parto para estas jovens simbolizou o rito de passagem para a vida adulta, com a maioria delas passando a se ver como mulher depois do parto. Ela constatou que a gravidez na adolescência não pode ser considerada tão indesejável como antes se imaginava, e os fatores para esta gravidez estavam relacionados a questões familiares; desejo, mesmo que inconscientemente, de rompimento com o espaço familiar.

Houve, também, a constatação da repetição, por estas jovens, da história de vida de suas mães no que diz respeito à gravidez na adolescência, sendo que o cotidiano delas encontrava-se marcado pelas desigualdades sociais, de gênero e pela violência existente no espaço onde residem, construindo e transformando suas identidades dentro deste contexto (SANTOS, 2001).

Em outro estudo sobre sexo e gravidez, encontraram-se problemas como alcoolismo, desestruturação familiar, baixo nível socioeconômico, carência de ordem afetiva, uma figura paterna bastante externalizada, e suas conclusões se baseiam em que estes fatos poderiam contribuir para o início precoce da atividade sexual e uma conseqüente gravidez (TAQUETE, 1992).

De acordo com Clapis (1996 p. 6), "as mulheres, através da construção social da identidade feminina, possuem uma tendência a ter uma baixa auto-estima, o que, normalmente, as coloca em situação de desvantagem [...]”. Compreendemos que nesta configuração algumas mulheres acabam por se submeter a uma maneira de viver, 
determinada pelo contexto social em que estão inseridas, sem perspectivas ou condições sociais de buscarem formas de se realizarem que não seja através do matrimônio e da maternidade.

Os estudos sobre o tema sugerem que a gravidez na adolescência é um fenômeno complexo e que talvez tenha uma particular relação com os valores culturais, especialmente com as representações de gênero nos contextos sociais em que vivem os jovens brasileiros.

A plataforma de ação de Beijing reconhece os obstáculos da mulher em todas as esferas da vida pública e privada e supõe o estabelecimento do princípio de que as mulheres e os homens devem compartilhar o poder e as responsabilidades da casa e do trabalho e para obter um desenvolvimento sustentado baseado no ser humano, é indispensável que haja uma relação transformadora baseada na igualdade entre mulheres e homens (ONU, 1995). Isso se relaciona também aos direitos reprodutivos de mulheres e homens em todas as idades.

Pitanguy (2003) afirma que ao se traçarem programas de saúde reprodutiva, deve-se levar em consideração que a gravidez na adolescência é também tida como um valor, principalmente pelas mulheres, de grupos sociais, que não têm acesso a outras formas de realização pessoal.

Para Heilborn (2002), é a inserção do indivíduo em diferentes esferas sociais que determina a maneira de perceber o mundo, o que significa dizer que as escolhas e preferências deles são socialmente fabricadas e definem os valores do grupo social. Dessa forma, pretendemos ampliar a compreensão da maternidade na adolescência além da responsabilidade individual e do enfoque epidemiológico do risco, contemplando as questões relacionadas com os fatores sociais, econômicos, políticos do grupo estudado, pois a maternidade na adolescência tem conseqüências distintas na vida de mulheres e homens. 


\section{OS DIREITOS REPRODUTIVOS}

\subsection{SAÚDE REPRODUTIVA E O MOVIMENTO DE MULHERES}

O feminismo como movimento coletivo de luta de mulheres se manifesta como tal na segunda metade do século XIX. Essas lutas se apoiaram no reconhecimento das mulheres como sistematicamente oprimidas, porém sabendo que a possibilidade política de transformação existe (FOUGEYROLLAS-SCHWEBEL, 2002).

De acordo com Elósegui (2002), existem diversas formas de entender o feminismo inclusive desde seu próprio nascimento. Neste sentido a autora afirma que se poderia falar de um elemento comum desde o início do movimento feminista que é a luta contra o patriarcado, a subordinação das mulheres e a reivindicação da igualdade.

Historiadoras e feministas distinguem duas ondas históricas do movimento feminista na América do Norte e na Europa: a primeira que surge no final do século XIX e se apresenta em torno das reivindicações do direito ao voto; a segunda aparece no século XX por volta da década de sessenta e começo da de setenta e se fundamenta sobre a bandeira da exigência da igualdade, como também o reconhecimento da impossibilidade de se fundamentar esta igualdade em um movimento patriarcal (FOUGEYROLLASSCHWEBEL, 2002).

Segundo Fougeyrollas-Schwebel (2002), falar de movimentos feministas permite designar debaixo de uma mesma denominação as diversas formas dos movimentos de mulheres, o feminismo liberal, o "burguês", o feminismo radical, as mulheres marxistas ou socialistas, entre outras modalidades atuais. Ainda que o feminismo contemple distintas tendências políticas, a premissa de partida da política feminista é a existência real ou potencial de uma identidade comum a todas as mulheres (MOORE, 1999). 
O movimento organizado de mulheres, no Brasil, ganha expressão no século passado nas décadas 70 e 80 , em meio à conturbação nacional de violência do Estado contra a população civil.

Durante o regime militar, o cenário político era dominado pelo debate em torno dos direitos civis e políticos, como supressão de liberdade individuais, inclusive do direito ao hábeas corpus, as dificuldades de organização político-partidária, o cerceamento do parlamento, dos sindicatos, da liberdade de imprensa, a violência do Estado, a tortura, questões fundamentais que marcavam os embates entre forças democráticas e o regime autoritário (PITANGUY, 2002, p.12).

Nesse contexto conturbado em que vive a América Latina, "a questão de gênero para a esfera pública, que alarga as discussões sobre poder, cidadania e desigualdade [...]" (PITANGUY, 1999, p. 21) faz com que o Estado mantenha, com o movimento de mulheres, a mesma atitude que caracterizava sua relação com a sociedade civil, ou seja, enxergava-o com desconfiança, considerando-o como uma potencial ameaça à ordem estabelecida.

O movimento feminista identificava uma invisibilidade da presença da mulher no cenário político e institucional brasileiro, dessa forma foram estabelecidas metas de luta em torno do direito ao uso do corpo, a opção pela maternidade, a luta contra todas as formas de violência e a conquista de igualdade de oportunidades no mercado de trabalho (VALÉRY, 1996).

O movimento feminista firma-se, também, intimamente ligado ao debate sobre o controle da população e ao planejamento familiar, fatos relacionados à questão de soberania nacional. Entretanto, com a abertura política, na década de 1980, foi possível através da integração entre governo, universidades e movimento feminista, buscar novos horizontes para as questões relacionadas à reprodução e o resultado foi a edição do Programa de Assistência Integral à Saúde da Mulher (PAISM), divulgado, em 1983.

Foi, a partir de meados dos anos 1980, que o campo da saúde da mulher ou saúde reprodutiva começou a receber atenção do movimento de mulheres. Nesse novo contexto, criou-se o do Conselho Nacional dos Direitos da Mulher (CNDN), ligado à Comissão Nacional de Estudos dos Direitos da Reprodução Humana no Ministério da Saúde, quando também se formulou o PAISM. O programa contemplava, em suas linhas de ação e estratégias, um modelo assistencial em cujo contexto se incluem a integralidade e a eqüidade, sendo a saúde da mulher abordada de maneira global e em todas as fases do ciclo 
vital (BRASIL, 1984).

O movimento feminista,

[...] reconhecendo o direito das mulheres de vivenciarem a maternidade como opção - com acesso à informação, à contracepção segura e ao tratamento da infertilidade, ao pré-natal e ao parto em condições adequadas, bem como à interrupção voluntária da gravidez, ao tratamento às seqüelas do abortamento provocado, à prevenção do câncer mamário e cérvico-uterino - luta para que o Estado desenvolva ações propositivas em saúde reprodutiva (PITANGUY, 1999, p. 27).

Esse programa constitui uma das primeiras iniciativas do Estado em políticas de saúde, incluindo princípios defendidos pelas feministas. (PITANGUY, 1999). O PAISM abrange um modelo conceitual integral com muitos avanços, incluindo a mulher no seu ciclo vital voltando sua atenção, não mais apenas para o ciclo gravídico-puerperal.

Constata-se uma evolução nos movimentos feministas que permitiu conquistas internacionais através do estabelecimento dos direitos das mulheres e direitos reprodutivos. Segundo Valéry (1996), “o espaço ocupado pelas mulheres foi conquistado a duras penas, mas de modo crescente e significativo" (p.31). Assim sendo, vamos apresentar alguns documentos da Organização das Nações Unidas (ONU) sobre a igualdade entre homens e mulheres e as Conferências Mundiais sobre População e Desenvolvimento.

Em 1967, a Assembléia Geral das Nações Unidas aprovou a Declaração sobre a Eliminação de todas as Formas de Discriminação contra a Mulher e, em 1979, aprovou a Convenção para Eliminação de todas as Formas de Discriminação contra a Mulher (CEDAW) cujo documento considera que os Estados têm a obrigação de garantir a homens e mulheres a igualdade em no exercício de todos os direitos econômicos, sociais, culturais, civis e políticos.

A CEDAW destaca e reconhece a importância social da maternidade e a função dos pais na família e na educação dos filhos, assim como o fato de que o papel da mulher na procriação não deve causar discriminação; em todo caso, a educação das crianças exige a responsabilidade compartilhada entre homens e mulheres e a sociedade em seu conjunto. $\mathrm{O}$ artigo 5 , inciso $b$, cita a responsabilidade comum de homens e mulheres quanto à educação e ao desenvolvimento dos filhos e no artigo 10, inciso $h$, coloca o acesso a material informativo específico que contribua para assegurar a saúde e bem-estar da família, incluídos a informação e o assessoramento sobre planejamento familiar (ONU, 1979). 
No ano de 1999, a Assembléia Geral adotou o Protocolo Facultativo para Eliminação de todas as Formas de Discriminação contra a Mulher que permite que as vítimas de discriminação por motivos de gênero apresentem denúncias ao Comitê para a Eliminação de todas as Formas de Discriminação contra a Mulher, em que o Brasil tem uma representante (ELÓSEGUI, 2002; ONU, 1979; ONU, 1999).

No México, em 1975, aconteceu a Conferência Internacional da Mulher, com o objetivo de promover a eliminação das desigualdades entre homens e mulheres e “incrementar a participação das mulheres nas atividades econômicas, políticas, sociais e culturais, em todos os níveis" (VALÉRY, 1996). A partir desta conferência, houve uma crescente preocupação, nos círculos desenvolvimentistas, acerca dos problemas que a mulher deve enfrentar, nos países em desenvolvimento em sua vida social econômica (BENERÍA; SEM, 1982).

A fim de analisar as ações desenvolvidas e propor novas direções para eliminar as desigualdades e desvantagens das mulheres existentes no processo de desenvolvimento foi realizada uma Conferência em Copenhague em 1980, depois em 1985 aconteceu a Conferência Mundial de Nairóbi que deixou patente que a situação de discriminação da mulher havia ganhado visibilidade (VALÉRY, 1996).

Na Conferência Internacional da População e Desenvolvimento, ocorrida no Cairo, em 1994, foi assegurado no seu relatório final que a mulher tem direito e poder sobre seu corpo, "tomando decisões sobre a sua vida sexual e reprodutiva, e [...] o Estado tem o dever de fornecer os meios para que esta autoridade seja, de fato exercida, ampliando sua ação no campo da saúde" (PITANGUY, 1999, p. 28).

No documento do Cairo se estabelece a definição sobre saúde reprodutiva, tendo sido a mesma reafirmada, em 1995, na IV Conferência Mundial sobre a Mulher, Desenvolvimento e Paz ocorrida em Beinjin, cujo texto relata o seguinte:

A saúde reprodutiva é um estado de completo bem-estar físico, mental e social, e não de apenas ausência de enfermidades ou doenças, em todos os aspectos relacionados com o sistema reprodutivo, suas funções e processos. Conseqüentemente, a saúde reprodutiva implica a capacidade de desfrutar de uma vida sexual satisfatória sem riscos e de procriar, bem como implica a liberdade para decidir entre fazê-lo ou não, quando e na freqüência desejada ${ }^{1}$ (FAMILY CARE INTERNATIONAL, 1995, p. 16; ONU, 1995, p. 37).

\footnotetext{
${ }^{1}$ Tradução da pesquisadora
} 
Esse novo direito chamado de saúde reprodutiva inclui: o acesso a serviços de planejamento familiar, conselho e informação, atenção pré-natal e ao parto, atenção médica para os recém-nascidos, tratamentos para as doenças do aparelho reprodutivo e das doenças transmissíveis sexualmente, serviços para o aborto seguro e tratamento apropriado para as infertilidades entre outros (ELÓSEGUI, 2002).

Essas conferências contribuíram para a inclusão das palavras "homens/masculino" em textos que estariam "tratando de temas associados tradicionalmente às problemáticas femininas [...], relacionados ao campo da saúde reprodutiva e direitos reprodutivos" (ARILHA, 1999, p. 456). A autora afirma que, apesar de geneticamente homens e mulheres contribuírem igualmente na reprodução, não existe "igualdade de participação no processo reprodutivo em termos de volume de trabalho corporal que a reprodução acarreta para cada um dos sexos" (ARILHA, 1999, p. 458).

Seguindo essa mesma linha de raciocínio a Conferência de Beinjin, quando se fala sobre a escolha da maternidade, traz implícito

[...] os direitos do homem e da mulher de obter informação sobre planejamento familiar de sua escolha, efetivos, assim como o direito de buscarem outros métodos para a regulação da fecundidade que não estejam legalmente proibidos, e acesso a métodos seguros, eficazes, acessível e aceitável, ou o direito de receber serviços adequados de atenção à saúde que permitam a gravidez e partos sem riscos e ofereçam aos casais as possibilidades de ter filhos sadios ${ }^{1}$ (ONU, 1995, p. 37).

Nessa perspectiva a atenção à saúde reprodutiva foi definida como

[...] o conjunto de métodos, técnicas e serviços que contribuam para a saúde e o bem-estar reprodutivo ao prevenir os problemas relacionados com a saúde reprodutiva. Inclui também a saúde sexual, cujo objetivo é o desenvolvimento da vida e das relações pessoais e não somente o aconselhamento e a atenção referentes à reprodução e às doenças sexualmente transmissíveis ${ }^{1}$ (ONU, 1995, p. 37).

Nessa Conferência também foi defendido o conceito de direito sexual trazendo, na primeira parte, uma visão de que a mulher é responsável por sua sexualidade, sendo definido da seguinte forma:

Os direitos humanos da mulher incluem o direito de ter o controle sobre as questões relativas a sua sexualidade, incluindo sua saúde sexual e reprodutiva, e decidir livremente e responsavelmente a respeito dessas questões sem vir a ser submetida à coerção, discriminação e a violência ${ }^{1}$ (ONU, 1995, p. 38).

Na seqüência, o direito sexual é tratado como uma responsabilidade compartilhada entre homens e mulheres, o que na prática é um grande desafio visto que: 
As relações igualitárias entre homens e mulheres a respeito das relações sexuais e a reprodução, que incluem o pleno respeito da integralidade da pessoa, exige o respeito e o consentimento recíproco e a vontade de assumir conjuntamente a responsabilidade das conseqüências do comportamento sexual ${ }^{1}$ (ONU, 1995, p. 38).

O movimento feminista tem apresentado importantes contribuições no debate sobre família, sexualidade e reprodução, junto aos parlamentares e influenciando nos avanços do legislativo, em defesa dos direitos sociais de homens e mulheres, e também os direitos à saúde, incluindo a saúde reprodutiva (BARSTED, 1999).

A Conferência de Beijin em sua declaração reconhece as aspirações das mulheres do mundo inteiro e faz registro das diversidades delas e de suas funções e circunstâncias, fazendo honra a elas que abriram o caminho. Sabe-se que a situação da mulher avançou em alguns aspectos importantes no último decênio, ainda que os progressos não tenham sido homogêneos, pois persistem as desigualdades entre homens e mulheres e seguem sendo obstáculos importantes que trazem graves conseqüências para o bem-estar de todos os povos.

Apesar do avanço das propostas ocorridas como resultados das conferências, também tem sido reconhecido que a situação é agravada pela pobreza cada vez maior, que afeta a vida da maior parte da população do mundo e tem suas origens em âmbito nacional e internacional (ONU, 1995). Esta situação de pobreza repercute na vida das mulheres participantes deste estudo.

\subsection{MATERNIDADE E GÊNERO}

Acreditamos ser importante verificar que as expectativas sociais diante da idade, que a pessoa apresenta em determinado momento de sua vida, se modificam social e historicamente e o que em um momento parece aceitável e "natural" em outra situação não o é. O fato é que estudos socioantropológicos utilizam o conceito de geração substituindo idade e "para cumprir o projeto de relativização do tema distancia-se dos fatores laivos biomédicos que a palavra idade pode reter" (HEILBORN, 1998, p. 23). Assim um problema pode ter seu ângulo alterado, conforme as preocupações de uma agenda social. 
Com isso pode-se demonstrar que compreender a maternidade implica em lições a serem apreendidas ao olhar o outro, e deve-se ressaltar que em relação à maternidade "[...] existem muitas maneiras de ser mãe. A maternidade é modelada pela cultura, pode ser adaptativa e pode ser flexível" (FORNA, 1999, p. 32).

Atualmente, a concepção de direitos reprodutivos, saúde sexual e outros conteúdos relacionados aos direitos sexuais que, antes estavam protegidos sob a égide de saúde reprodutiva, vêm sendo largamente discutidos pelos movimentos de mulheres em diversos continentes (CORRÊA, 1999). No que diz respeito aos direitos humanos das mulheres, descreve-se que neles estão incluídos os direitos de controlar sua sexualidade, saúde sexual e reprodutiva, e implica em poder tomar decisões "livremente a respeito dessas questões, sem verem-se sujeitas à coerção, à discriminação ou a violência" (CORRÊA, 1999, p. 42), ou seja, ter e exercer a liberdade sobre o seu corpo.

Uma análise sobre a maternidade considera que ela se transformou no que é hoje: "um dos estados humanos mais naturais, e um dos mais policiados; uma responsabilidade única da mulher; não apenas um dever, mas uma vocação altamente idealizada, cercada de emoção por todos os lados" (FORNA, 1999, p. 55). Segundo a autora, a situação já era ruim o bastante "para as mães vitorianas, mas ficaram piores no decorrer do século XX, quando a ciência, a psicologia, a política e a polêmica em torno dos gêneros levaram o mito da maternidade além dos limites" (FORNA, 1999, p. 55).

A união dos conceitos de gênero e sexualidade dificulta a operacionalização teórica e política quando relacionados aos direitos sexuais. Não é tarefa fácil diferenciar as relações de gênero, sexualidade e erotismo, pois em todas as organizações socioculturais “[...] atuam sistemas de representação muito coesos que ordenam gênero, reprodução e sexualidade em articulação com a economia e o poder" (CORRÊA, 1999, p. 45). A distinção entre estes conceitos é importante para sedimentar os princípios dos direitos reprodutivos, resgatando a possibilidade de libertação da sexualidade, assim como, "é um passo crítico para identificar, aceitar e tornar visível o agenciamento sexual, o erotismo e o prazer das mulheres, que foram, de algum modo, submergidos na lógica do poder e na dominação dos sistemas de gênero" (CORRÊA, 1999, p. 47).

Em uma pesquisa realizada com homens em uma empresa metalúrgica na cidade de São Paulo, com o objetivo de identificar necessidades deles sobre educação para a sexualidade e orientação para a saúde reprodutiva observou-se que a preocupação com a 
reprodução “[...] constrói-se no contexto social, e não na relação com o seu próprio corpo. A vida reprodutiva de um homem não diz respeito, portanto, à relação direta com sua saúde reprodutiva" (ARILHA, 1999, p. 460). Os homens entrevistados nesta pesquisa apontavam que, no campo das decisões sobre a vida reprodutiva, são as mulheres quem coordenam este processo, e que muitas vezes se vêem obrigados a modificar o rumo de suas vidas porque aceitaram delegar tal responsabilidade nesse processo.

Estes homens afirmaram que quando são vítimas deste processo de liderança feminina nas questões reprodutivas, fato que, às vezes, "lhes acarreta paternidade prematura, vão se tornando, a posteriori mais eficientes no controle da fertilidade" (ARILHA, 1999, p. 463). A autora crê que parecem existir diferenças entre homens e mulheres sobre os processos reprodutivos. "Mulheres desejam ter filhos; homens desejam a família" (ARILHA, 1999, p. 464). Como resultado deste estudo, a autora conclui que a reprodução está ligada com as questões de saúde, e que os homens se encontram mais distantes das orientações sobre estas questões e sobre a saúde reprodutiva. Dessa forma eles deveriam ser estimulados a participarem de discussões sobre planejamento familiar.

Quanto à visão da sociedade sobre a maternidade, observa-se ainda a existência de pensamentos distintos a depender da classe social ou condição social da mulher, e ao se comparar como a mídia circunscreve a posição da mãe solteira e da mãe casada apontando que as mesmas têm sido colocadas como adversárias, "mas juntas ilustram perfeitamente os laços entre a economia, a moralidade e a maternidade. Uma mulher rica que abandona o emprego para ficar em casa é vista como virtuosa, e a pobre, como criminosa" (FORNA, 1999, p. 133). Afirma ainda que vemos beleza na maternidade para todas as mães, "mas desprezamos e arrasamos as mulheres pobres que a desejam. Falamos do vínculo, do amor e da convivência entre mãe e filho, enquanto reduzimos o pai ao papel de provedor" (FORNA, 1999, p. 142).

As concepções acerca da maternidade estão se transformando lentamente e gestar e criar filhos são dimensões humanas, ainda importantes, especialmente para as mulheres "para quem a maternidade representa um importante suporte narcísico e ao mesmo tempo representa a constituição de seu lugar social” (ARILHA, 1999, p. 11).

Entre mulheres adolescentes de uma comunidade pobre, a maternidade pode ser a principal forma de ser reconhecida socialmente, pois neste grupo as oportunidades são menores devido às dificuldades sociais de se manterem na escola ou de encontrarem um 
trabalho que lhes dêem satisfação individual e recursos financeiros suficientes para sua manutenção. Dessa forma a maternidade na adolescência pode ser vista como uma ação coletiva e não apenas como uma ação individual.

Apesar das transformações que estão ocorrendo na sociedade, cabem às mulheres, sobretudo, as atividades reprodutivas e os cuidados com a casa e a família, ficando o homem com o papel de provedor, e isso influencia a participação de cada um no mercado de trabalho (BRUSCHINI, 1999).

Não obstante a maternidade ainda ser analisada como uma função importante na vida da mulher e, portanto, as mulheres não a abandonaram em seus projetos de vida, a organização social atual tem experimentado novas configurações de família. Nelas há decréscimo na fecundidade, e no Brasil, este fato já tem interferido nos padrões reprodutivos do país (ARILHA, 1999; CAMARANO; ARAUJO; CARNEIRO, 1999; CAMARANO, 1998a).

Porém observamos que isto não se dá de forma homogênea em todo o país. Em Alagoas, verifica-se um pequeno decréscimo na taxa bruta de fecundidade por 100 mulheres que, no período de 1994 a 2001, passou de 3,88 para 3,10. Mas o mesmo não ocorreu em Maceió tendo aumentado de 3,20 em 1994 para 3,60 em 2001 (BRASIL, 2004).

Para que as mulheres e os homens possam exercer seus direitos reprodutivos, se faz necessário que lhes sejam assegurados educação formal, conhecimentos adequados sobre a sexualidade humana, acesso a serviços de saúde de qualidade, informação sobre o planejamento familiar, acesso a métodos contraceptivos que se adequem a suas necessidades.

Antigamente não se prevenia a concepção porque existia uma necessidade de mãode-obra, ou seja, braços para trabalhar nos teares, além de uma obediência cega ao princípio bíblico “crescer e multiplicar”. Forna (1999, p. 57) afirma que "no passado, muita gente sabia, ou achava que sabia porque tinha filhos". Considera-se que "no contexto dos tempos modernos, é tão possível que os filhos sejam produtos de nossas emoções desejo, paixão, altruísmo, egoísmo, amor, tédio e vaidade - quanto de uma compulsão profundamente enraizada, biologicamente traçada" (FORNA, 1999, p. 57). 
No Brasil, verifica-se que, no período de 1935-95, houve um aumento da fecundidade no grupo etário de 15 a 19 anos e uma redução expressiva no grupo de 20 a 24 anos que, tradicionalmente, apresentava taxas de uma fecundidade mais alta. Esta queda também não aconteceu de forma linear, sendo que o período em que ocorreu maior crescimento da fecundidade no grupo de 15 a 19 anos coincide com o de maior redução entre as mulheres de 20 a 24 anos (CAMARANO, 1998b).

O PAISM, com seus acertos e desacertos, foi formulado dentro desse contexto de redução da fecundidade, "de forma a contemplar as necessidades de saúde das mulheres incluindo aquelas no campo da concepção e da contracepção" (ARILHA, 1995, p. 4). Apesar do avanço no uso dos contraceptivos no Brasil, "as mulheres continuam construindo suas histórias de vida no campo das decisões reprodutivas" (ARILHA, 1995, p. 5). Entretanto a garantia de acesso à informação a todos os métodos contraceptivos, preconizados pelo PAISM, não tem sido contemplada e sua oferta nos serviços públicos de saúde é ainda muito deficiente (GIFFÍN; COSTA, 1999), ficando as mulheres sem opção para escolher o método que melhor se adeqüe às suas necessidades, principalmente as mulheres das camadas mais pobres da população.

O informe da ONU (1995) sobre a quarta Conferência Mundial sobre a Mulher trata da necessidade dos adolescentes terem acesso ao ensino e aos serviços com o objetivo de poderem assumir sua sexualidade de maneira positiva e responsável e isso significa atendimento à saúde reprodutiva. $\mathrm{O}$ informe, também, escreve sobre a necessidade de melhorar o acesso a serviços adequados de atenção à saúde incluídos os métodos de planejamento familiar eficazes e sem riscos, assim como a atenção obstétrica de emergência, pois reconhece o direito de mulheres e homens à informação e ao acesso a métodos contraceptivos seguros.

A Lei no 9.263, de 12 de janeiro de 1996 que regula o parágrafo 7 do artigo 226 da Constituição Federal, e que trata do planejamento familiar estabelece no seu art. $3^{\circ}$ que o mesmo é parte integrante do conjunto de ações de atenção à mulher, ao homem ou ao casal, dentro de uma visão de atendimento integral à saúde e que todas as instâncias gestoras do SUS obrigam-se a garantir, em toda a sua rede de serviços, programas de atenção integral à saúde, em todos os seus ciclos vitais, que incluam, como atividades básicas, entre outras, a assistência à concepção e contracepção e o atendimento pré-natal, entre outros. 
Essa lei, também, estabelece no seu artigo $4^{\circ}$ que o planejamento familiar orienta-se por ações preventivas e educativas e pela garantia de acesso igualitário à informação, meios, métodos e técnicas disponíveis para a regulação da fecundidade. Porém observamos que até 2002, a lei não se encontrava aplicada em todas as unidades de saúde da família de Maceió, pois não se pode fazer planejamento familiar quando não se dispõe de métodos para contracepção que se adequem às necessidades das mulheres, dos homens ou do casal.

No que diz respeito ao planejamento familiar, as recomendações para o setor da saúde incluem a melhoria no acesso da população pobre ao planejamento familiar, focalizando os homens como parceiros nos programas de saúde reprodutiva e de sexualidade (PITANGUY, 2003).

Dessa forma, quando os conhecimentos sobre sexualidade e saúde reprodutiva são inadequados, não existe uma atenção adequada ao planejamento familiar nos serviços de atenção à saúde, e homens e mulheres pobres ficam sem condições de exercerem os seus direitos de decidir sobre a questão da maternidade. Assim sendo, mulheres que não são atendidas adequadamente em suas necessidades de saúde sexual e reprodutiva sentem-se motivadas para o uso de contracepção definitiva.

Segundo Pitanguy (2003), deveria ser desencorajada a esterilização como método de planejamento familiar que pode levar a uma redução no uso de camisinhas e não ser uma opção para as mulheres jovens que podem planejar ter filhos mais tardiamente na vida, como também representa uma alta despesa para o sistema de atenção à saúde. A autora afirma que no Nordeste os programas de saúde reprodutiva deveriam visar à redução da gravidez juvenil. Porém acreditamos que a redução da gravidez na adolescência no Nordeste não pode ser efetivada apenas por programas de saúde reprodutiva, pois está relacionada com as questões de gênero e ligadas à condição social dos jovens.

A esterilização cirúrgica parece estar presente na vida das mulheres inseridas no mercado de trabalho com uma perspectiva de realização pessoal, e esta motivação sempre esteve ligada à necessidade de não ter mais filhos "respaldada pela vontade de criar bem os filhos, ter acesso ao mundo do trabalho como forma de atingir meios para poder oferecer bens concretos aos filhos" (ARILHA, 1999a, p. 8).

Considera-se que usar contraceptivos não significa que a mulher terá uma ampliação das oportunidades no mundo público, portanto, apenas o acesso ao 
contraceptivo não dá garantia às mulheres de uma percepção melhor de si mesmas, apesar de dar possibilidades de buscar novas alternativas para suas vidas (ARILHA, 1999).

Para ampliar as oportunidades das mulheres no mundo público, é necessário o combate à pobreza oferecendo oportunidades de crescimento e desenvolvimento econômico; de educação formal e capacitação para o mercado de trabalho; melhorando o acesso aos serviços de saúde, assim como capacitá-los a atender às necessidades de saúde e informação das mulheres de forma a lhes dar maior autonomia sobre suas vidas. 


\section{REFERENCIAL TEÓRICO-METODOLÓGICO}

\subsection{CONCEPÇÕES SOBRE GÊNERO}

O termo gênero provém do campo da literatura e foi introduzido na teorização feminista no século XX a partir dos anos setenta, aplicado à psicologia e à antropologia e tem tido uma especial relevância nos países anglo-saxões (ELÓSEGUI, 2002; TUBERT, 2003). Em um contexto tanto filosófico como político, ao final do século XX, reconhece-se o fato de que as características físicas dos sexos, cuja realidade é em si mesma problemática, não são mais o suporte de uma identificação, não só individual como também coletiva, para os homens e as mulheres e que, em conseqüência, a crítica das concessões sexuais exige uma nova terminologia para estas discussões (FRAISSE, 2003).

O pensamento feminista conceitualiza a crítica da dualidade sexual entre feminino e masculino, sendo gênero o termo portador desta crítica, sendo necessário entendê-lo como uma proposição filosófica que simboliza a necessidade de pensar a diferença entre os sexos (FRAISSE, 2003). Sendo também “[...] uma maneira de se referir à organização social da relação entre os sexos" (SCOTT, 1995, p. 72), fazendo uma oposição ao sexo, ocultando a diferença entre os sexos através de uma neutralidade da língua e expondo o caráter de construção sociocultural dessa diferença (TUBERT, 2003).

Para Scott (1995), algumas teorias formuladas entre o século XVIII e início do XX construíram seu raciocínio em conformidade com a oposição entre masculino e feminino. Algumas reconheceram a existência de uma questão feminina e outras se preocuparam com 
a identidade sexual subjetiva, porém gênero como expressão dos sistemas de relações sociais ou sexuais não era contemplado.

Ainda que os objetivos de cada corrente do feminismo fossem diferentes, com o tempo os debates tiveram um argumento comum frente a inimigo comum, ou seja, a subordinação da mulher ao homem. Dessa forma foi possível alianças importantes do ponto de vista teórico. As feministas liberais põem ênfase no acesso da mulher ao trabalho e ao direito ao voto, enquanto as socialistas se sentem comprometidas com uma estrutura de classe e desenvolvimento dos mais desfavorecidos socialmente e o acesso dos mesmos à educação, incluídas as mulheres. As anarquistas e marxistas pretenderam uma mudança total das estruturas para fazer desaparecer instituições como matrimônio e a família, colocando entre seus objetivos prioritários a abolição da família e da paternidade (ELÓSEGUI, 2002).

Segundo Scott (1995, p. 85), a incorporação do termo gênero como uma categoria analítica "faz parte da tentativa aprendida pelas feministas contemporâneas para reivindicar um certo terreno de definição, para sublinhar a incapacidade teórica existente para explicar as persistentes desigualdades entre as mulheres e os homens".

Os estudos de gênero podem ser utilizados para designar as relações sociais entre os sexos, como também é uma maneira de indicar as construções sociais dos papéis próprios aos homens e às mulheres. Scott $(1995$, p. 86) propõe uma definição complexa e multidimensional que repousa sobre a conexão de duas proposições: "o gênero é um elemento constitutivo de relações sociais baseadas nas diferenças percebidas entre os sexos" e também "é uma forma primária de dar significado às relações de poder".

Em seu primeiro aspecto, esta definição compreende os símbolos culturalmente disponíveis que evocam as representações múltiplas como, por exemplo, Eva e Maria como símbolos da mulher; os conceitos normativos que manifestam as interpretações dos significados dos símbolos com o intento de limitar e conter suas possibilidades representativas, como as doutrinas religiosas, educativas e científicas, políticas e jurídicas; as instituições e organizações sociais como o sistema de parentesco, como também o mercado de trabalho, a educação e a política. 
Na segunda parte da definição, a autora desenvolve sua teorização de gênero que corresponde às relações significantes de poder, ainda que o gênero não seja o único campo no qual ou por meio do qual se articula o poder. Segundo Louro (1997), é no interior das redes de poder e pelas trocas e jogos que constituem o seu exercício, que são instituídas e nomeadas as diferenças e desigualdades.

Na análise de Turbert (2003), a definição de gênero de Scott é completa e ampla, porém esta complexidade pode tornar difícil que se mencione ao mesmo tempo todas as dimensões colocadas, sendo mais provável que se aponte(m) algum (s) deles em especial.

Existe uma ligação entre gênero e poder, sendo o gênero a primeira forma de interpretar as relações de poder, que apesar de não explícito é uma dimensão decisiva para compreender a organização da igualdade e desigualdade entre os sexos. "As estruturas hierárquicas dependem de compreensões generalizadas das assim chamadas relações naturais entre o masculino e o feminino" (SCOTT, 1995, p. 88). A contribuição de Scott é fundamental para o debate quando propõe utilizar gênero como categoria de análise para que tenhamos a possibilidade de compreender as relações entre gêneros e a organização da sociedade.

De acordo com o conceito, gênero seria distinto de sexo. Dessa forma, usa-se o termo gênero com a intenção de separar o que é construção social do que seja um fato biológico, ou seja, fazer referência a toda a construção social relacionada com a distinção entre masculino e feminino, assim como as que separam o corpo masculino do corpo feminino (NICHOLSON, 2003).

Para Louro (1997), ao se dirigir o foco para o caráter fundamentalmente social de gênero não se pretende negar que ele se constitui com e sobre os corpos sexuados, ou seja, não é negada a biologia, porém se enfatiza, deliberadamente, a construção social e histórica produzida sobre as características biológicas, referindo-se a como estas características são compreendidas e representadas. Segundo a autora, dessa forma se pretende "recolocar o debate no campo social, pois é nele que se constroem e se reproduzem as relações (desiguais) entre os sujeitos" (LOURO, 1997, p. 22). 
Kergoat (1996, p. 19) também afirma que os "papéis sociais de homens e mulheres não são produto de um destino biológico, mas que são antes de tudo, construções sociais que têm uma base material".

Seguindo esta linha de raciocínio, Louro (1997, p. 41) observa que homens e mulheres seguramente não são "construídos apenas através de mecanismos de repressão ou censura, ambos se fazem, também, através de práticas e relações que instituem gestos, modos de ser e de estar no mundo, formas de falar e agir, condutas e posturas apropriadas $[\ldots] "$.

Segundo Heiborn (2002, p. 76), atualmente gênero se tornou uma categoria analítica cujo uso encontra-se bastante estendido, ainda que se deva assinalar que existem "diferentes apropriações teóricas em cima deste termo". Nas ciências sociais, os estudos de gênero foram e continuam sendo responsáveis por estudos sobre corpo e sexualidade.

As pesquisas sobre gênero não devem estar focalizadas apenas nas mulheres, elas devem focar sim os processos de formação dos sujeitos feminino e masculino, acenando para a idéia de relação, pois "os sujeitos se produzem em relação e na relação" (LOURO, 1997, p. 10), ou seja, "os gêneros se produzem, portanto, nas e pelas relações” (LOURO, 1997, p. 41).

O objetivo da aplicação desta categoria é compreender sua importância dentro de um contexto histórico e investigar a dimensão dos papéis sexuais em sociedades diferentes assim como em diferentes períodos, pois existe uma diversidade entre as culturas e em diferentes momentos da história.

As pesquisas sobre mulheres também apontam para estudos críticos de cada uma das proposições e das concepções dos trabalhos científicos, envolvidos nesta metodologia, não apenas uma nova história das mulheres, mas em dimensão na qual pudesse o gênero se desenvolver como uma categoria de análise (WITT, 1996).

$O$ conceito de gênero encontra-se também associado às relações de raça/etnia, classes, gerações, levando a constantes negociações e rearranjos dessas relações, pois gênero se constrói com elas e também através delas (MEYER, 1996; COSTA, 2002). Com base nas relações acima citadas, é possível evocar a dimensão política das relações entre o 
masculino e o feminino, sendo expresso, tanto nas trocas interdisciplinares como nas experiências individuais de quem produz o conhecimento, bem como as ligações entre o público e privado (COSTA, 2002).

Gênero, então, é entendido como uma construção social e, desta forma, histórica. O conceito de gênero é plural, com conceitos de feminino e de masculino, determinado social e historicamente de maneira diversa, o que implicaria admitir não apenas que sociedades diferentes teriam diferentes concepções de homem e de mulher, que podem se transformar ao longo de tempo, como também seriam diversificadas, conforme o gênero, a classe, a religião, a raça/etnia, a idade/geração que eles ocupam.

Homens e mulheres são construídos historicamente através de suas experiências de vida, não estando desligados do tempo e do espaço que ocupam, mas sendo conseqüência daquilo que vivenciam, onde cada um vê e conhece o mundo de acordo com suas perspectivas. As mulheres e os homens continuam a ocupar lugares tradicionalmente traçados, segundo o que se chama de sua "natureza" feminina ou masculina, sendo que, é esta mesma "natureza" que o feminismo contemporâneo tem procurado desconstruir (SWAIN, 2001).

Quando Louro (1996), também, afirma que gênero é uma construção social e, portanto, histórica, fala da necessidade dessa desconstrução, para se pensar sobre as questões de gênero. Para a autora, compreender gênero envolve supor as disposições do social e do biológico, embora continue se afirmando que sua construção é um processo social e histórico, mas admite que, nesse processo, os corpos dos sujeitos estão envolvidos, sendo constituídos e instituídos pelas múltiplas instâncias e relações sociais.

Desconstruir a polaridade rígida dos gêneros significaria problematizar tanto a oposição entre eles quanto a unidade interna de cada um, implicaria em: observar que o pólo masculino contém o feminino e vice-versa; perceber que cada um desses pólos é inteiramente fragmentado e dividido (LOURO, 1997).

$\mathrm{Na}$ busca de explicar o caráter social de gênero e a construção sociocultural das diferenças e desigualdades entre mulheres e homens, as teóricas feministas têm enveredado por diversos caminhos, ainda que considerem a opressão das mulheres o assunto principal 
que explica o desenvolvimento das sociedades humanas (FERREIRA; NASCIMENTO; PAIVA, 2003, p. 01).

É evidente que uma das abordagens centrais do feminismo tem sido a de propor a construção de identidades femininas sob outras bases e parâmetros conceituais, pois centralizar atenção unicamente nas necessidades, interesses, desejos e concepções masculinas não garante visão real e total das práticas sociais.

Entre os diferentes temas de interesse abordados pelo movimento e organização atual feministas inserem-se os direitos reprodutivos, com ênfase na maternidade segura, humanização do nascimento e parto, a descriminalização do aborto, violência doméstica e saúde integral da mulher (RAGO, 2001), mas há quem acredite que "o feminismo pouco fez para tocar diretamente o tema da maternidade. [...] pouquíssimo foi dedicado à maternidade, vista como parte integrante do pacote de opressão" (FORNA, 1999, p. 87).

Os limites teóricos que são apontados em diversos estudos apresentam basicamente duas linhas interpretativas: uma procura elucidar quais são os processos de dominação responsáveis pela ausência de participação feminina, e outra se baseia na dicotomia entre o público e o privado para diferenciar os papéis femininos e masculinos, enfatizando o posicionamento subordinado da mulher no âmbito privado devido aos seus papéis de mãe e esposa (BRITO, 2001).

O processo de desenvolvimento requer uma ampla compreensão da reprodução e das conseqüências que esta tem para a participação da mulher em todos os aspectos da vida econômica, sua análise inclui a sexualidade, a liberdade reprodutiva, a maternidade e o trabalho doméstico (BENÉRIA; SEM, 1982). Segundo estas autoras, a ênfase sobre a reprodução se dá através da análise das relações de dominação e subordinação entre os sexos dentro de uma unidade doméstica como um ponto central.

Dessa forma, entendemos que para compreender essas ocorrências, é preciso conhecer como essa construção ocorre, pois alguns grupos de mulheres têm tido novas oportunidades de inserção social, sendo, talvez necessário desencadear um processo de "desconstrução", para que possamos buscar entender como se constrói a identidade materna neste grupo social, e o seu papel social. Buscamos refletir sobre as questões de gênero relacionadas à ocorrência da maternidade na adolescência em uma comunidade 
economicamente desfavorecida, onde as jovens têm poucas ou nenhuma oportunidade de inserção social que não seja a maternidade e a vida doméstica.

O papel social da mulher é percebido próximo à natureza porque sua relação com a reprodução tendeu a limitá-las a determinadas funções, que também se percebem próximas à natureza, principalmente no que diz respeito ao confinamento da mulher ao mundo doméstico (MOORE, 1999). O trabalho doméstico é em sua maioria um trabalho universal da mulher em todos os países e regiões. Isto apesar do fato de se poder distinguir claramente entre a reprodução biológica, a manutenção diária da família e entre ter os filhos e cuidar deles (BENÉRIA; SEM, 1982).

Para Ortner (1979), a subordinação feminina é universal, mas esta condição não é inerente às diferenças biológicas entre os sexos, sendo necessário buscar outras explicações, pois as diferenças biológicas entre homens e mulheres somente têm sentido dentro de um sistema de valores culturalmente definidos, o problema da assimetria sexual encontra-se no mesmo nível das ideologias e dos símbolos culturais.

A autora sugere que a identificação ou associação simbólica das mulheres com a natureza e dos homens com a cultura começa com o corpo e a função de procriação natural, atividade específica das mulheres. Estas associações não procedem da natureza biológica ou social de cada sexo, mas sim da construção social.

A associação "natural" da mulher com as crianças e com a família proporciona uma nova classificação, dado que as mulheres estão relegadas ao contexto doméstico com sua principal esfera de atividades, girando em torno das relações intra e interfamiliares, frente à participação dos homens nos aspectos político e público da vida social. Dessa forma o homem se identifica com a sociedade e os interesses públicos, enquanto as mulheres continuam associadas à família (MOORE, 1999).

Moore (1999) verifica a necessidade de estudar os vínculos entre a idéia de mulher e de mãe, especialmente por parte dos pesquisadores que pretendem conectar a subordinação universal com o papel aparentemente universal da mulher como mãe e educadora. Para a autora, as categorias mulher e mãe se supõem em pontos fundamentais e bem diferenciados. As idéias acerca da mulher e a atitude a respeito dela estão fortemente unidas aos conceitos de casamento, família, lar, crianças e trabalho. O conceito de mulher 
se alinha através destas distintas idéias, e a mulher se conforma individualmente através das definições culturais de feminilidade, ainda que este processo se alimente de conflitos e contradições. O resultado final é uma definição de mulher que depende essencialmente do conceito de mãe e das atividades e associações concomitantes.

Rosalvo (1979) desenvolve uma análise dualista na explicação da subordinação das mulheres, fazendo uma reflexão sobre o trabalho de diversas autoras, verifica que, em todas as sociedades, a vida das mulheres tende a ser mais privada e doméstica, ao contrário da dos homens que tende a ser mais pública e social. A autora afirma que apesar da grande variabilidade dos papéis desempenhados por homens e mulheres em todas as sociedades conhecidas existe, contudo, uma desigualdade entre as atividades masculinas e femininas, pois se atribui mais valor às desempenhadas pelos homens do que àquelas destinadas às mulheres.

Para a autora, a oposição entre o doméstico e o público proporciona as bases de um modelo estrutural que permite identificar e explorar a situação masculina e feminina em seus diversos aspectos: psicológico, cultural, social e econômico. A mesma não "determina estereótipos culturais ou desigualdades nas valorizações dos sexos, mas antes, subordina-as a sustentar uma identificação [...] das mulheres com a vida doméstica e dos homens com a pública" (ROSALVO, 1979, p. 40).

Para Maquieira D'Angelo (2001), o trabalho de Rosalvo teve grande influência nas teorias feministas dentro e fora da antropologia e iniciou o debate sobre a dicotomia entre o doméstico e público. De acordo com a autora, a antropologia feminina teve uma importante contribuição ao questionamento das categorias binárias tais como natureza/cultura, doméstico/público; casa/trabalho; ou sentimento/razão inscritas como ponto central no pensamento ocidental como modelos de representação das relações de gênero e que se apresenta como oposições fixas que simplificam e mudam o sentido da vida de homens e mulheres.

Esses modelos de representação de gênero se traduzem em categorias conceituais para a análise social, tiveram e têm uma importante incidência na justificativa da desigualdade, já que cada um dos pólos dualistas se articula ideologicamente de um modo hierárquico e por meio deles a cultura tem preponderância sobre a natureza, o público com 
respeito ao doméstico e a produção sobre a reprodução (MAQUIEIRA D’ANGELO, 2001).

De acordo com Ortner (1979), os esforços dirigidos apenas na mudança das instituições sociais não podem ter efeitos de longo alcance se a linguagem dos elementos culturais continuam a fornecer uma imagem relativamente desvalorizada da mulher, assim como as mudanças de pretensões culturais não podem ser bem-sucedidas a menos que a base institucional da sociedade mude para a manutenção e o reforço de uma visão cultural modificada.

Para a autora, tanto homens como mulheres "podem e devem ser envolvidos igualmente em projetos de criatividade e transcendência, somente então, as mulheres serão associadas com a cultura no dialético progresso da cultura com a natureza" (ORTNER, p. 118).

Consideramos que a identidade de gênero é uma construção social, sendo influenciada pelo meio em que os indivíduos estão inseridos, e dessa forma a gravidez e maternidade na adolescência são, também, uma construção coletiva.

Adotando gênero como teoria de análise, compreendemos ser possível assinalar a elaboração sociocultural da maternidade na adolescência entre as mulheres que a vivenciaram e o papel de seus parceiros, pois esta teoria pode ser emancipatória, quando parte do fato de que as mulheres, por ser mulher, foram discriminadas nos diversos espaços da vida e suas oportunidades foram menores que as dos homens na mesma classe social, sendo necessário eliminar os obstáculos existentes.

Sentimos que esta tese nos dará uma nova luz para a compreensão da maternidade na adolescência no grupo de mulheres estudadas, também possui implicações para uma reflexão sobre essas mulheres e como o gênero poderá efetuar as mudanças necessárias para que elas realizem seus projetos dentro de um mundo mais igualitário. Para responder ao objetivo deste estudo estabelecemos como pressuposto que:

Mulheres, residentes na periferia de uma cidade do Nordeste, oriundas de uma camada social mais desfavorecida economicamente, podem estabelecer na maternidade na 


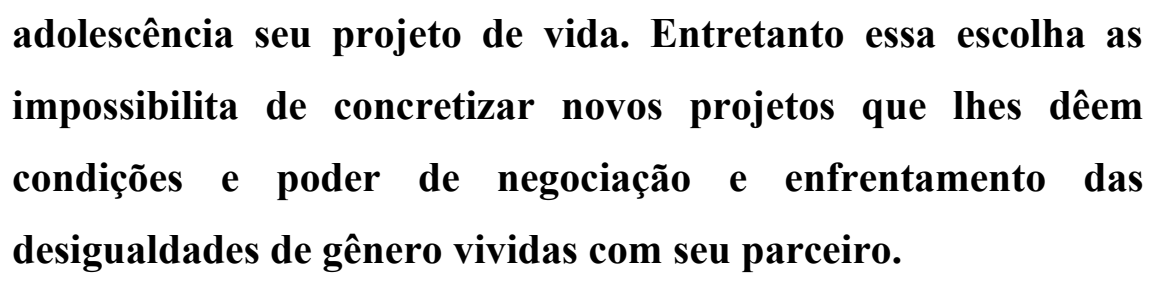

\subsection{PERCURSO DO MÉTODO}

Iniciamos transcrevendo o que Foucault (2002) escreveu sobre a verdade revelada existente em um discurso em que ele diz que nem tudo...

[...] é verdadeiro; mas em todo lugar e a todo o momento existe uma verdade a ser dita e a ser vista, uma verdade talvez adormecida, mas que, no entanto está somente à espera de nosso olhar para aparecer, à espera de nossa mão para ser desvelada. A nós cabe achar a boa perspectiva, o ângulo correto, os instrumentos necessários, pois de qualquer maneira ela está presente aqui e em todo lugar [...] (FOUCAULT, 2002, p. 113).

É na procura de desvelar esta verdade que estudamos as histórias de mulheres que foram mães na adolescência, buscando fornecer espaço para que este grupo, muitas vezes silenciado, possa expor aspectos de sua vida relacionados com a maternidade.

\subsubsection{História oral temática}

Nesta pesquisa, dentre os métodos e técnicas de pesquisa social, optamos pelo uso da História Oral, por este ser o método que melhor se adequava ao objetivo do estudo, pois "uma vez que a experiência de vida das pessoas de todo o tipo pode ser utilizada como matéria-prima, a história ganha nova dimensão" (THOMPSON, 1998, p. 25).

A história de vida no contexto da pesquisa social "tende a romper com a ideologia da biografia modelar de outras vidas, para trabalhar os trajetos pessoais no contexto das 
relações pessoais e definir-se como práticos das relações sociais" (CHIZZOTTI, 2000, p. 96).

A história de vida pode ser definida como "o relato de um narrador sobre a sua existência através do tempo, tentando reconstituir os acontecimentos que vivenciou e transmitir a experiência que adquiriu" (QUEIROZ, 1988, p. 20).

A história de vida gira em torno do indivíduo com sua subjetividade, e a constituição de suas qualidades o marca como um sujeito distinto dos demais de seu grupo, e da sociedade. No entanto, esse indivíduo recebe influência do modo de vida e do meio social, sendo sua personalidade o resultado da interação dele com seu ambiente social, assim a história de vida pode captar o que acontece no entrelaçamento da vida do sujeito com o social (QUEIROZ, 1988).

Uma história oral de vida não tem necessariamente que iniciar com a data de nascimento do sujeito da pesquisa, "o destaque é logo colocado sobre o espaço social, sobre um fato social, que condiciona a existência individual" (CIPRIANI, 1988, p. 118). Utilizar a história oral com objetivos sociais e pessoais esclarecedores é possível devido à natureza dessa abordagem, pois trata-se de compreender as histórias de vida individuais, e todas as vidas são interessantes. Seu objetivo é analisar o indivíduo social, "para chegar, na medida do possível, à 'verdade' das razões, dos valores e dos modelos que preparam o comportamento na sociedade" (CIPRIANI, 1988, p. 135).

Seu fundamento encontra-se baseado na fala, e não na escrita, que é mais exigente e restritiva; ela é edificada em torno de pessoas, propiciando contato e compreensão entre classes sociais e entre gerações (THOMPSON, 1998).

A primeira experiência da história oral como atividade organizada se deu em 1947, quando o professor Allan Nevis lançou o The Oral History Project da Universidade de Columbia. No Brasil, uma das primeiras experiências com história oral ocorreu em 1971, em São Paulo, no Museu da Imagem e do Som, cujo uso vem se ampliando, sendo inegável o interesse que a história oral vem despertando no pesquisador brasileiro (FREITAS, 1998, MEIHY, 1996). 
[...] a história oral implica uma percepção do passado como algo que tem continuidade hoje e cujo processo histórico não está acabado. A presença do passado no presente imediato das pessoas é razão de ser da história oral. Nesta medida, a história oral não só oferece uma mudança para o conceito de história, mas, mais do que isso garante sentido social à vida de depoentes e leitores que passam a entender a seqüência histórica e a sentirem-se parte do contexto em que vivem (MEIHY, 1996, p. 10).

Segundo Thompson (1998) a história oral

[...] torna possível um julgamento muito mais imparcial: as testemunhas podem, ser convocadas também entre as classes subalternas, os desprivilegiados e os derrotados. Isso propicia uma reconstrução mais realista e mais imparcial do passado, uma contestação ao relato tido como verdadeiro. Ao fazê-lo, a história oral tem um compromisso radical em favor da mensagem social da história como um todo (THOMPSON, 1998, p. 26).

Encontramos três possibilidades no uso da história oral, sendo, a história oral de vida, tradição oral e história oral temática. A história oral de vida trata da narrativa do conjunto da experiência de vida de uma pessoa, formando o retrato oficial do depoente que tem maior liberdade para dissertar o mais livremente possível sobre sua experiência pessoal. A tradição oral trabalha com a permanência dos mitos, com a visão de mundo de comunidades, busca explicações sobre a origem dos povos, crenças, rituais entre outras coisas (MEIHY, 1996).

A história oral temática aproxima-se das soluções comuns e tradicionais dos trabalhos de análise de diversas áreas do conhecimento. Ela parte de um assunto específico, definido anteriormente e se compromete com o esclarecimento ou opinião do entrevistador sobre algum evento específico, sua objetividade é direta. É a narrativa de uma versão de fatos vividos ou presenciados, portanto os detalhes da vida pessoal do narrador/entrevistado apenas interessam na medida em que revelam aspectos ligados ao tema pesquisado (MEIHY, 1996).

Para a produção das informações necessárias a este estudo, elegemos a história oral temática como nosso referencial metodológico. A história de vida temática dá ênfase à determinada etapa ou setor da vida da pessoa, assim sendo, ela nos permitirá obter informações sobre uma determinada etapa da vida das mulheres colaboradoras da pesquisa. 
Dessa forma, a história oral temática é a que melhor se aplica à investigação proposta, visto que nos permitirá estudar o evento relacionado com a maternidade na adolescência e as situações referentes aos processos de socialização dessa mulher e da maternidade como experiência do grupo social pesquisado.

5.2.2 A entrevista como recurso para coleta dados

Como técnica de coleta de informações acerca da história oral das mulheres estudadas, utilizamos a entrevista já preconizada como instrumento de eleição para colher a história oral. Segundo Thompson (1998, p. 271), “uma entrevista não é um diálogo, ou uma conversa. Tudo o que interessa é fazer o informante falar".

Gil (1999, p. 117) oferece-nos a seguinte definição para entrevista: “[...] técnica em que o investigador se apresenta frente ao investigado e lhe formula perguntas, com o objetivo de obtenção de dados que interessam à investigação".

Segundo Gil (1999), as entrevistas podem ser classificadas em informal, focalizadas, por pautas e formalizadas. Valles (1999) apresenta uma classificação equivalente, modificando a nomenclatura, que são quatro modalidades principais: informal, baseada em um guia, abertas e fechadas.

Neste estudo, optamos pela entrevista por pauta, pois apresenta certo grau de estruturação, caracterizada pela preparação de guia de temas a tratar, ou seja, uma relação de pontos de interesse que o entrevistador vai explorando ao longo da entrevista. " $O$ entrevistador faz poucas perguntas diretas e deixa o entrevistado falar livremente na medida em que se refere às pautas assinaladas" (GIL, 1999, p. 120). 
Acreditamos que com esta pesquisa poderemos melhor compreender as questões sobre a ocorrência da maternidade durante a adolescência e as suas conseqüências, em um grupo de mulheres de um extrato social menos favorecido econômica, cultural e socialmente da cidade de Maceió. O conhecimento derivado desta pesquisa nos dará oportunidade para entender a construção da maternidade entre estas mulheres.

\subsubsection{A escolha do local de estudo}

Este trabalho foi desenvolvido com mulheres assistidas pela Unidade de Saúde da Família, da Secretaria Municipal de Saúde de Maceió, situada na área vicinal da Universidade Federal de Alagoas - UFAL (figura 1).

Esta unidade iniciou suas atividades, em 1997, para atendimento do Programa de Saúde da Família e, até o ano de 2001 encontrava-se sob a responsabilidade gerencial do Pólo de Capacitação em Saúde da Família de Alagoas. Compreendia uma unidade docenteassistencial, com objetivos de desenvolver práticas em saúde na área da assistência, ensino e pesquisa. Nossa participação nas atividades desenvolvidas nesta Unidade ocorreu no período de 1997 a 1999, e em 2001 desenvolvemos a investigação sobre gravidez na adolescência, sendo que um dos objetivos era identificar entre as gestantes cadastradas por esta Unidade, no ano de 1999, aquelas que tiveram sua primeira gravidez entre 10 e 19 anos de idade e assim verificar a magnitude dessa ocorrência nessa faixa etária.

Um dos focos de atenção desta unidade é o Programa de Atenção Integral à Saúde da Mulher - PAISM, cuja ênfase encontra-se no ciclo gravídico-puerperal que, além das práticas assistenciais dirigidas a essa fase da vida das mulheres, privilegia a formação de vínculo entre as usuárias do serviço e seus profissionais de saúde.

Nossa participação no desenvolvimento das ações junto a esta unidade esteve relacionada à assistência como responsável pela consulta de enfermagem no atendimento pré-natal e no período puerperal e favoreceu nossa inserção na comunidade, permitindo a realização do estudo desenvolvido no mestrado. Com o vínculo estabelecido nesse dois 
momentos junto a essa população, foi possível retornar à comunidade visando ao desenvolvimento deste estudo.

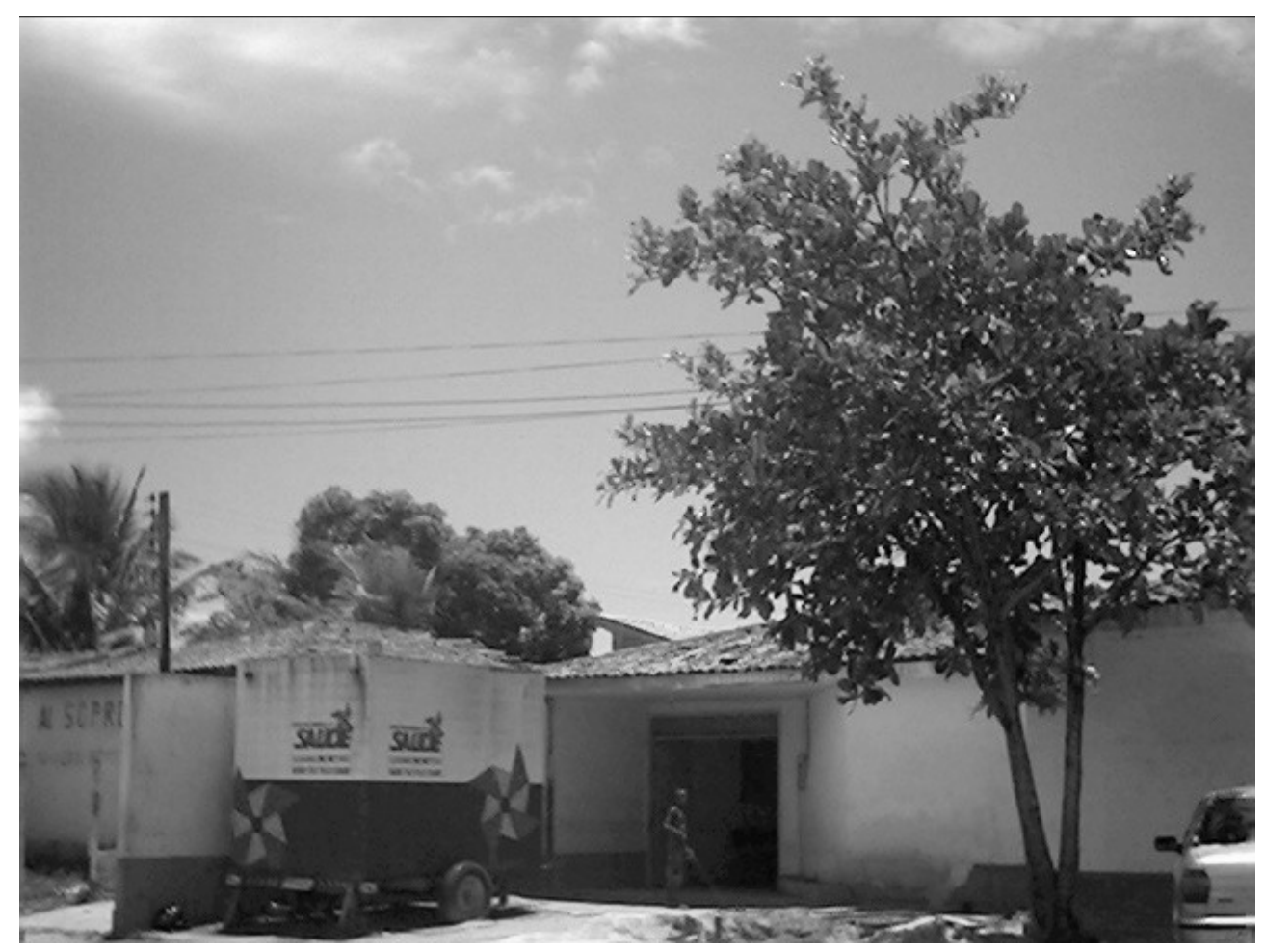

Figura 1. Unidade de Saúde da Família Frei Damião

\section{O local de estudo}

O local onde realizamos o estudo situa-se na área vicinal do Campus da UFAL, mais precisamente no Bairro Benedito Bentes, situado ao norte, em uma das regiões periféricas da cidade de Maceió. A área é composta pelos conjuntos habitacionais "Frei Damião", "Benício Mendes de Barros" e "Geraldo Bulhões", nos quais reside uma população urbana de baixa renda.

Os três conjuntos residenciais estão localizados na região norte da cidade de Maceió, capital do estado de Alagoas, cidade de porte médio com 797.759 habitantes (IBGE, 2000). Estado este que se encontra localizado na região Nordeste do Brasil.

Essa condição pode ser vista por meio da análise da situação econômica de Alagoas pelo resultado do PIB per capita comparando com o do Brasil. Alagoas de acordo com 
dados do IBGE (2000) tem uma das menores rendas per capta do país situando-se em 1999, em $24^{\circ}$ lugar entre os 27 estados da União com 2,275 reais. A taxa de crescimento do PIB per capta, de Alagoas, entre os censos de 1991 e 2001 foi de 1,3, ficando em $21^{\circ}$ lugar. Sua taxa de desemprego estava na ordem de 13,7 em 1999, sendo o $24^{\circ}$ estado em maior taxa de desemprego. A taxa de analfabetismo é a maior dos estados, sendo o feminino $41,49 \%$ e o masculino 46,48\%, apesar de que a taxa de analfabetismo em Maceió apresentou uma redução entre os dois últimos censos passando de 35,64\%, em 1991 para $28,51 \%$, no ano de 2000 .

Assim acreditamos que as circunstâncias sociais da região interferem no consumo de bens e serviços, tais como alimentos, habitação (higiene e saneamento), assistência à saúde e educação (figura 2).

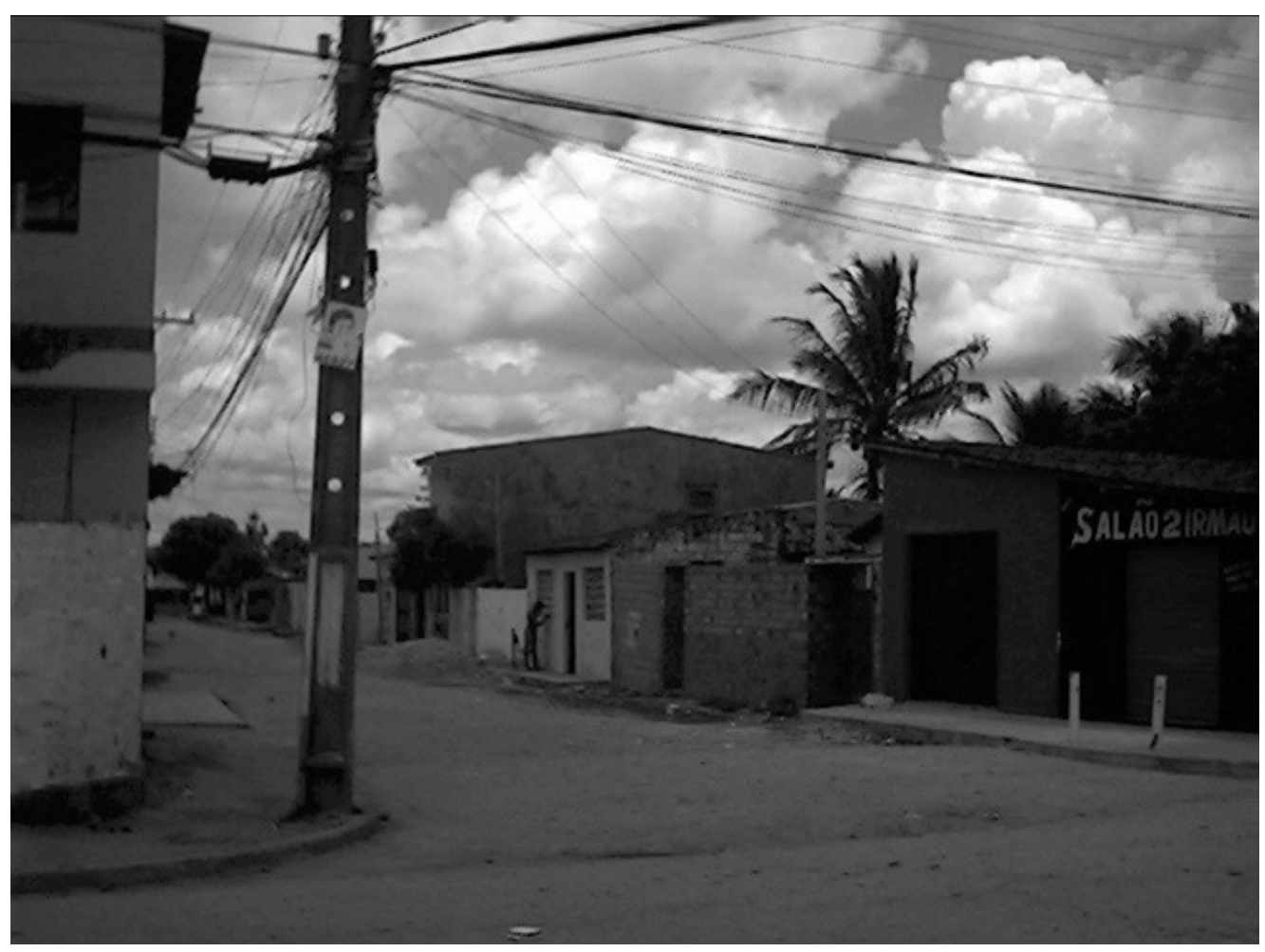

Figura 02. Conjunto Frei Damião

Os conjuntos habitacionais só têm pavimentação na rua principal, são servidos por água encanada oriunda de um poço artesiano que não recebe tratamento prévio, como fluoretação e cloração, antes de ser distribuída para as residências (figura. 3). As instalações sanitárias estão ligadas à rede geral ou às fossas sépticas. A coleta de lixo é realizada pelo serviço público municipal por meio de caminhões-caçamba que fazem a 
coleta em dias e horários prefixados, embora se observe em algumas ruas a carência na manutenção da limpeza das áreas públicas. A destinação das águas servidas, ou seja, aquelas utilizadas dentro das casas, corre a céu aberto.

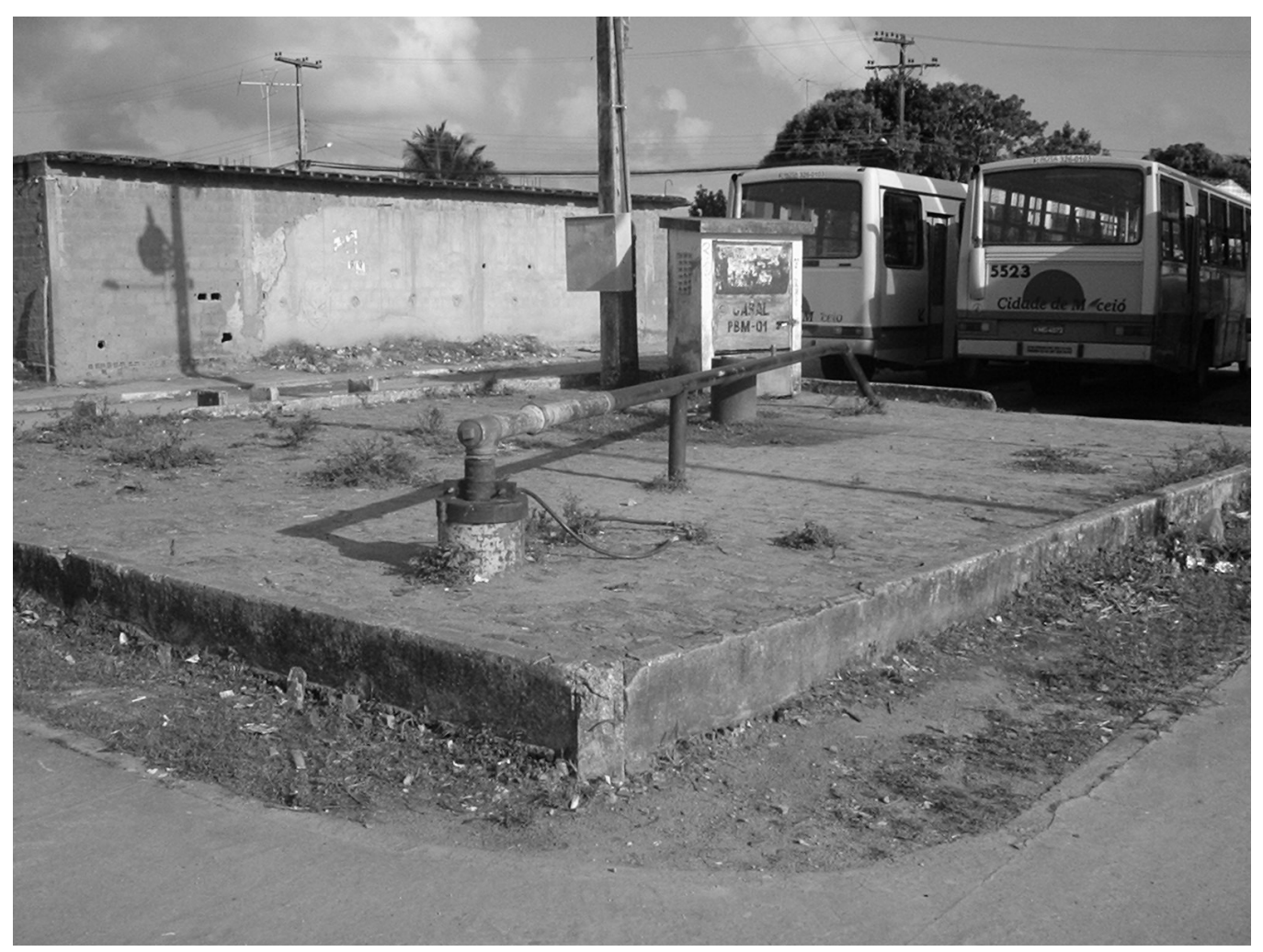

Figura 03. Poço artesiano do conjunto Frei Damião. Maceió/Al

Outra característica desta comunidade é a invasão de áreas de preservação natural dos conjuntos residenciais. Algumas destas áreas fazem limite com regiões de $\operatorname{grotas}^{1}$ que

\footnotetext{
${ }^{1}$ Grotas: são grandes áreas de depressão ou vales profundos, abaixo do limite da superfície do terreno.
} 
pelas características geográficas do terreno dificultam ou impedem a implantação de infraestrutura, de saneamento básico e de água tratada. (figura 4).

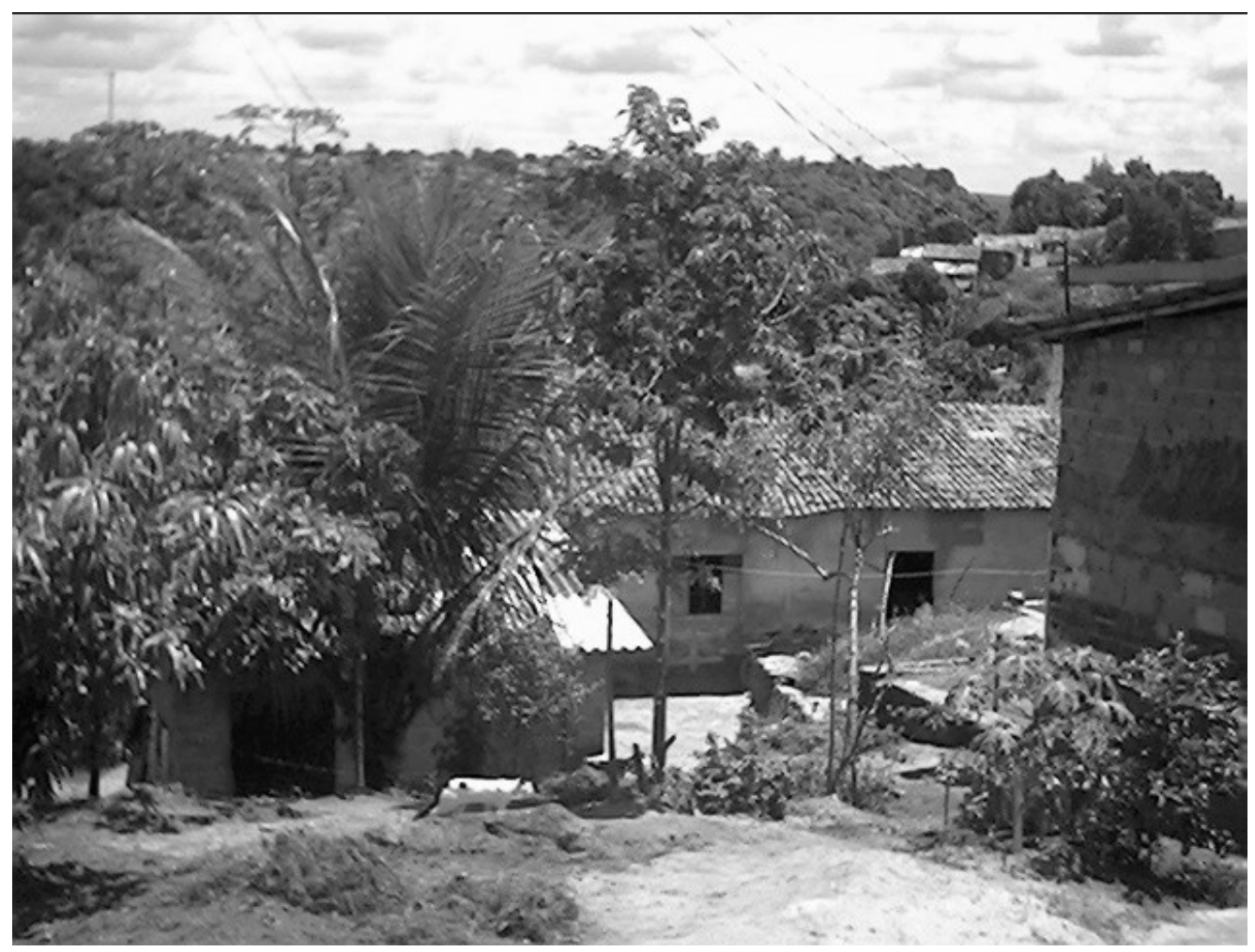

Figura 04. Área verde do conjunto Frei Damião, início de uma grota

\subsubsection{Aspectos éticos}

O Projeto foi aprovado pela Secretaria Municipal de Saúde de Maceió, a qual a Unidade de Saúde da Família está integrada. Após foi encaminhado para ser submetido à 
análise e aprovação pelo CEP - Comitê de Ética em Pesquisa da Escola de Enfermagem de Ribeirão Preto da Universidade de São Paulo, pois de acordo com a Resolução 196/96 do Conselho Nacional de Saúde, trata-se de uma pesquisa envolvendo seres humanos. O projeto foi aprovado e encontra-se registrado no protocolo número 0308/2002 (CEP EERP/USP, 1999, anexo 1).

A coleta de dados foi realizada após o consentimento verbal e consentimento escrito por meio de assinatura do Termo de Consentimento Livre e Esclarecido (apêndice B), tendo sido assinado em duas vias, uma para o arquivo da pesquisadora e outra entregue para a mulher, colaboradora da pesquisa.

\subsubsection{Escolha das mulheres para a pesquisa}

$\mathrm{Na}$ história oral temática, o (a) pesquisador (a) pode selecionar precisamente a quem vai entrevistar, assim sendo procuramos traçar um perfil das mulheres que fizeram parte como colaboradoras deste estudo. Esta escolha nos possibilitou revelar a experiência delas em relação à maternidade na adolescência.

A escolha das colaboradoras para participar desta pesquisa foi realizada a partir do grupo de mulheres que fizeram parte do estudo para a dissertação de mestrado, atendidas pelo PSF, das quais foi possível identificar 72 mulheres na faixa de 20 a 24 anos de idade, que estariam em condições de serem incluídas no estudo.

Assim, para inclusão das mulheres como colaboradoras da pesquisa, estabelecemos três critérios básicos:

- Mulheres residentes nos conjuntos Frei Damião, Benício Bentes e Geraldo Bulhões, da periferia da cidade de Maceió, capital do estado de Alagoas, situada na região Nordeste do país (figura 5).

- Mulheres que engravidaram pela primeira vez quando adolescentes, ou seja, com idade entre 10 e 19 anos. 
- Mulheres que, no momento da pesquisa, eram adultas jovens, com idade entre 20 e 24 anos.

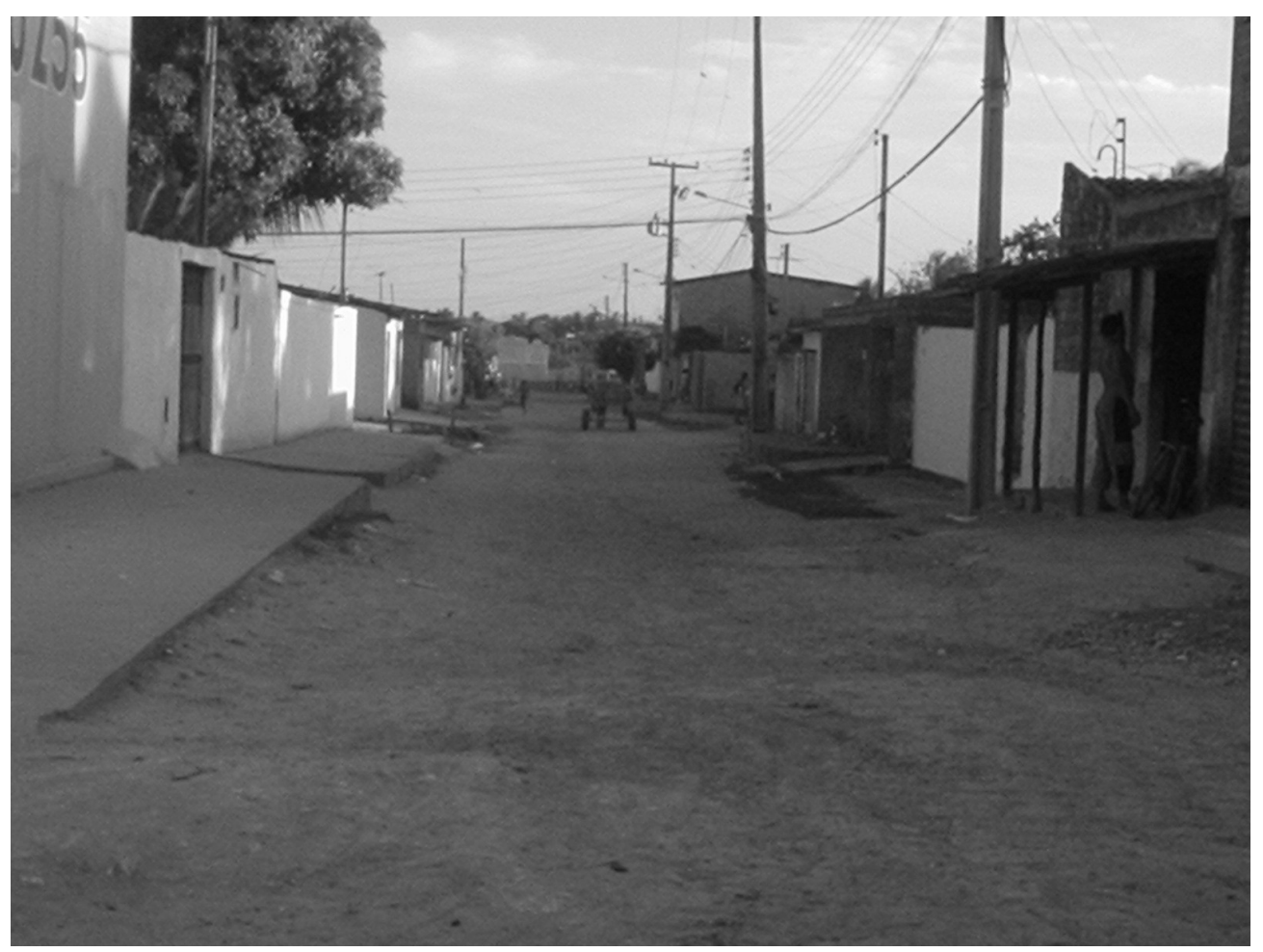

Figura 05 Rua do Conjunto Frei Damião

Após discussão e apresentação do estudo junto ao Diretor da Unidade de Saúde da Família, às enfermeiras e aos agentes comunitários de saúde da unidade, buscamos identificar, junto aos agentes, as mulheres que ainda residiam na comunidade, sendo que $27(37,5 \%)$ haviam se mudado da área, restando, portanto, 45 (62,5\%) mulheres na faixa de idade escolhida, sendo as entrevistas realizadas com $14(31,1 \%)$ das mulheres.

\section{Seleção das mulheres para participarem do estudo}


A seleção das mulheres para participarem do estudo foi intencional, fazendo parte dela apenas as mulheres que atendiam aos critérios de inclusão, ou seja, com idade entre 20 e 24 anos, formando um grupo geracional. Esse grupo reúne um conjunto de mulheres nascidas em um mesmo intervalo de tempo, entre 1976 e 1980, eram residentes na área onde foi realizada a pesquisa e cadastradas pela unidade de atenção à saúde da família.

Nesta pesquisa, a idade foi um ponto importante para entender a organização social deste grupo de mulheres, pois as idades definem "posições e situações em todas as sociedades, em variados graus de formalização e reconhecimento institucional" (MOTTA, 2003, p. 4).

Assim, esse foi o argumento utilizado para realizar esta pesquisa com um grupo de mulheres que tiveram a experiência de serem mães em uma mesma faixa de idade, ou seja, na pré-adolescência e adolescência, com idades que variaram de 14 a 19 anos, e que, no momento da pesquisa também se encontravam em uma mesma faixa de idade, definida pela OMS como juventude, que compreende as idades de 15 a 24 anos (OMS, 1986; 1989).

Como a pesquisa qualitativa preocupa-se com a realidade dos sujeitos dentro do grupo a que estão vinculados, entrevistamos 14 mulheres na faixa de idade de 20 a 24 anos. $\mathrm{O}$ número de mulheres para participar da pesquisa não foi definido previamente, ele foi estabelecido a partir do processo de saturação das informações coletadas.

Entre as mulheres contatadas para participarem da pesquisa, houve a exclusão de quatro delas, sendo que uma se encontrava ainda com 19 anos, duas não aceitaram participar logo no primeiro contato, e uma que havia aceitado participar da entrevista num primeiro momento, não foi entrevistada, porque estava grávida, e no dia marcado para a entrevista não estava em casa e em outra visita, já tendo dado à luz não quis mais participar. A participação que obtivemos mostra uma boa disponibilidade das mulheres da comunidade em colaborar com estudos dessa natureza.

5.2.6 Coleta dos dados 
As entrevistas aconteceram segundo a conveniência da entrevistada, em local onde ela se sentia à vontade. Em duas entrevistas, os companheiros estavam presentes, fato que não foi considerado obstáculo para a realização das mesmas. O papel do entrevistador foi mediar e apontar situações pertinentes ao objetivo da pesquisa, para que pudessem ser aprofundadas.

Alguns dados colhidos foram objetivos, como: idade, idade da primeira gravidez, escolaridade, estado civil, número de parceiros, ocupação, e também ocupação de seu parceiro, que foram complementados com dados subjetivos que diziam respeito a suas atitudes, valores e opiniões.

A maioria das entrevistas aconteceu em duas oportunidades (janeiro e fevereiro de 2003 e outubro e novembro do mesmo ano), durando em média 45 minutos aproximadamente. As duas entrevistas tiveram como objetivo coletar informações sobre o objeto de estudo, não tendo a característica de apenas complementar as informações ausentes, mas de refazer o depoimento, pois acreditávamos que um segundo encontro seria marcado por maior complexidade e novos relatos e aprofundamentos do que foi relatado, objetivo que em nossa avaliação foi alcançado.

Antes da entrevista propriamente dita, realizamos uma visita domiciliar preliminar, quando explicamos de maneira sucinta e clara o tema do nosso projeto, objetivo e finalidade da pesquisa, informações que desejava obter, em um entendimento preparatório com as mulheres a serem entrevistadas. Era também esclarecida de como seria sua participação, reforçando a colaboração espontânea, ficando a seu critério querer ou não participar, como também de se retirar da pesquisa durante a realização da mesma. Nesse encontro foi garantida a decisão das mulheres quanto ao seu anonimato nos resultados da pesquisa, por se tratar das histórias de suas vidas, e foi dada às mulheres a liberdade de escolherem um nome pelo qual foram identificadas.

$\mathrm{Na}$ escolha do local e horário da entrevista, também marcada nesta primeira visita, foi considerada a preferência da entrevistada. Assim a primeira entrevista de três mulheres ocorreu na unidade do PSF e as outras em seus domicílios. Todas as segundas entrevistas, aconteceram nos seus domicílios. 
Consideramos que a casa das depoentes foi o local em que as coletas de dados foram mais enriquecedoras, pois permitiram registrar informações acerca das características do local onde elas habitavam, apesar de existirem interferências familiares, das crianças ou mesmo de visitas e ruídos.

Nos casos em que não foi possível utilizar o domicílio pela falta de privacidade ou pelo desejo da mulher, a entrevista foi realizada na unidade de saúde, tendo sido marcados hora e dia adequado para a realização da mesma, conveniente para a depoente e a entrevistadora, sendo que, na visita domiciliar, utilizada como primeiro contato para esclarecimento da investigação, houve consulta sobre interesse em participar da mesma, a solicitação de consentimento e fez-se registro sobre os aspectos do domicílio.

Para a realização da entrevista, foi definida uma pergunta desencadeadora que foi Conte-me como foi para você ter engravidado com $\mathbf{X X}$ anos? - (sendo que $\mathbf{X X}$ era a idade de ocorrência de sua primeira gravidez). Pensamos em evitar a palavra adolescência - pois ela poderia desencadear uma posição de defesa, visto que o termo gravidez na adolescência é utilizado de uma maneira generalizada para se definir uma situação-problema.

As entrevistas transcorreram de uma maneira bastante amigável, com a interferência da pesquisadora na condução do depoimento, através de perguntas encadeadoras a partir das declarações das depoentes. Foi necessário, durante as entrevistas, usar técnicas de incentivo para com as nossas colaboradoras tais como: silêncio, animação e elaboração de perguntas, reafirmação e repetição de respostas e mudança de tema.

Para Thompson (1998), é de pouca importância entrevistar pessoas cujas lembranças não sejam claras, ou que sejam muito tímidas ou retraídas para falar sobre suas experiências, assim sendo nos colocamos na posição de uma boa ouvinte para que a mulher colaborasse contando sua história, pois várias de nossas depoentes apresentavam alguma dificuldade em se expressar e, assim sendo, conseguimos que elas pudessem ser uma auxiliar ativa.

A entrevista foi registrada, por gravação com uso de um microfone externo, o que deu maior liberdade para a depoente e melhor controle do aparelho pela pesquisadora. A gravação teve a vantagem de conservar com precisão a linguagem usada pela mulher, suas 
pausas, modulações de voz, e a seqüência de seu pensamento. Foi feito, também, um diário de campo onde registrávamos informações sobre o contexto da entrevista que não foram contempladas na gravação, sendo estes registros feitos, logo após a entrevista. Durante as mesmas buscamos aprofundar temas como: escolaridade; família; projetos de vida; vida sexual e reprodutiva.

As fitas foram etiquetadas e catalogadas com: nome, número e ordem de realização (Apêndice A), e a gravação ouvida com o objetivo de conferir se as informações obtidas eram suficientes ou se ainda era necessário complementá-las.

Foram realizadas duas entrevistas com cada mulher entrevistada com exceção de quatro delas cujas narrativas ocorreram em um único encontro. Diversas foram as razões: 1. Mariana estava separada do companheiro na primeira entrevista e na segunda havia reatado o mesmo e não quis dar nova entrevista; 2. Orquídea não foi localizada, pois se separou do companheiro e estava na casa do pai; 3 Caroline concordou em participar, porém na primeira entrevista não se encontrava em casa no dia da entrevista e mesmo após várias visitas não foi localizada, pois tinha viajado por problemas familiares; 4. Isadora não havia sido contatada na primeira entrevista, mas achamos importante a inclusão de mais mulher na investigação.

\subsubsection{Análise dos dados}

A natureza desta pesquisa é qualitativa, tendo em vista seu objeto de estudo e objetivo proposto, que buscou apreender "[...] o universo de significados, motivos aspirações, crenças, valores e atitudes" que "não podem ser reduzidos à operacionalização de variáveis" (MINAYO, 2000, p. 21-22).

O mais importante da metodologia qualitativa é a análise que reúne a "especificidade biográfica dos sujeitos dentro de um contexto sociocultural com a busca de interpretação dos seus discursos e práticas a partir de suas 'certezas', ambigüidades e contradições" (DESLANDES e ASSIS, 2002, p.213). 
$\mathrm{Na}$ análise do material recolhido buscou-se atingir a três objetivos: a) ultrapassagem da incerteza; b) enriquecimento da leitura; c) integração das descobertas. A análise do material possui três finalidades: a primeira é heurística, pois se insere no contexto de descobertas das pesquisas; a segunda é a de administração de provas, que confirma ou levanta hipóteses e a terceira é a de ampliar a compreensão de contextos culturais com significações que ultrapassem o nível espontâneo das mensagens (MINAYO, 1996).

A interpretação dos resultados se deu tendo como referência as falas das mulheres colaboradoras desta investigação, a partir das suas histórias orais temáticas. Nesse processo tornou-se necessário fragmentá-las, assim recortamos as passagens que diziam respeito aos objetivos do estudo. As etapas deste processo foram:

- Transcrição das entrevistas gravadas em fitas, anotando nas fichas de transcrição o lado da fita correspondente. Este foi o momento em que passamos do estágio oral para o escrito. Foram transcritas 24 fitas, que resultou em 209 páginas digitadas, em folha sulfite, tamanho A4, letra Times New Roman, tamanho 12 e espaço 1,5 cm, respeitando a forma como se encontravam gravadas.

- Conferência das transcrições com as fitas gravadas.

- Complementação do conteúdo das entrevistas através dos registros do diário de campo.

- Estabelecimento de contato com o material através da leitura do conteúdo.

- "Re-construção" do texto através da supressão das perguntas que foram feitas, deixando apenas a fala do narrador, personagem principal de sua história. A história oral foi reorganizada por ordem cronológica de acontecimentos, buscando dar uma lógica e clareza ao texto, retirando informações que não estivessem de acordo com os objetivos do estudo. Nesta etapa, escolheu-se uma frase que correspondia ao tom vital da história que foi utilizada como epígrafe que se encontra no início da apresentação da mulher entrevistada. 
- "Re-criação" da narrativa através dos recortes na história, codificando o material na busca de núcleos de pensamento, colocando os parágrafos na ordem de interesse do autor. A transcrição do texto foi ser legitimada pelas mulheres entrevistadas, sendo que o texto final, ou seja, a narrativa é de autoria da pesquisadora, conferido e aprovado pela depoente, porém procuramos manter a característica de expressão das colaboradoras. Após esta etapa elaboramos um esboço das histórias narradas pelas mulheres (apêndice C). 
- Análise da evidência oral.

Neste estudo, a maternidade na adolescência foi estudada como um fato social, procurando interpretar trechos ou narrativas das histórias selecionadas, tendo como referencial a teoria de gênero e buscando compreender construção social da maternidade.

Escolhemos para análise das informações coletadas a análise temática, que segundo Minayo (1996) "consiste em descobrir núcleos de sentido que compõem uma comunicação cuja presença ou freqüência signifiquem alguma coisa para o objetivo visado" (p.209), para a qual importa mais a expressão verbal, a compreensão simbólica de uma realidade a ser conhecida.

Para a operacionalização dessa análise seguimos, basicamente, três etapas: préanálise; exploração do material e tratamento dos resultados obtidos e interpretação (MINAYO, 1996).

\section{Pré-análise:}

Esta se deu após a construção das narrativas. Consistiu em leituras do material de forma a nos sentirmos bem familiarizados com o conteúdo, fato que se iniciou na fase anterior.

As narrativas consistem em reconhecer a mulher e a maternidade, a partir da sua própria compreensão e interpretação. A técnica adotada possibilita um conhecimento mais íntimo dessas mulheres, de seus sentimentos e desejos, assim como uma visão indireta e subjetiva da dinâmica familiar e a relação com seus parceiros.

\section{Exploração do material:}

Iniciamos a exploração do material com a redução das informações contidas nas narrativas, identificando os fragmentos do texto que tinham algum significado com o objeto de nosso estudo, ou seja, começamos uma primeira redução das informações brutas que são as narrativas, selecionando citações.

Quando da seleção das citações, fomos definindo palavras que denominamos de codificação com o objetivo de simplificar o conteúdo das citações. Cada citação pode 
conter mais de um código, assim como um código pode ser referido em mais de uma citação.

Após proceder ao recorte e à codificação das narrativas, realizou-se leitura do mesmo e a definição dos núcleos de sentido, ou seja, das unidades de significação. Inicialmente estabelecemos os seguintes núcleos de sentido: escolaridade e gravidez, família e o apoio na formação da mulher, iniciação sexual, papel feminino na maternidade na adolescência, papel masculino na maternidade na adolescência, projetos e desejos, sentimentos frente ao contexto de vida, trabalho.

Posteriormente analisamos os significados dos núcleos e recortes das narrativas, pois realizar uma análise temática consiste em descobrir temas adequados ao estudo. Assim sendo, os núcleos de sentidos foram classificados e agregados em duas áreas temáticas, cinco categorias para cada uma e 22 subcategorias.

Depois analisando estas categorias observamos que elas poderiam ser reagrupadas e definimos quatro categorias e suas respectivas subcategorias:

\section{- CONHECENDO AS MULHERES ESTUDADAS}

Categoria 1. Contexto social. Contém três subcategorias: família de origem, escolaridade, trabalho antes da gravidez.

Categoria 2. Sexualidade e reprodução. Abrange duas subcategorias: namoro e primeira relação sexual, uso de contraceptivo.

\section{- EVIDENCIANDO AS HISTÓRIAS DA MATERNIDADE NA ADOLESCÊNCIA}

Categoria 3. Maternidade na adolescência. Identificamos, também, três subcategorias: maternidade na adolescência, sentimentos vivenciados com a maternidade, reações frente à descoberta da gravidez.

Categoria 4. Conseqüências da maternidade na adolescência. Inclui quatro subcategorias: infidelidade masculina, violência e separação do parceiro, dependência do parceiro, o cuidado dos filhos, projetos de vida. 


\section{Tratamento dos resultados obtidos e interpretação}

Nesta etapa realizamos uma análise qualitativa dos resultados obtidos, buscando interpretar os significados encontrados da maternidade com a questão estudada nesta pesquisa.

Esta análise consiste em reconhecer a mulher e a maternidade, a partir da sua própria compreensão e interpretação. A técnica adotada possibilita um conhecimento mais íntimo dessas mulheres, de seus sentimentos e desejos, assim como uma visão indireta e subjetiva da dinâmica familiar e a relação com seus parceiros. 


\section{ANÁLISE DAS NARRATIVAS}

Neste capítulo iremos analisar o conteúdo das narrativas, sobre a maternidade na adolescência, de 14 mulheres com idade entre 20 e 24 anos que foram mães na adolescência. Entre as mulheres do estudo, seis tinham entre 20 e 22 anos e oito entre 23 e 24 anos de idade.

Entendemos ser importante compreender as questões relacionadas à gravidez na adolescência, sua subjetividade e relações de gênero, ou seja, as relações existentes entre as mulheres envolvidas neste estudo e os seus parceiros, e a construção social da maternidade. No processo das entrevistas, a figura paterna foi trazida para o relato, fornecendo subsídios para identificar como se dá esta relação entre a maternidade e a paternidade, que auxiliou numa discussão mais ampla sobre a temática e, também, possibilitou identificar possibilidades de transformação dessas relações sociais.

Em nossa compreensão, a maternidade é um importante tema de estudo, sendo que a gravidez na adolescência deve ter sua discussão ampliada, evitando ficar apenas nas questões relacionadas aos aspectos sexuais, pois este fato faz parte da história do mundo e, portanto, também pode ser entendido como uma construção social estando envolvidas as questões de gênero. Trazer a discussão de tal fato, através de suas relações com os projetos de vida, com a educação sexual e com as condições de vida, incluindo acesso à educação formal, emprego, entre outros, é importante para sairmos da análise apenas biologizante desta ocorrência.

Além da história sobre a maternidade na adolescência, outras informações nos foram fornecidas que ajudaram a caracterizar o contexto social dessas mulheres, com destaque para nível de escolaridade, experiência de trabalho antes da gravidez e a 
configuração familiar, além de aspectos da sua vida sexual e reprodutiva como: iniciação sexual e uso de contraceptivos antes da primeira gravidez.

Antes da análise das narrativas apresentamos uma identificação com pontos que nos pareceram importantes de serem descritos e nossa percepção sobre os sentimentos e comportamentos apresentados durante a(s) entrevista(s). Antecedendo o início de cada descrição colocamos uma epígrafe, ou seja, o tom vital, que foi uma frase escolhida, dentro da narrativa, como um guia de sua história.

\subsection{IDENTIFICAÇÃO DAS MULHERES}

Cada mulher aqui apresentada é única e constitui um pequeno mundo, porém cada uma, também, proporciona uma visão da cultura e do meio ambiente em que elas estão inseridas, sendo as mesmas um reflexo do seu meio social e, desta forma, haveremos de procurar interpretar suas histórias tendo como pano de fundo seu contexto de vida.

Abaixo apresentaremos um perfil geral das quatorze mulheres entrevistadas, na seqüência em que os depoimentos foram coletados e com os nomes que elas escolheram para identificar suas histórias. 
Quadro 1- Perfil das mulheres que participaram do estudo ${ }^{1}$

\begin{tabular}{|c|c|c|c|c|c|c|c|}
\hline No. & $\begin{array}{c}\text { Pseudônim } \\
\text { o }\end{array}$ & $\begin{array}{c}\text { Idade na } \\
\text { ocasião da } \\
\text { entrevista }\end{array}$ & $\begin{array}{c}\text { Estado } \\
\text { civil } \\
\text { (atual) }\end{array}$ & $\begin{array}{l}\text { Escolaridad } \\
\text { e (anos de } \\
\text { estudo) } \\
\end{array}$ & Ocupação & $\begin{array}{l}\text { Idade da } \\
\text { primeira } \\
\text { gravidez } \\
\end{array}$ & $\begin{array}{c}\text { Número } \\
\text { de filhos } \\
\text { vivos } \\
\end{array}$ \\
\hline 1 & Orquídea & 23 & Solteira & 5 & $\begin{array}{c}\text { Dona de } \\
\text { casa }\end{array}$ & 16 & 3 \\
\hline 2 & Evelin & 23 & Marital & Nenhum & $\begin{array}{c}\text { Dona de } \\
\text { casa }\end{array}$ & 19 & 1 \\
\hline 3 & Maria & 21 & Solteira & 2 & $\begin{array}{c}\text { Dona de } \\
\text { casa }\end{array}$ & 15 & 2 \\
\hline 4 & Uliane & 20 & Solteira & 5 & $\begin{array}{l}\text { Dona de } \\
\text { casa e } \\
\text { vendedora } \\
\text { ambulante }\end{array}$ & 14 & 2 \\
\hline 5 & Taís & 24 & Marital & Nenhum & $\begin{array}{c}\text { Dona de } \\
\text { casa }\end{array}$ & 17 & 3 \\
\hline 6 & Tieta & 20 & Marital & 7 & $\begin{array}{c}\text { Dona de } \\
\text { casa }\end{array}$ & 17 & 2 \\
\hline 7 & Leônia & 22 & Solteira & 4 & $\begin{array}{c}\text { Dona de } \\
\text { casa }\end{array}$ & 14 & 5 \\
\hline 8 & Vitória & 24 & Casada & 8 & $\begin{array}{c}\text { Dona de } \\
\text { casa }\end{array}$ & 16 & 4 \\
\hline 9 & Aparecida & 23 & Marital & 2 & $\begin{array}{c}\text { Dona de } \\
\text { casa }\end{array}$ & 14 & 3 \\
\hline 10 & Vera & 22 & Marital & 5 & $\begin{array}{c}\text { Dona de } \\
\text { casa e } \\
\text { pensionista } \\
\end{array}$ & 17 & 2 \\
\hline 11 & Esmeralda & 21 & Marital & 2 & $\begin{array}{c}\text { Dona de } \\
\text { casa }\end{array}$ & 14 & 4 \\
\hline 12 & Mariana & 20 & Marital & 7 & $\begin{array}{c}\text { Dona de } \\
\text { casa }\end{array}$ & 19 & 1 \\
\hline 13 & Caroline & 23 & Marital & 5 & $\begin{array}{c}\text { Dona de } \\
\text { casa }\end{array}$ & 17 & 3 \\
\hline 14 & Isadora & 23 & Solteira & 8 em curso & $\begin{array}{c}\text { Dona de } \\
\text { casa e } \\
\text { diarista }\end{array}$ & 16 & 2 \\
\hline
\end{tabular}

\footnotetext{
${ }^{1}$ Quadro adaptado de Trezza, M.C. S.F. Construindo através da doença possibilidades de sua libertação para uma outra forma de viver: um modelo teórico representativo da experiência de pessoas que tiveram câncer. Rio de Janeiro. p. 267 (Tese de Doutorado) Escola de Enfermagem Anna Nery/UFRJ.
} 


\section{ORQUIDEA}

\section{"Faltou juízo, se eu tivesse mais juízo antes de ter tido esta criança, se tivesse mais cuidado, se eu tivesse pegado estudo, eu tava livre"}

Orquídea tem 23 anos, escolheu este nome por ser o de uma flor bonita, que amantes, namorados, maridos e apaixonados dão de presente. É solteira, teve três gravidezes. Na ocasião da primeira entrevista vivia em união consensual com o pai de seus filhos, porém quando fomos realizar a segunda entrevista ela havia se separado do parceiro. Segundo a agente de saúde, ela estava morando na casa de seu pai, mas não conseguimos localizar seu endereço, portanto participou de uma única entrevista. Não estudava e não trabalhava fora de casa. Residia na casa de seu parceiro, uma casa de alvenaria, de dois pisos, com a parte superior da construção por terminar. Era rebocada e pintada, no entanto, mal conservada, possuía sete cômodos compondo: três quartos, duas salas, uma cozinha e um banheiro. A entrevista aconteceu em um dos consultórios da Unidade do PSF, por ela achar que ali seria melhor. Durante a entrevista, ela se apresentava com o semblante sério, não sorria com facilidade, somente quando falava de alguma coisa relacionada a sexo, sexualidade dava uns risos. A sexualidade e o sofrimento estavam sempre presentes no seu relato, assim como elementos religiosos. Transparecia sentimentos de infelicidade e não-aceitação de si. Não conseguiu falar muito concretamente de sua gravidez e maternidade na adolescência. Algumas vezes apresentava contradição em seu relato, mostrando uma certa confusão em seus pensamentos.

\section{EVELIN}

\section{"Vou casar pra viver feliz, vou casar pra ter família, pra deixar de trabalhar nas cozinhas do povo"}

Evelin tem 24 anos, escolheu este nome por ser o nome de sua filha. É solteira, teve duas gravidezes, estava grávida de quatro meses na segunda entrevista. Antes evitava a gravidez com injeção contraceptiva, mas na primeira entrevista não estava tomando, pois como já fazia três anos que fazia uso deste método a médica suspendeu e não substituiu por outro método porque desejava uma nova gravidez. Não trabalha fora de casa, é analfabeta, não sabe nem assinar seu nome. Reside na casa de seu parceiro, o casal e sua filha, a mãe e 
duas sobrinhas dele, cuja casa é de alvenaria, rebocada e pintada com cinco cômodos: dois quartos, sala, cozinha e banheiro. A sogra recebe uma aposentadoria com a qual ajuda nas despesas da casa. A primeira entrevista aconteceu em um consultório da Unidade do PSF, por sugestão da mesma. A segunda entrevista aconteceu em seu domicílio, que estava sendo reformado (ampliado) apresentando um pouco de ruído e dessa forma ficamos na lavanderia. Durante as entrevistas, ela apresentava certa dificuldade em se expressar, não sabia avaliar suas expectativas, seus projetos de vida, falava rapidamente, mas se mostrava tranqüila, sempre sorridente. No primeiro momento, negou que havia tido experiência sexual antes de conhecer seu companheiro, depois falou dessa relação se referindo a ela, como algo “[...] triste, sem amor, sem nada...", na segunda entrevista falou sobre a violência sexual de que foi vítima com 13 anos de idade.

\section{MARIA}

"Só acho ruim porque não posso estudar, trabalhar essas coisas, só isso".

Maria tem 21 anos, escolheu este nome por ser o dela mesmo e porque segundo ela ninguém iria identificá-la. É solteira, teve quatro gravidezes, dois abortos, tem duas filhas do mesmo parceiro, estava grávida de oito meses na primeira entrevista, não trabalha fora de casa e não está estudando. Reside na casa de sua mãe com suas duas filhas, em uma casa de alvenaria, rebocada e pintada com cinco cômodos: dois quartos, sala, cozinha e banheiro. Aceitou participar do estudo, apesar de perguntar o que poderia dizer, ao que respondi que a experiência dela era importante para o estudo. A primeira entrevista aconteceu em um consultório da Unidade do PSF, por sugestão da mesma. Durante esta entrevista, ela se apresentou tranqüila, falando calmamente, demonstrando sentimentos de frustração e arrependimento, com o rumo que sua vida havia tomado. A segunda entrevista aconteceu em seu domicílio, na cozinha, com a presença da filha mais nova e da sua mãe que dormia em uma rede na sala. Nesta entrevista a mesma falou em tom baixo, como que não quisesse ser ouvida pela mãe e evitou falar detalhes dessa relação familiar, fato abordado durante a primeira. Os sentimentos apresentados eram os mesmos. Em uma das visitas para apresentar o projeto, sua mãe perguntou sobre a possibilidade da filha fazer laqueadura tubária, demonstrando claramente que gostaria que ela a fizesse para controlar a natalidade. 


\section{ULIANE}

“Engravidei aos 14 não foi uma coisa planejada, pois acho que ninguém engravida aos 14 planejando"

Uliane tem 20 anos, escolheu este nome por ser o nome que queria colocar em sua filha, mas o parceiro não deixou, assim resolveu colocá-lo aqui em sua história. É solteira, teve três gravidezes, um aborto, tem dois filhos, um menino e uma menina, viveu em união consensual com o pai de seus filhos, desde a gravidez até um mês antes da primeira entrevista. Não está estudando e no momento da segunda entrevista estava trabalhando como ambulante, vendendo "jogo de lençóis". Reside no fundo da casa de sua mãe com seus dois filhos em uma casa de alvenaria, rebocada e pintada. A mesma tem dois cômodos: quarto, sala que também serve de cozinha, usa o banheiro de uma casa que fica no mesmo terreno, onde morava sua avó, os utensílios de cozinha são lavados, fora da casa, no tanque de lavar roupa. A primeira entrevista que deveria ocorrer em um dos consultórios da Unidade do PSF por ela achar que ali teria menos interferência das crianças não aconteceu, pois no dia marcado não compareceu e disse que havia se esquecido, ao que marcamos outra. A segunda entrevista aconteceu em seu domicilio, na sala, com as crianças brincando lá fora e às vezes entravam e interrompiam. Durante as duas entrevistas, ela se apresentava tranqüila, falando calmamente, parecendo bem à vontade para contar sua história, apesar de na segunda entrevista nos pareceu um pouco mais segura. Quando falava da mãe, apresentava um certo distanciamento não deixando transparecer nenhum sentimento, porém quando falava do pai se mostrava mais solta e afetiva. Seus filhos estão presentes em quase toda a narrativa e também Deus.

\section{TAÍS}

"A minha mãe me abandonou, porque ela não me queria grávida dentro de casa, eu fiquei sozinha, o pai mesmo não quis nem saber" 
Taís tem 24 anos, escolheu este nome por ser o nome de uma personagem de novela da televisão com a qual as pessoas achavam que se parecia. É solteira, porém vive em união consensual, teve quatro gravidezes, três partos e um aborto, tem dois filhos vivos. Vive com seu parceiro, dois filhos e um cunhado em uma casa que pertence a sua sogra. A casa é de alvenaria, rebocada e pintada, com sete cômodos: três quartos, duas salas pequenas, uma cozinha e um banheiro. Não estudou e mal sabe escrever seu nome. Não trabalha fora de casa. As duas entrevistas aconteceram em sua casa. Na primeira entrevista, ela estava grávida. O parceiro e sua filha estavam presentes, mas isso não interferiu no desenvolvimento da mesma. Ele estava desempregado e a renda da família no valor de 200,00 reais vinha de sua mãe. Na segunda entrevista, as crianças estavam presentes, seu marido havia arrumado um emprego. Ela se apresentava, como na primeira entrevista, totalmente disponível para conversar. Aparentemente tranqüila, mostrando alguns risos nervosos, deixava transparecer um sentimento de solidão. Chegou a se emocionar até as lágrimas quando falou sobre sua primeira gravidez e sobre sua mãe.

\section{TIETA}

\section{"Passei a ser dona de casa e a responsabilidade era maior, deixei de curtir, ir pras} festas, deixei de brincar, deixei de muita coisa, eu não queria ter engravidado tão cedo"

Tieta tem 20 anos, escolheu esse nome, pois era o nome que sua mãe e sua tia lhe

chamavam, porque era muito sapeca. É solteira, porém vive em união consensual, teve duas gravidezes e tem duas filhas. Reside com sua família em uma casa que pertence a sua sogra. A casa é de alvenaria, rebocada e pintada, com cinco cômodos: dois quartos, sala, cozinha e banheiro. Estudou até a $8^{\text {a }}$ série do Ensino Fundamental, nunca trabalhou fora de casa. As duas entrevistas foram feitas no domicílio, a primeira na casa de sua avó, vizinha da sua mãe no conjunto Benício Mendes de Barros, que estava vazia e a segunda em sua casa no conjunto Frei Damião. Nas duas, suas filhas estavam presentes o que apesar de desviar um pouco a atenção não prejudicou o depoimento. Entre a primeira e a segunda, Tieta havia feito uma cirurgia para fazer uma laqueadura tubária. Na primeira entrevista, havia declarado sua vontade de fazer a cirurgia. Nas duas entrevistas encontrava-se disponível para conversarmos, apresentava-se tranqüila, porém algumas vezes tinha 
dificuldade de se expressar. Estava sempre sorridente, e não percebemos mudança em seu tom de voz durante a entrevista.

\section{LEÔNIA}

"Eu tinha uns 13 anos quando eu vim pensar mesmo de arrumar uma pessoa pra viver, pra casar mesmo [...] A cabeça foi mais de adolescente e não me preveni e engravidei

$\log \boldsymbol{\prime}^{\prime}$

Leônia tem 23 anos, escolheu seu próprio nome para identificar sua história, pois para ela muita gente tem este nome e não será reconhecida. É solteira, tem cinco filhos, viveu em união consensual com o pai de quatro de seus filhos durante sete anos. Realizamos duas entrevistas em sua residência. Na primeira entrevista, ela estava grávida e fazendo tentativas para abortar, pois não desejava este filho, apesar de estar separada de seu companheiro, não mantinha uma relação "estável" com o homem de quem havia engravidado. Realizamos nova visita uns quinze dias depois da primeira entrevista, quando ela me mostrou o resultado de um ultra-som que mostrava uma gravidez de 11,5 semanas. Ela havia tomado Cytotec e foi ao hospital com sangramento, porém o aborto não se efetivou. Na segunda entrevista, ela havia mudado de casa, para uma casa próxima à anterior que era de sua sogra, onde agora o pai de seus filhos estava residindo com sua nova companheira que estava grávida. Durante a entrevista se apresentava tranqüila, apesar dos problemas que estava vivenciando. Quando falava de ser mãe sempre apresentava um sorriso.

\section{VITÓRIA}

"Eu tentei evitar de todo jeito, mais só que não dava, pegava preservativo lá, mas ele não quer usar de jeito nenhum, com ele não dá certo sabe, ele é muito agoniado"

Vitória tem 23 anos, teve muita dificuldade em escolher um nome que identificasse sua história e acabou escolhendo o nome de sua filha mais nova, ao mesmo tempo em que dizia que este nome não tinha nada a ver com ela. Casada, tem quatro filhos, relatou ter 
tido um aborto pouco tempo antes da primeira entrevista e na segunda entrevista estava grávida de sete meses. As entrevistas foram feitas em seu domicílio, uma na área em frente a sua casa. Apesar de aceitar participar da pesquisa, se mostrava extremamente tímida, apática, com dificuldade de se expressar, parecia inibida, dando respostas curtas e tendo que ser estimulada todo o tempo. Não olhava nos meus olhos ao falar e muitas vezes desviava do assunto de que estávamos tratando, algumas vezes bastante era reticente, com muitos momentos de silêncio antes que ela falasse algo.Todavia consideramos seu depoimento importante para a investigação. Sua casa é de alvenaria tem cinco cômodos onde reside com seu esposo e seus filhos. A casa pertence a sua sogra e é uma pequena comunidade formada por quatro casas na área verde do conjunto Frei Damião, início de uma grota. Não trabalha fora de casa e também não está estudando, apesar de na primeira entrevista ter dito que voltaria a estudar naquele ano.

\section{APARECIDA}

\section{"Empatou minha vida, como eu digo hoje, que eu só vivi até ter a Bárbara, de lá pra cá eu não vivo para mim, vivo para eles"}

Aparecida tem 23 anos, escolheu este nome para identificar sua história, pois para ela é um nome de gente sofredora. É solteira, tem três filhos, vive em união consensual com o pai de seus filhos. Realizamos duas entrevistas em sua residência. Sua casa situa-se em uma das grotas do Frei Damião, a casa é de alvenaria, sem reboco, tem cinco cômodos, sala, dois quartos, cozinha e banheiro e é desprovida de móveis básicos. As entrevistas aconteceram conosco sentadas no solo da cozinha em cima de um cobertor que fazia o papel de tapete. Bastante receptiva para participar da pesquisa, estava sempre com um sorriso no rosto. Tranqüila e participante tem bastante desenvoltura ao falar. Não trabalha fora de casa e não estuda. Na primeira entrevista, apresentava o desejo de continuar os estudos, mas não enxergava nenhuma possibilidade de isso vir a acontecer, na segunda relatou que voltaria à escola. 


\section{VERA}

\section{"Tive um aborto e tenho três filhos, já é muito, é muito demais, tudo o que deixa empatado é demais"}

Vera tem 22 anos, escolheu este nome porque foi o primeiro que lhe veio à mente. É solteira, porém recebe uma pensão de seu primeiro companheiro que faleceu e com quem teve um filho. Atualmente vive em união consensual, tem três filhos vivos, teve quatro gravidezes. Foram realizadas duas entrevistas, na primeira seu companheiro, que tem uma deficiência na perna e estava desempregado, permaneceu na sala durante a entrevista, fazendo algumas intervenções sem atrapalhar o andamento da entrevista, na segunda ele havia arrumado um emprego de vendedor ambulante e estava trabalhando. Sua casa tem quatro cômodos e não tem acabamento. Seu filho mais novo estava com escabiose e apresentava algumas lesões infectadas na cabeça. Não estuda e não trabalha fora de casa. Durante a primeira entrevista, havia no quintal um grupo de pessoas tocando e cantando, o que significa que tivemos bastante ruído durante a gravação. Durante as entrevistas, aparentava tranqüilidade apesar de apresentar alguns sentimentos confusos e dificuldade de se expressar e as questões de saúde estavam bem presentes no depoimento.

\section{ESMERALDA}

"Ah! Eu me senti mais madura por ser mãe nova"

Esmeralda tem 20 anos, escolheu este nome por ser de uma personagem de novela da qual ela gostava, mas teve dificuldade de escolher um nome. Foram realizadas duas entrevistas uma na casa de sua mãe, nesta ela estava com um filho de 26 dias de vida e outra em sua residência.Vive em união consensual e mora com seu companheiro e seus quatros filhos, em uma casa com cinco cômodos. Apresenta certa timidez e muita dificuldade de se expressar apesar da disponibilidade em participar da entrevista. Foi necessário estímulo constante com diversas perguntas. Não trabalha fora de casa e não estuda. Na primeira entrevista, uma de suas irmãs estava na casa e algumas vezes participava, mas não interferiu no andamento do depoimento. 


\section{MARIANA}

\section{"Mudou tudo, até o meu jeito de pensar, porque antes eu só pensava em mim, agora eu penso mais nela do que em mim"}

Mariana tem 20 anos, escolheu este nome por achar que toda Maria é sofredora. Teve uma gravidez e tem uma filha. Realizamos apenas uma entrevista e naquela ocasião encontrava-se separada do pai de sua filha com quem viveu em união consensual. $\mathrm{Na}$ época de realizarmos a segunda entrevista, apesar de inicialmente ter aceitado colaborar com novo depoimento, no dia marcado não havia ninguém em casa e quando procurada novamente fomos informadas por sua mãe de que a mesma havia saído para ver um emprego e como havia voltado para o seu marido não gostaria de falar mais sobre o assunto. Estavam vivendo na casa de sua mãe junto com sua irmã e uma sobrinha, em uma casa de seis cômodos ainda por acabar. Não estudava e não trabalhava, mas estava procurando emprego. Durante o depoimento, ela chorou por diversas vezes quando relembrava a relação vivida com seu parceiro.

\subsection{CONHECENDO AS MULHERES ESTUDADAS}

Cada mulher, estudada nesta investigação, tem sua história, que foi construída dentro do contexto sociocultural em que foi criada. Desta forma suas histórias nos proporcionam uma visão de como este contexto de vida influenciou suas trajetórias de vida e como a maternidade na adolescência foi influenciada por ele. 


\subsubsection{CONTEXTO SOCIAL}

\section{Família de origem}

A formação de uma família se inicia pela união das pessoas que querem viver juntas, esta pode ser formalmente ou não (ALTHOFF, 2002). A Constituição Federal Brasileira de 1988 no parágrafo $3^{\circ}$ do art. 226 legitima que "para efeito da proteção de Estado, é reconhecida a união estável entre o homem e a mulher como entidade familiar, devendo a lei facilitar sua conversão em casamento" (BRASIL, 2005a, p.237).

A família, como grupo social, é uma unidade complexa e essencial para o processo de viver de todo ser humano" e se concretiza por meio da convivência (ALTHOFF, 2002, p.27). Ela cuida de seus membros, assim como socializa as crianças, atende às suas necessidades básicas e auxilia na formação dos referenciais de vida que lhe possibilitará enfrentar o mundo em permanente mudança" (MARCON, 2002, p. 45).

A família tem um importante papel na evolução do adolescente, pois é no seio familiar que ele irá vivenciar experiências de afeto, prazer, dor, medo, como também outras emoções que favorecem os aprendizados. As trocas existentes na família irão implicar em mudanças importantes na vivência dos adolescentes, na percepção e construção que ele faz de seus aspectos socioafetivos e projetos de vida (WAGNER; FALCKE; MEZA, 1997).

Amazonas et al. (2003) consideram que a família é a principal doadora de identidade e é responsável pela produção de comportamentos, sendo no seio da mesma que se concentram as possibilidades de constituição de pessoas enquanto sujeitos e cidadãos, onde irão acontecer as primeiras identificações, que serão o reflexo para as identificações futuras.

$\mathrm{Na}$ atualidade, as modificações socioeconômicas e culturais alteraram os vínculos familiares. Os membros das famílias assumem novos papéis e posições e são levados a conviver com novos arranjos familiares. "Os papéis destinados a cada sexo, antes fortemente delimitados, hoje se encontram mais flexibilizados" (AMAZONAS et al., 2003, p.11). De acordo com os autores, acima citados, na família tradicional atribuía-se ao pai a função de prover o sustento da família e à mãe a responsabilidade pelos cuidados e afetos 
dedicados às crianças. Estas funções vêm sofrendo modificações, sendo as crianças entregues aos cuidados de outras pessoas ou instituições como a escola, o que aumentam as possibilidades de identificação do indivíduo.

As famílias das mulheres deste estudo constituíram-se de pessoas pobres, na sua maioria originadas do interior do estado, alguns da zona rural e provavelmente migraram para a capital em busca de melhores condições de vida, situação que podemos observar na fala de Evelin: "Minha família é humilde, pobre, antes morava tudo no interior agora estão todos por aqui. Meus pais agora moram em um barraco em Maceió. Meu pai é ambulante". Maria, também tem a mesma vivência "Eu nasci no interior em Gravatá e meus irmãos também [...] porque meu pai trabalhava na usina [...]”. Vitória apesar de não ter certeza da cidade de origem dos pais afirma que: "A minha mãe é do interior Atalaia sei lá, Taquarana, o meu pai eu não sei, eu acho que é do interior também, de Mar Vermelho". Vera relata que "Minha familia é de Bateguara e meu pai também é de lá. Ele é falecido, há muito tempo. Minha mãe não trabalha, ela recebe pensão de meu pai”.

Os pais, na maioria do grupo, estão separados e tanto o pai quanto à mãe já constituíram outras famílias, sendo nestas famílias reconstituídas que a maioria foi criada, como nos revela Leônia: "Meu pai é casado com outra mulher tem três filhos um é falecido [...] minha mãe mora com um rapaz, mas não tem filho dele, mas vive bem graças a Deus [...]”, para Taís a família é sinônimo de sofrimento, pois para ela a sua "[...] familia é um sofrimento só. Porque primeiro minha mãe ela mora lá na Chã do Pilar, mora mais o pai da minha irmã mais nova. O meu pai é separado da minha mãe [...]”. Vitória relata que "Meu pai [...] mora em São Paulo com outra mulher".

Em suas narrativas, a maioria delas refere ter sido criada com as mães, com pouca participação masculina, ou seja, do pai biológico que teve pouca participação, no processo de aprendizado no núcleo familiar. Em alguns casos, o pai já estava falecido. A separação dos pais aconteceu quando elas eram crianças ou estavam na pré-adolescência, fase fundamental na construção da identidade feminina e de importantes aprendizados.

Maria nos narra que ela se separou do pai, seu pai faleceu há quase dois anos quando ela tinha 19 anos,

“[...] não convivi com o meu pai. Porque me separei dele, tinha uns quatro anos. Ele vivia com outra mulher, minha mãe veio, ele ficou 
morando em Recife, eu não tinha contato com o meu pai, eu vim ter contato com o meu pai foi com 12 anos, eu fui pra casa dele, depois quando vim ver ele de novo, tava com 19 anos" (Maria).

"Vivia com a minha mãe, minha mãe se separou dele parece que eu tinha seis anos". Aparecida diz: "Eu só tenho mãe, meu pai morreu. Minha mãe agora é viúva, mas não casou e agora ela ta amigada. Minha mãe ela tem 49 anos é doméstica, mas ela está desempregada" (Tieta).

A separação do casal ou morte do pai transformou suas vidas, pois de acordo com suas falas eles eram os principais provedores da família, como afirma Uliane "Quando eu era pequena sempre tive de tudo graças a Deus, meus pais sempre tiveram condições de me dar tudo, a minha mãe diz a gente tinha uma vida ótima, pra hoje em dia a vida que a gente tem não tem quem diga". Para Aparecida esta mudança também aconteceu "quando meu pai era vivo a gente tinha tudo, mas quando ele morreu, o homem disse que para minha mãe ficar na fazenda a gente tinha que trabalhar”.

Em sua maioria as mulheres relatam manter um bom relacionamento com as mães, sendo o pai uma figura mais distante em suas vidas diárias. Os vínculos com as mães na maioria delas se mostram mais fortalecidos que os vínculos paternos. Vejamos os relatos abaixo sobre esta questão:

"Meu pai tá separado da minha mãe, tá com mais de ano que não o vejo. Eu tenho 23 anos, mas ela ${ }^{2}$ se preocupa muito comigo, diz que tem vontade de ajudar a mim e aos meus filhos só que não tem condições" (Caroline).

"A minha família é a melhor possível, todos gostam uns dos outros, principalmente de ajudar quando tem dificuldade ou tá passando por algum momento ruim, eles sempre ajudam. Com o meu pai eu não tenho muita afinidade como antes" (Isadora).

Observamos que este relacionamento mais perto com a mãe está de acordo com a teoria de Chodorow (1979) que afirma que o envolvimento precoce com a figura feminina implica em conseqüências distintas para o desenvolvimento de meninos e meninas,

\footnotetext{
${ }^{2}$ Fazendo referência a sua mãe.
} 
auxiliando as meninas a traçarem seu papel sexual e de gênero de uma maneira natural, sendo a construção da identidade feminina baseada na aprendizagem.

Neste ponto Uliane é uma exceção, relata não ter um bom relacionamento com a mãe, queixa-se da falta de diálogo e de afeto por parte dela, apesar de viverem fisicamente próximas, porém refere um bom relacionamento com o pai apesar do pouco contato que mantém com ele, devido ao trabalho que o mesmo desenvolve. "Eu falo mais com ele pelo telefone, mas se vê mesmo só de ano em ano. Ele mora mais ou menos perto, mas pra se vê é um problema. Eu nunca tive um bom entendimento com a minha mãe”.

As mudanças estruturais das famílias destas mulheres, ocorridas quando elas eram crianças ou adolescentes pela separação dos pais ou morte do pai, levaram-nas a viver processos de reconstituição familiar de um deles ou de ambos e podem influenciar em seus próprios relacionamentos e nas escolhas que fariam para o seu futuro. $\mathrm{O}$ contexto socioeconômico e cultural da família, também, pode ter influenciado diretamente no processo de formação destas mulheres.

Observamos que nestas famílias encontramos a feminilização da pobreza, pois a perda do provedor, seja por morte ou separação, as levaram a mudanças nas condições de vida que tinham. As mulheres que pela sua condição de mulher cuidavam dos filhos, agora também teriam de provê-los, foram as mulheres que ficaram com os filhos quando da separação, tornando-se chefe da família, evidenciando que com a desestruturação familiar, as mulheres são colocadas em desvantagem social. Mesmo sabendo que a situação da mulher melhorou nos últimos anos, a pobreza em nosso grupo de mulheres agrava a situação de desigualdade em que vivem.

\section{Escolaridade}

A Educação Infantil e o Ensino Fundamental são duas etapas extremamente importantes para o desenvolvimento integral do ser humano. Os estímulos que uma criança recebe nos primeiros anos de vida definem seu sucesso escolar e seu desenvolvimento (BRASIL, 2005b). O Departamento de Políticas de Educação Infantil e Ensino Fundamental do MEC analisa que a gestão democrática da escola, os materiais didáticopedagógicos e a formação do professor são fatores determinantes para a qualidade social 
da educação que forma indivíduos críticos e criativos, preparados para o pleno exercício da cidadania (BRASIL, 2005b).

O Ensino Fundamental é composto por oito anos de estudo, sendo a idade fixada para o ingresso da criança de sete anos e sua conclusão esperada para a idade de 14 anos.

A idade de ingresso das mulheres estudadas no Ensino Fundamental foi variável. As questões familiares e sociais que interferiram no ingresso e continuidade na escola são narradas por Leônia "Quando eu comecei a estudar mesmo eu tinha 9 anos, porque minha mãe vivia saindo de um lugar para outro, ai tinha que deixar a escola". Evelin é analfabeta entrou na escola com nove anos, também, com dois anos de atraso e teve dificuldade de se manter estudando, pois segundo seu relato, às vezes, ia para a escola com fome, fato que por si só dificultou o seu aprendizado e pode ter contribuído para seu fracasso escolar. Vejamos o que Evelin nos contou:

"Minha mãe me colocou na escola com nove anos, eu e meu outro irmão. Estudei mais de um ano. Também nunca aprendi nada, que eu ia chegava lá na escola só pra bagunçar, dava pra brincar. [...] Ela ajeitava a comida, eu não sabia fazer comida, mas eu às vezes saía de casa com fome, ela chegava nas carreiras, eu tomava banho, só fazia trocar de roupa e ir pra escola com fome. Quando me ajeitava para pra ir para a escola, só chegava tarde. Aí eu disse não dá não, ou estudar ou ficar logo dentro de casa, mas assim não dá não. [...] Aí foi quando eu já tava com meus 14 , dentro de casa aí eu disse: - vou estudar mais nada, quero estudar não" (Evelin).

As mulheres apresentam de uma maneira geral uma baixa escolaridade, e por meio dessas narrativas é possível observar um atraso na progressão normal durante sua freqüência à escola. Apenas uma concluiu o Ensino Fundamental, três delas não concluíram a $4^{\mathrm{a}}$. série do Ensino Fundamental e duas apesar de terem freqüentado a escola eram analfabetas. Tal fato aponta o fracasso escolar que elas tiveram e pode ter sido reflexo de um rendimento insatisfatório, conforme podemos ler nos trechos a seguir:

"[...] fazia a $5^{\text {a }}$. série, mas tinha o temperamento rebelde demais, aí não dava certo que eu não me aplicava muito nos estudos". (Orquídea). 
"Comecei estudar pequena nunca me interessei não. Estudei a $2^{\mathrm{a}}$ série e parei, eu não gosto muito de estudo, agora eu começo, me dá uma preguiça, aí pronto vem as provas e eu não vou [...]” (Maria).

"Estudar pra mim era um saco, nunca gostei de estudar. Acho que comecei a estudar com sete anos. Fiz até a $5^{\text {a }}[\ldots]$ eu nunca fui muito afim de escola, nunca tive paciência pra estudar" (Uliane).

Observamos em suas falas que elas atribuem o seu fracasso escolar a si próprias pelo desinteresse pelos estudos, não questionando a qualidade da escola ou dos professores, fatores que podem ter contribuído para o desinteresse pelos estudos apresentados por elas.

Outras razões citadas por elas que dificultaram a manutenção na escola ou seguimento na sua progressão escolar regular incluem questões sociais e familiares como: o difícil acesso à escola, a desagregação familiar, o trabalho infantil e a desestruturação da rede estadual de ensino identificada por meio das greves dos professores ocorridas durante o período em que elas freqüentavam a escola.

“[...] A pessoa que já não gosta e você vê tanta dificuldade pra estudar, tanta greve, aí você só espera um pezinho pra sair. Quando começou a greve, eu saí e não voltei mais" (Uliane).

Com Taís e Aparecida foi o trabalho infantil que as tirou da escola, como veremos nos relatos abaixo:

"Ela nos botou na escola pública quando a gente era pequena, mas quando a gente tava na primeira série ela já tirou para trabalhar [...] eu nem estudei, não sei ler eu mal sei fazer o meu nome, às vezes o meu marido me ensina a fazer, tá entendendo? Ele faz pra eu ir fazendo. Eu agora não tenho paciência mais de estudar, vontade eu tenho, mas paciência não tenho um pingo" (Taís).

"Desde pequena eu estudo [...] a gente sempre ia pra escola, só que estudava em escola de fazenda que não tinha registro, estudar era o mesmo que nada, mas acho que não terminei o ano porque quando 
ele morreu, eu tive que trabalhar pra ajudar minha mãe" (Aparecida).

Leônia estava fora da progressão regular, mas freqüentou a escola até a separação dos seus pais, e nos fala,

"Eu fiz só até a $4^{\text {a }}$, parei porque o meu pai quando separou da minha mãe, a gente tava muito pequena, aí eu vivia andando de um canto pro outro e ficava mudando de casa, fui pro interior aí começou a atrasar meus estudos e eu deixei de estudar por causa disso. Deixei de estudar na 5 a série, tava com 13 anos". (Leônia)

Vitória era a única que vinha numa progressão regular, quando as condições familiares e a greve dos professores não lhe permitiram continuar:

"Eu acho que eu comecei ir pra escola tinha três anos $[\ldots]$ no ano que eu ia fazer sete anos comecei a fazer a $1^{\text {a }}$ série aí eu fiz a $1^{\mathrm{a}}$, a $2^{\mathrm{a}}$, a $3^{\mathrm{a}}, 4^{\mathrm{a}}, 5^{\mathrm{a}}, 6^{\mathrm{a}}$ aí quando cheguei a sétima eu tava com 13 anos aí teve uma greve, a greve durou seis meses [...] eu fiz a sétima série terminei no outro ano e comecei a atrasar. [...] nesse tempo eu tava na casa da minha irmã [...] Quando no começo do ano eu vim pra casa e minha irmã foi no meu lugar aí eu não estudei porque não tinha como pagar a passagem do ônibus. Minha mãe não podia pagar, e eu já tava assim com 14 anos e não tinha como tá passando por debaixo da roleta ou entrando pela frente no ônibus, aí eu fiquei sem estudar um ano. Aí no finalzinho do ano eu voltei pra lá e eu voltei a estudar, fiz a oitava série, já tava com 15 anos [...]". (Vitória)

A deteriorização do ensino público, no Brasil, vem ocorrendo há muito tempo e no período de transição do regime autoritário para o estado de direito a sociedade assistiu ao desmando da escola, configurando-se com um caráter excludente. Nela, a população desfavorecida economicamente está sujeita a um ensino de qualidade questionável e pouco atrativo o que nos mostra uma contradição, visto que a escola deveria ser o local em que este grupo teria suporte e adquiriria os elementos essenciais para a construção de sua cidadania. 
Quem não conseguiu se manter na progressão regular apresenta outras dificuldades para continuar os estudos, pois nesta comunidade tem apenas uma escola pública estadual com quatro salas de aula, onde funciona da $1^{\text {a }}$ a $4^{\text {a }}$ série do Ensino Fundamental. Assim apesar do interesse da maioria destas mulheres em continuar os estudos, existem dificuldades locais como a não existência de ensino para adultos, que constitui outro obstáculo para se manter na escola em decorrência da necessidade de deslocamento para locais distantes dos seus domicílios.

Verificamos que a escola não foi prioridade para essas mulheres ou para suas famílias quando de sua infância. As famílias tiveram dificuldades em criar condições adequadas que mantivessem o interesse de seus filhos pela escola, acompanhando a progressão escolar esperada e, além disso, por uma questão de sobrevivência, muitas vezes, se viu obrigada a usar a força de trabalho infantil para sua subsistência. Isso ocorreu, em alguns casos devido à perda do provedor, seja por morte ou separação e fez com que a escola ficasse em segundo plano. Dessa forma, criou-se um ciclo de vida em que as necessidades de sobrevivência as impediram de se manter na escola ou de conseguirem uma progressão regular nos estudos que lhes desse subsídio para escolhas futuras fora do contexto doméstico, favorecendo que elas tivessem mais perspectivas quanto a este futuro.

As histórias de vida das mulheres pesquisadas apontam para o fato de que nove delas, quando engravidaram, estavam estudando em séries aquém do esperado para a sua idade, demonstrando haver uma inadequação entre a idade e a série contribuindo para que com essa ocorrência elas tomassem a iniciativa do abandono da escola.

Entre as razões apontadas para o abandono da escola, destacamos algumas ligadas à própria gravidez como: vergonha de estar grávida, necessidade de cuidar do filho e mudanças de local de moradia. Vale ressaltar que nenhuma delas se ressentiu de comportamentos preconceituosos por parte de professores ou colegas de classe como motivo para deixarem a escola, o que pode significar que as mesmas não se sentiam diferenciadas ou constrangidas pela escola por estarem grávidas:

"Na época que eu engravidei eu só tava estudando eu não tava mais trabalhando. Eu deixei de estudar quando tava já com uns seis meses de gravidez, que quando eu ia logo no começo da gravidez pra escola aqueles enjôos e aquelas agonias, quase sempre eu 
passava mal, aí eu mais nunca quis ir pra escola, aí eu parei de ir até hoje" (Uliane).

Leônia e Vitória vivenciaram situações parecidas e ambas gostavam de estudar. A primeira relata:

"Eu achava boa a escola porque o meu sonho era terminar o meu estudo e fazer enfermagem que eu sempre achei bom. Eu mesmo queria fazer parteira, $[\ldots]$ o meu sonho era terminar meus estudos e me formar em alguma coisa. Mais felizmente não pude. Não pude porque eu fui logo engravidar, que eu podia estar namorando e estar com meus estudos, mas a cabeça foi mais de adolescente e não me preveni e engravidei logo [...]" (Leônia).

"[...] no outro ano comecei a fazer o primeiro ano e não terminei, acho que tava no quarto bimestre já. Foi quando eu engravidei do Jonathan que teve a greve aí eu não fui mais pra escola, fui até cinco meses sabe? Quando voltou, eu já tinha ele novinho [...]" (Vitória).

Mariana assim relata:

"Eu não concluí a $8^{\mathrm{a}}$ série. [...] ficou faltando três provas [...] Porque quando eu fui morar com ele, fui morar em Ipioca, e lá o colégio era muito distante não podia estudar, trabalhar também não podia porque ele não deixava, [...] tive que parar de estudar. Quando eu tive a Vanessa foi que eu não pude estudar mesmo, pois ela era pequena, aí fui cuidar dela" (Mariana).

O caso de Aparecida reflete uma outra situação que pode ser vivida no contexto da escola, por algumas jovens que engravidam. Ela relata que tinha vergonha de estar grávida e não ter tido esta gravidez assumida, de imediato, pelo parceiro e que devido a isso, acreditava não ser aceita pela sua condição de mãe solteira. "Da Bárbara eu estudava, estava na $6^{a}$. série. Ai desisti com vergonha do povo falar [...] Já da gravidez da Raí eu estudei um ano porque eu com marido, não é? Não tinha vergonha”.

Ao que parece a gravidez, sem assunção do companheiro, entre as mulheres entrevistadas colocaram-nas em situação de constrangimento no seu núcleo social. As 
outras mulheres não referiram vergonha de sua barriga, mas ela teve medo da censura crítica de suas colegas, refletindo as concepções socioculturais da gravidez na adolescência que é aceita, desde que esta seja resultado de uma relação afetiva e assumida pelo parceiro.

Pantoja (2003) em um estudo acerca da gravidez/maternidade na adolescência, com um grupo de jovens de camadas populares de Belém do Pará, também encontrou um alto índice de repetência e níveis de inadequação série/idade, mas apesar da repetência compor esse cenário, não levou, necessariamente ao abandono da escola. Para a autora ao contrário, "pode ser um tipo de estratégia utilizada por muitos alunos para nela permanecerem por um período mais prolongado e manter as redes de sociabilidades construídas nesse ambiente" (p. S340).

No referido estudo, a permanência na escola ou a continuidade dos estudos mantiveram uma correlação com outros fatores e a maioria das entrevistadas destacou os projetos profissionais, pensados em termos de mobilidade social futura, como o desejo de entrar na faculdade e assim obter uma profissão e inserção no mercado de trabalho em condições mais favoráveis, como contributivos para a sua permanência no sistema formal de educação, fato que não ocorreu entre as mulheres do nosso estudo.

Lima; Kobata e Silvestrini (2000), em sua pesquisa, constataram a existência de uma baixa escolaridade entre as jovens, como também o abandono dos estudos nas séries iniciais do primeiro grau, ou seja, do Ensino Fundamental, assim como verificaram que elas não se ocupavam de suas formações intelectuais e profissionais. Esses dados corroboram com nossos achados, porém de acordo com os autores a grande maioria das gestantes pesquisadas não estava estudando quando engravidaram, ao contrário de nossas depoentes que das 14 entrevistadas nove estavam na escola quando engravidaram. Como vemos na fala de Esmeralda:

"Quando eu fiquei grávida eu tava estudando. Eu parei de estudar depois que eu completei cinco meses porque era longe [...] Voltei, estudei mais um ano ou dois anos, aí eu fiquei grávida de novo e parei de novo de estudar, pronto não estudei mais. Estudei até a $2^{\text {a }}$ série, mas antes tive que repetir o ano, sabe? Aí estudei até a $2^{\text {a }}$ série, depois fiquei grávida pela terceira vez, eu tinha uns 18 anos, e assim fui vivendo.Quando eu tava com uns 19 anos, eu comecei 
de novo a estudar. Eu tava cursando a $3^{\text {a }}$ série e a $4^{\text {a }}$ série, agora esse ano que passou" (Esmeralda).

As mulheres, quando narram o abandono escolar, demonstram arrependimento por não terem se dedicado mais aos estudos e relacionam a situação atual de suas vidas com a falta de qualificação o que lhes impede de ter melhores possibilidades de trabalho e conseqüentemente mobilidade social. Entretanto, apesar do fracasso escolar que elas vivenciaram em suas trajetórias de vida, a gravidez ser a principal razão da evasão escolar e a maternidade o ponto de dificuldade na continuidade dos estudos, observa-se que ser mãe entre elas pode ser considerado como sucesso de um projeto de vida, em algum momento, estabelecido por ela.

Orquídea acredita que lhe faltou juízo por ter engravidado cedo e caso isso não tivesse ocorrido poderia ter continuado a estudar e hoje estaria trabalhando, ou seja, com outra perspectiva de vida. Ela sente-se presa dentro do contexto da maternidade, fato que lhe impossibilita outras realizações pessoais: "Faltou juízo, se eu tivesse mais juízo antes de ter tido esta criança, se tivesse mais cuidado, se eu tivesse pegado nos estudos, eu tava livre. É se eu tivesse meus estudos mesmo eu tava com meu trabalho, trabalhando em farmácia, menos em casa de família que eu não gosto”.

Maria e Tieta revelaram que quando tinham apenas uma filha tiveram condições de continuar a estudar, no caso de Maria sua mãe ficava com a neta, entretanto agora que ambas têm uma segunda filha não vêem perspectiva para continuar os estudos, provavelmente devido a não existir uma rede de apoio com a qual possam contar para o cuidado das filhas enquanto freqüentam as aulas, uma vez que a família, às vezes, não tem condições ou não quer assumir esta responsabilidade. Os aparelhos sociais como creche e pré-escolas com as quais as mães deveriam contar para deixar os filhos por algumas horas são escassos, o que faz aumentar as dificuldades para o retorno à escola e colaborar para que elas se mantenham num imobilismo que as mantém, não fazendo outra coisa que não seja cuidar das filhas (os).

"To fazendo a $3^{\text {a }}$ agora, voltei ano passado, ta com um ano que eu voltei a estudar. Ah! Depois de grande achava bom, estudar. Minha mãe ficava com a Joyce e eu ia estudar quando tava grávida dela. Aí depois que a Letícia nasceu eu parei. [...] eu voltei a estudar de 
novo, que a minha mãe ficou. Agora vai ser duas [...] não sei agora como ela vai ficar, pra eu voltar a estudar de novo" (Maria).

"Da Bruna eu parei de estudar, e da Adriele também parei, da Bruna eu tava parece que era na sexta. Quando ela completou um ano eu continuei, passei pra sétima série, aí passei, quando da Adriele eu já estava na oitava série. Aí eu desisti que a gente tinha se separado. Aí depois voltamos e fui morar com ele no Clima Bom. Agora eu não estou estudando, por causa da minha segunda filha que eu engravidei de novo e parei de estudar, porque eu fui morar na casa do meu sogro e ficava muito longe da escola [...]" (Tieta).

É importante, entretanto, que não reduzamos o abandono escolar dessas mulheres somente ao fato de terem engravidado ou de serem mães, mas o fracasso e o abandono escolar provocado pela gravidez podem estar relacionados com o contexto de desvantagem social em que elas estão inseridas, como também à falta de um apoio, para que elas pudessem continuar a estudar, pois como já pudemos observar, o fracasso escolar já era uma realidade antes da ocorrência da primeira gravidez.

\section{Trabalho antes da gravidez}

O trabalho infantil tem sido discutido, em nível mundial, como uma exploração a ser combatida pelos governos. O Brasil vem ratificando as recomendações de diversas Convenções Internacionais da Organização Internacional do Trabalho - OIT, sobre o trabalho infantil e conexos, desde 1965, tais como: Convenção 138-OIT "Sobre a Idade Mínima de Admissão ao Emprego" que foi aprovada na $58^{\mathrm{a}}$ reunião da Conferência Internacional do Trabalho em Genebra em 1973 e entrou em vigor no plano internacional em 19/6/76, sendo ratificada pelo Brasil apenas em 28.06.01; Convenção 182-OIT "Piores Formas de Trabalho Infantil", ratificada em 02/02/00; Convenção das Nações Unidas sobre os Direitos da Criança, ratificada em 1999; Convenção 100-OIT "Sobre igualdade da remuneração", ratificado em 1957; Convenção 105-OIT "Sobre a abolição do trabalho 
forçado", ratificada em 1965; Convenção 111-OIT "Sobre a eliminação da discriminação na ocupação e no emprego", ratificado em 1968; Convenção "Sobre a eliminação de todas as formas de discriminação contra a mulher", ratificado em 1979; Convenção "Sobre a eliminação da discriminação racial”, ratificada em 1965 (OIT, 2004; ANDI, 2004).

O cenário do trabalho de crianças é revelador de uma diversidade impressionante de situações em que se obriga ou se permite a inserção ilegal de pessoas com menos de 16 anos em atividades de natureza não educacional, decorrência da exploração barata, do abandono ou da negligência. Nesse quadro, tem-se constatado em todas as regiões do país, principalmente na zona rural, impressionante contingente de crianças envolvidas no trabalho doméstico, na plantação e colheita da cana-de-açúcar, do fumo, do algodão, do sisal e de frutas; nas atividades da indústria cerâmica, nas pedreiras, nas casas de farinha, nas carvoarias e na fabricação de cal (caieiras), dentre muitas outras. (NETO, 2000).

Traverso-Yepez e Pinheiro (2002) apontam que, em razão da falta de oportunidades de educação, trabalho, lazer e cultura, decorrentes das grandes desigualdades estruturais vigentes, a única coisa garantida é a reprodução, em maior ou menor grau, do círculo vicioso de pobreza na qual essas crianças e adolescentes estão inseridas. As autoras questionam a "limitação das ações que objetivam apenas garantir a sobrevivência das crianças, sem a preocupação de garantir-lhes possibilidades de uma vida digna" (p.139).

Encontramos no grupo estudado, o trabalho infantil como parte de sua realidade, com predomínio do trabalho doméstico. $\mathrm{O}$ trabalho infantil doméstico caracteriza-se pelo trabalho de crianças e adolescentes, menores de 16 anos, realizado no domicílio de terceiros, remunerado ou não, consistente, em geral, em fazer faxina na casa, lavar, passar, cozinhar e cuidar dos filhos dos donos da casa (ANDI, 2004). No Brasil, o trabalho para menores de 16 anos é proibido, exceto na condição de aprendiz na faixa etária dos 14 aos 16 anos, o que não é o caso do trabalho doméstico, pois o mesmo não é uma atividade geradora de qualificação profissional para a inserção no mercado formal de trabalho.

O fato de estas meninas trabalharem dentro do domicílio de terceiros as torna mais vulneráveis a outros tipos de exploração, inclusive a sexual, como aconteceu com Evelin que nos relatou o seguinte fato:

"[...] minha mãe $[\ldots]$ me pediu pra eu ir com ela, $[\ldots]$ me deixou com o menininho. Esse homem aí, quando chegou que veio olhar 
perguntou logo como ele tava eu disse que tinha ido para o hospital, aí ele disse: - só eu e esta essa menina aí; [...] me puxou pra o quarto e eu disse, - por que você está fazendo isso, aí ele disse - cale a boca, se você gritar aí você morre”. (Evelin)

No caso de Taís e Aparecida, este trabalho começou na infância com o trabalho na zona rural depois da morte do pai e mostra a exploração por que elas passaram. Os fatores que as levaram a se inserirem no mercado de trabalho infantil foram gerados pela perda do pai, que era provedor da família; pela necessidade financeira da família ou pelo desejo de se tornar independente da família. Esta inserção precoce no mercado de trabalho pode ser considerado um ensaio em busca de autonomia destas meninas e um aprendizado em assumir responsabilidades no contexto da realidade do trabalho.

“[...] eu comecei a trabalhar pequeníssima, porque a gente morava no interior, num sítio. Minha mãe criava a gente eu e meu irmão, porque os outros viviam com a minha vó, [...]. Limpava a roça, cortava os mato, e às vezes eu ia pra cana mais meu irmão cortar, era um sofrimento que a senhora nem sabe, limpando cana, botando adubo" e depois "a minha mãe me botou pra trabalhar na casa dos outros [...] sozinha, num sabia o que era quando cheguei aqui que eu diga: "êita" meu Deu onde é que eu tô, que a cidade era tão grande, eu nunca tinha vindo, a primeira vez que eu vim quase endoidei, foi. Eu tinha onze, quase doze. Quando eu vim, fiquei lá, a mulher nem pagava, me dava era roupa daqueles retalhos de pano velho, que ela comprava e fazia aquelas roupas horrorosas e me dava para vestir, de três em três meses é que ela ia lá e dava cinqüenta conto a minha mãe. Eu nem sabia, num era nem cem reais ainda era aqueles outros dinheiro lá" (Taís).

Aparecida iniciou trabalhando na cana-de-açúcar e depois passou para o trabalho doméstico, o qual afirma ter sido bom pelo aprendizado que teve no cuidado doméstico:

"Eu comecei a trabalhar com uma base de uns nove anos, que a gente morava numa fazenda, [...], minha mãe olhou assim pra gente com muita dó, mas a gente teve que trabalhar, toda hora, cortando cana, limpando cana. [...] Trabalhei como doméstica, aí tinha 
comida na hora certa. Tem patroa que não é ruim que cuida da pessoa, que não é ignorante, mas tem patroa que é ruim demais, mas foi melhor para mim, melhor que aprendi um bocado de coisa, tem pessoa que diz que trabalhar de doméstica é ruim, não, se pega uma patroa que goste de ensinar, aprende muita coisa" (Aparecida).

Observamos que o trabalho fez parte da realidade de vida da maioria das mulheres de nosso estudo e o mesmo foi necessário frente às condições de vida das mesmas e à falta de suporte social a que são submetidas muitas famílias economicamente desfavorecidas. A inserção em atividades laborais precocemente faz com que as pessoas envolvidas sejam afastadas da escola ou acabem tendo uma freqüência irregular o que prejudica sua progressão escolar.

"Com 13 anos trabalhei de babá quando morava com minha mãe e já trabalhei em casa de família também, era um casal e eu ficava mais em casa com o filho dela, eu era adolescente com quatorze anos, eu era muito nova então [...]" (Orquídea).

Observamos que apesar das razões presentes nas falas para a inserção precoce no mercado de trabalho, estas estão diretamente relacionadas com a miséria e a pobreza em que elas estão inseridas e que são responsáveis pela exclusão social detectada neste grupo, característica da realidade dos países subdesenvolvidos e em desenvolvimento. Para Evelin, o trabalho doméstico a trouxe para a capital,

“Eu vim pra cá pra trabalhar, meu tio foi pra lá onde eu morava, os pais dele moravam lá, irmão da minha mãe, chegou lá e disse: você não quer trabalhar na casa de família, - quero; era uma oportunidade pra trabalhar. Vim para cá, comecei a trabalhar, ele me colocou numa casa de uma conhecida dele" (Evelin).

Segundo a Agência de Notícias dos Direitos da Infância - ANDI (2004), as mulheres inseridas nos trabalhos domésticos infantis, por não terem tido a chance de estudar durante o período da infância e da adolescência, dificilmente têm chance de conseguir uma requalificação profissional quando se tornam adultas, fato que constatamos entre as depoentes. 
Na convenção 138 -OIT em seu art. $3^{\circ}$, parágrafo $1^{\circ}$ está definido que a idade mínima para admissão não será inferior a dezoito anos em qualquer tipo de emprego ou trabalho que, por sua natureza ou circunstâncias em que for executado, possa prejudicar a saúde, a segurança e a moral do jovem (ANDI, 2004).

A Constituição da República Federativa do Brasil, de 1988 (BRASIL, 2005), na composição do artigo 227 do capítulo VII sobre a família, a criança, o adolescente e o idoso, descreve a proteção da criança com o seguinte texto:

É dever da família, da sociedade e do Estado assegurar à criança e ao adolescente, com absoluta prioridade, o direito à vida, à saúde, à alimentação, à educação, ao lazer, à profissionalização, à cultura, à dignidade, ao respeito, à liberdade e à convivência familiar e comunitária, além de colocá-los a salvo de toda forma de negligência, discriminação, exploração, violência, crueldade e opressão (BRASIL, 2005, p. 238).

Apesar do que está previsto na Constituição Brasileira, a maioria das mulheres depoentes em nossa pesquisa não teve seus direitos atendidos. Elas foram inseridas precocemente no mercado informal de trabalho e em sua maioria realizou trabalho doméstico remunerado ou não. O desenvolvimento destas atividades com o cuidado de casa e de criança, entre outras coisas, tem sido considerado como atividades femininas e, na maioria, tem sido compreendido como um bem para as mesmas meninas, preparanodoas para assumirem suas próprias famílias posteriormente. Entretanto, mais recentemente, esses trabalhos têm sido analisados como uma das formas de exploração do trabalho infantil, fazendo com que a infância e a pré-adolescência destas jovens sejam vividas de maneira distinta de outras jovens, pois esta inserção precoce no mercado de trabalho gera sentimentos de exploração como relatado por Orquídea: "assim eu tomava conta de tudo, eu ganhava muito pouco, ela me explorava”.

Em um programa sobre o Trabalho Infantil da MTV, encontramos a seguinte declaração sobre o trabalho doméstico:

As meninas vão morar na casa onde trabalham, são acolhidas pela família como uma "filha" adotiva, mas vivem um regime de semiescravidão. Trabalham sem carteira assinada, em longas jornadas e sem folgas, até nos fins de semana. Um estudo do Instituto de Pesquisa Econômica Aplicada (IPEA) revelou que 23\% das crianças de 10 a 14 anos, empregadas no trabalho doméstico desempenham jornadas acima de 48 horas semanais. O número sobe para $30 \%$ na faixa de 15 a 17 anos. Além disso, percebem remuneração baixíssima, e algumas nem têm salário, pois seus patrões acham que oferecer casa e comida já é o suficiente (MTV, s/d). 
Esta situação é observada em Alagoas, onde, freqüentemente, famílias com melhores condições econômicas, sejam no interior do estado ou da capital, levam crianças de famílias pobres, geralmente da zona rural, para morarem em suas casas com o objetivo de lhes darem oportunidades de "estudar" e em troca elas lhes ajudam a cuidarem dos filhos e colaboram nas tarefas domésticas num regime de disponibilidade ilimitada, como descrito acima, com agravamento de que muitas vezes não são remuneradas. Devido a elas terem a responsabilidade de realizar tarefas domésticas, as mulheres são matriculadas na escola noturna, com prejuízo para o seu aprendizado, como declarado por Vitória: "Eu estudava, de noite e de dia eu ficava na casa da minha irmã durante o dia eu ajudava ela lá, tomava conta do meu sobrinho".

Estas meninas que moram na casa dos "protetores/patrões" podem não ter um bom desempenho e sucesso escolar seja porque estão cansadas demais no final do dia, seja porque têm de trabalhar também durante a noite ou porque não têm tempo de se dedicarem às tarefas escolares como deveriam, podendo ser, este, um dos fatores que colaboram para a baixa escolaridade encontrada no grupo. Este trabalho as coloca prematuramente no mundo dos adultos, assumindo responsabilidades e tendo vivências também adultas, tirando uma parte importante de seu processo de formação no mundo infantil e lúdico, influenciando seus projetos de vida, pois sua preparação, orientação e experiências de vida estão mais voltadas para o mundo doméstico.

Como todos os fatos da vida estão inter-relacionados, podemos supor que o baixo rendimento escolar, encontrado entre as mulheres participantes desta pesquisa, pode estar relacionado com sua condição econômica e falta de oportunidade que as obrigam a se inserirem precocemente no mercado informal de trabalho infantil.

\subsubsection{SEXUALIDADE E REPRODUÇÃO}

\section{Namoro e primeira relação sexual}

Loyola (1998) afirma que sexualidade é um dos pilares de nossa sociedade cujas normas não são homogêneas, variando de uma para outra com relação ao que se é permitido e ao que se é proibido fazer. Em relação à moral da sexualidade, pode-se definir como um conjunto de valores e de regras de ações propostas, geralmente, pela igreja, 
instituições educativas, entre outros, aos indivíduos e aos grupos. Entende-se que o “comportamento real dos indivíduos em relação às regras e valores que lhes são propostos: designa-se assim, a maneira pela qual eles se submetem [...]" (FOUCAULT, 2001a, p. 26) a um princípio de conduta que os indivíduos podem aceitar ou podem resistir a elas.

Para Bonzon (1998), as normas, as representações e os comportamentos masculinos e femininos na área da sexualidade podem ser vistos numa perspectiva de gênero, sendo constitutivos de uma socialização ativa que expressa uma das maneiras fundamentais da dominação social masculina.

Salem (2004, p. 18), analisando dados qualitativos de um estudo multicêntrico, realizado em 2000, sobre gravidez na adolescência entre homens de classe popular constatou que eles foram quase unânimes em afirmar "que os gêneros estão submetidos a regimes sexuais diferentes", sendo os mesmos impulsionados ao sexo pela "vontade", em contraposição ao discurso feminino que aparece como "curiosidade". Curiosidade também é o que encontramos no relato de Caroline, assim como o seu desconhecimento do que era um ato sexual entre um homem e uma mulher, sua motivação pode estar relacionada com a pressão exercida pelo seu grupo social:

"Só que não sabia o que acontecia, quer dizer assim porque a minha colega mais velha que eu, sempre falava e eu comecei a descobrir como era, ter a experiência de saber como era, que tinha a curiosidade de saber como era" (Caroline).

Observamos que, pelo fato de nossas depoentes terem baixa escolaridade, dificuldade de acesso aos serviços de saúde, antes que o PSF se instalasse na comunidade, e dificuldade de diálogo dentro do contexto familiar, as mesmas não tiveram oportunidade de se inserirem em programas de orientação sexual que lhes auxiliassem a compreender e a aprender acerca da sua sexualidade, situação que as deixaram mais vulneráveis aos riscos pertinentes ao exercício da mesma, pois de acordo com Bozon (2004, p. 40) "a adolescência é uma idade que tem como objetivo o acesso à sexualidade".

A experiência com o namoro neste grupo de mulheres se iniciou em idade precoce, Uliane começou a namorar com 11 anos, ele tinha aproximadamente 15 anos, com este namorado teve sua primeira experiência sexual, com aproximadamente dois anos de namoro, 
"Quando eu comecei a namorar tinha uns 12, ia fazer 12 anos, comecei a namorar cedo. [...] Acho que com uns dois anos de namoro a gente teve a primeira relação" (Uliane).

A precocidade na iniciação sexual é discutida por Foucault (2001b) que afirma que as crianças podem estar predispostas a terem atividade sexual, o que pela sociedade atual não é aceita, pelos riscos que envolvem seu exercício sendo alvo de vigilância e controle. Observamos por meio das histórias das mulheres pesquisadas que as famílias exerciam um controle muito frágil sobre a sexualidade dessas adolescentes, o que facilitou o contato com o sexo oposto com quem estabeleceram relações afetivas e sexuais longe do controle familiar. Vejamos o que algumas delas nos falaram a esse respeito:

"Minha primeira relação foi com 14 anos com um namorado que eu tinha. Ele tinha uns 15, 16 anos a diferença era pouca. Eu já escutava minhas amigas, que já tinha relações [...]” (Maria).

"Eu tinha 15 anos quando arranjei meu primeiro namorado. E minha primeira vez foi que assim, êita meu Deus que coisa complicada. [...] eu tava já completando os 16 , foi desse mesmo namorado, sabe? Eu acho que ele tinha 26 ou era 25. Eu tava namorando, assim como não quer querendo, aconteceu e no outro dia ele foi embora pra São Paulo, e eu fiquei sozinha. A gente não usou preservativo nem nada, mas eu não engravidei não, da primeira vez não [...]" (Taís).

"Eu comecei a namorar ele com 13 anos, eu tenho 20 anos agora e vai fazer sete anos que a gente de tudo tá junto. Eu já ia completar 16 anos quando eu tive a minha primeira relação. Eu não sei assim explicar bem o que é que eu sabia, eu sei que aconteceu" (Tieta).

Das depoentes, oito iniciaram sua vida sexual entre os 15 e 16 anos, as outras entre 13 e 14 anos. A iniciação sexual neste grupo aconteceu com o namorado, sendo a maioria o primeiro namorado e, no caso de oito delas este, mais tarde, se tornaria seu companheiro, pai de seus filhos. Apenas uma delas não nos falou sobre a idade em que iniciou sua atividade sexual. 
A passagem para a sexualidade genital, neste grupo, parece estar ligada aos vínculos afetivos formados com estes namorados, apesar de não podermos demarcar este vínculo com o tempo de relação que os casais tinham antes da primeira relação sexual, pois variam de meses a anos de relacionamento. Assim a iniciação sexual deve ter acontecido dentro de um processo de descoberta do corpo de um e do outro, através de carícias íntimas, descobrindo de forma gradativa o próprio prazer e respondendo aos sinais dos seus próprios corpos.

A concretização do ato sexual entre as mulheres desse grupo estudado delimita também a antecipação de desejos relacionados ao reconhecimento social do seu status de mulher. Assim nesse grupo podemos observar um comportamento em direção à afirmativa de Bonzon (2004) na qual refere que a autonomia sexual antecede e anuncia a autonomia social.

"A gente se conheceu quando eu saía para me diverti e lá a gente ficou se conhecendo. Depois ele falou para namorar comigo eu aceitei. Ele tinha 22 anos e eu 15 anos, quando tive minha primeira relação sexual fazia um tempão que a gente tava namorando aí pensou de ficar junto" (Vera).

O relato de Mariana não apresenta o tempo de relacionamento antes da primeira relação sexual,

"Com 16 anos foi quando tive minha primeira relação sexual que eu fugi com meu namorado. Ele não disse a idade dele, nunca, eu acho que devia ter uns trinta e oito pra 40 anos, por aí, [...]" (Mariana).

De acordo com Brandão (2004), a iniciação sexual e ou amorosa abre aos adolescentes a possibilidade de aprendizado da importância do relacionamento íntimo pertinente às diferenças de gênero, além de possibilitar a conquista gradual da sua autonomia pessoal neste momento de suas vidas.

“Ah! Com 13 anos comecei a namorar, depois de 13 em diante comecei a me desenvolver mais e ele foi o primeiro em tudo. Depois foi acontecendo, que com o adolescente acontece a coisa 
sem tá prevista, sem estar nos planos. [...] A minha primeira relação foi com os meus 14 anos [...]" (Esmeralda).

Para a autora acima citada "na relação com o parceiro do outro sexo, o aprendizado da autonomia se faz permeado pela descoberta das regras que presidem a relação entre gêneros e as dificuldades daí decorrentes" (BRANDÃO, 2004, p. 65). Para Aquino et al. (2003, p. (S383), “a entrada na sexualidade é um processo de experimentação física e relacional que se inicia antes e se estende até depois da primeira relação sexual", ou seja, esta aprendizagem é algo que vai se construindo de forma positiva na dependência de como estas relações se estabelecem e os conhecimentos vão se consolidando.

Segundo Traverso-Yepez, Pinheiro (2002), o desenvolvimento psicossocial mostrase, de máxima importância, quando se fala de prevenção e promoção da saúde, porém lamentam que estes aspectos, junto com as condições socioambientais, sejam os que são permanentemente negligenciados no modelo de saúde vigente.

Para as autoras citadas, o desenvolvimento psicossocial e a formação intelectual, moral e espiritual do adolescente são dependentes de como definem suas relações, processos de identidade e sua sexualidade, precisam de certa autonomia e, especialmente, de espaços apropriados para desenvolver a auto-estima, a criatividade e seu projeto de vida. Nesse sentido, as diretrizes do PROSAD devem satisfazer essas necessidades. De acordo com elas, o que se observa na prática é a tendência em ver os problemas dos adolescentes isolados do seu contexto social, seja a "gravidez na adolescência, as doenças sexualmente transmissíveis (DST), a violência ou a dependência química, resultando na implementação de programas verticais e isolados para cada um dos problemas" (TRAVERSO-YEPEZ, PINHEIRO, 2002, p. 142). As histórias de vida desse grupo de mulheres nos mostram que elas não tiveram acesso a um serviço de saúde que lhes orientasse sobre as vivências sexuais, menos ainda a um que se preocupasse com outras questões ligadas ao seu contexto social ou de vida.

Quanto aos relacionamentos afetivos sexuais, não observamos, neste grupo, a ocorrência de promiscuidade com trocas constantes de parceiros, a atitude de "ficar" muito presente entre os adolescentes não nos foi relatada, apenas Aparecida e Maria revelaram terem tido vários namorados. 
"Minha primeira relação foi aos 14 anos com um namorado que eu tinha. Ele tinha uns 15, 16 anos a diferença era pouca. Eu já escutava minhas amigas, que já tinha relações [...] minha mãe nunca chegou e falou quando você tiver um namorado, que você for ter relação [...] nunca tive uma orientação da minha mãe, pra ela falar sobre isso. É, tive bastante namorado, dos 14 pra os 21 só dois assim convivi com duas pessoas morando né, os outros foram namorados, eu tive uns seis namorados por aí" (Maria).

"Comecei a namorar foi com quatorze anos, que eu namorei um primo, depois deixei o primo, comecei a estudar de noite, no colégio tem muita amizade, aí arrumei outro namorado e outros namorados, perdi minha virgindade com acho que tinha quase 15 anos, não foi com meu marido, este que eu vivo, foi com outro rapaz $[\ldots] "$ (Aparecida).

Estas relações podem estar mais vinculadas à busca de viver seus sentimentos de amor e paixão com seus parceiros e a relação sexual acontece relacionada, também, ao imprevisível, como relatou Uliane: "Eu não sabia nada, não tinha noção de nada, eu não sabia e aconteceu".

Destaca-se neste grupo uma falta de preparação para a iniciação sexual e desconhecimento dos riscos a ela, levando-as a se inserirem nessa prática sem uma avaliação de sua saúde, sem uso prévio de métodos contraceptivos e de sexo seguro, sem conhecimento da família sobre sua decisão, fatores que contribuíram para que a experiência fosse vivida como fruto da situação ou do acaso. É importante registrar que os adolescentes sexualmente ativos devem ter acesso a serviços, seja de saúde ou de educação, de orientação sexual e de planejamento familiar, situação não vivenciada pelas mulheres entrevistadas.

As histórias das mulheres pesquisadas não apontam relatos de proibição nem de incentivo ou de apoio quanto ao exercício da sexualidade das jovens, também não foi observado nenhum diálogo das mães com suas filhas em busca da orientação para a preparação delas para este exercício. 
Vale destacar que uma delas teve uma iniciação sexual de forma violenta, pois aos 13 anos foi violentada por uma pessoa conhecida da família, fato que a mesma só revelou para aquele que se tornaria seu companheiro, seu segundo e atual parceiro sexual.

Evelin assim nos relatou a violência sofrida:

"Eu tinha 13 anos, minha mãe era comadre desse homem [...] ele chegou pela porta da cozinha. Aí ele entrou fechou as portas e disse: - aí eu to cansado mesmo vou entrar. Foi lá pra dentro, aí eu não fechei a porta e assim quando ele passou pela cozinha, me puxou pra o quarto e eu disse: - por que você está fazendo isso; ele disse: - cale a boca se você gritar você morre. Eu nunca contei pra ninguém, nem pra minha família porque se tivesse contado... morre a sua família e você. Ele era uma pessoa assim de idade, uma pessoa assim já com seus 40 anos. [...]. Aí fui obrigada, o cara me pegou "apusso"3, aí eu fui obrigada, e como digo, eu não achei bom nem nada, uma coisa obrigada. Eu guardei isso, depois fiquei com isso aí, quando eu fiquei com esse daí foi que contei. É contei, porque ele pensou que eu só era dele, aí eu disse - é assim, assim, assim. Foi logo quando eu conheci,ele disse: - só que eu gosto de você, quero ficar com você. Ninguém sabe só eu e ele" (Evelin).

Podemos observar que, entre as outras, a ocorrência se deu de maneira natural como conseqüência da descoberta da sexualidade através do namoro, como também gerada pela curiosidade da descoberta. Os sentimentos relacionados ao acontecimento não nos foram relatados pela maioria delas, mas encontramos situações de desconhecimento sobre o que é o sexo entre um homem e uma mulher, a curiosidade de conhecer o sexo, o arrependimento da escolha em se iniciar sexualmente.

O que podemos observar em alguns relatos é que a informação sobre sexo vem das relações sociais, ou seja, de amigas, o que pode significar que este grupo pode exercer uma pressão para que elas tenham a mesma experiência e assim manter seu espaço no grupo como nos mostra no relato de Caroline,

"Eu tive outro namorado antes de meu marido. Minha primeira relação foi com 14 anos.[...]. Aí quando foi eu arrumei um

${ }^{3}$ À força 
namorado, e depois do acontecido foi que eu descobri que ele usava droga aí eu peguei e o deixei. Só que foi horrível assim porque foi só por curiosidade e eu não gostava dele, que minhas colegas sempre falavam: - é bom, vai que você ver você vai gostar; aí eu peguei fiz. Porque eu imaginava que mesmo tendo acontecido, eu poderia voltar a ser virgem novamente, mais eu vi que não era assim, que aconteceu pronto é uma coisa que nunca mais poderia ter de volta a minha virgindade, é uma coisa que eu me arrependi muito depois que aconteceu" (Caroline).

Quanto à idade dos parceiros, alguns eram mais velhos que elas, mas a maioria também era adolescente ou adulto jovem. Mariana e Evelin, em contextos distintos, tiveram sua primeira relação com homens bem mais velhos que elas.

Para Brandão (2004), a escolha de um parceiro no mercado matrimonial está relacionado à diferença de idade, e a superioridade social do parceiro. Nos relatos das mulheres participantes em nossa pesquisa, a diferença de idade está presente em todas elas. A superioridade social dos namorados pode ser vista por elas como maior capacidade para se inserir no mercado de trabalho ou pelo fato de alguns já estarem inseridos. Este fato pode torná-los homens para futuros compromissos, ou seja, com possibilidades de se tornaram seus parceiros conjugais.

\section{Uso de contraceptivo}

Com respeito à orientação familiar, Brandão (2004, p.69) afirma que o "diálogo entre pais e filhos é muito complexo exprimindo a tensão entre afirmação da heteronomia e respeito à autonomia juvenil". Ela afirma que atualmente existe um imperativo social que sugere não ser mais possível educar os filhos sem abordar o tema da sexualidade, porém é difícil a construção de um diálogo em que pais e filhos estejam no mesmo nível.

As histórias relatadas mostram a ausência que as mulheres pesquisadas sentiram acerca da orientação recebida de suas mães sobre anticoncepção, fato considerado por elas como importante para a prevenção da gravidez. Na opinião de Evelin, "As moças de hoje [...] sabe um pouquinho que as mães ensinam um pouquinho”, porém ela nos relata que: 
“[...] minha mãe nunca me ensinou nada, quando vinha o povo mais velho conversar mandava sair, - vai embora pra dentro, quando o pessoal conversava na sala mandava eu sair perto dela" (Evelin).

"[...] minha mãe nunca chegou e falou quando você tiver um namorado, que você for ter relação, a minha mãe nunca me disse isso, eu nunca tive uma orientação da minha mãe, pra ela falar sobre isso" (Maria)..

O relato de Aparecida é objetivo quanto ao assunto,

"[...] a minha mãe nunca sentou com a gente pra dizer olha é isso, houve isso, use isso e isso, que nem hoje em dia existe camisinha, existe remédio, mas a minha mãe nunca falou pra mim, nem de menstruação, nem de nada. [...]" (Aparecida).

Esta narrativa mostra a importância da mãe no processo de orientação e a falta que sentiram desta comunicação e vai ao encontro dos resultados apresentados por Wagner et al. (2002) sobre a forma como os adolescentes avaliam a comunicação que mantém com cada um dos membros de sua família, em que se observou que a mãe é citada, pela maioria dos adolescentes, como a pessoa da família com quem eles mais conversam, sendo considerada uma pessoa muito coerente e com grande capacidade de entendimento.

Algumas mulheres relataram que conheciam os métodos contraceptivos e faziam uso deles quando iniciaram sua vida sexual, entretanto tiveram dificuldades no uso devido ao exercício de sua sexualidade ser algo não assumido perante a família. Outro fator que dificultou seu uso foi a imaturidade própria da idade que, na maioria das vezes, impediu-as de uma tomada de decisão consciente sobre o exercício, considerando a vulnerabilidade a uma possível gravidez e mesmo a infecções sexualmente transmitidas (IST). Como poderemos observar nos relatos abaixo:

"Sabia como evitar, eu evitei muitas vezes, usava preservativo que era escondido de minha mãe, tinha vez que eu não usava aí foi quando eu engravidei, mas também sabia de comprimido, mas não podia que era escondido. Minha mãe não sabia de nada" (Tieta). 
Observamos a descontinuidade do método relatado por Tieta, a mesma usava descontinuadamente o preservativo e o fato da clandestinidade das relações sexuais a impediu ou dificultou a escolha de outro método, aqui vemos que ela não fala sobre o parceiro já que quem usa o preservativo é ele, assumindo a responsabilidade pela descontinuidade e por não poder optar por outro método.

"Comecei a usar remédio, pílula e depois fiquei usando camisinha, eu era muito novinha, era uma bobinha sapeca, tá sabendo, e agora depois com o tempo eu fiquei mais esperta, porque eu passei a entender a vida" (Orquídea).

“[...] eu comprava e tomava os comprimidos. Nesta época você não se liga pra aquela responsabilidade de tomar os remédios como tem que ser, eu nunca me incomodei em saber melhor como é que tomava, como evitava e vai vivendo a relação" (Uliane).

Os serviços de saúde e de educação não foram relatados pelas mulheres como instituições de importância na educação sexual, fato que demonstra que não tiveram acesso a serviços qualificados nos quais poderiam ter recebido as informações sobre sexualidade e planejamento familiar, suprindo a falta sentida no seu cotidiano familiar e principalmente com as mães.

Observamos, também, uma ausência do parceiro nesta questão da anticoncepção evidenciando que neste grupo a responsabilidade pelo controle da reprodução é restrita às mulheres. Como podemos observar na fala de Vitória,

"Eu tentei evitar de todo jeito, mais só que não dava, pegava preservativo lá, mais ele não quer usar de jeito nenhum, com ele não dá certo sabe, ele é muito agoniado. Porque tem o dia certo da pessoa engravidar e eu sempre dizia a ele: - hoje eu não quero; e ele é muito teimoso, só acredita depois que eu engravido. [...] Eu acho que depende da outra pessoa também" (Vitória).

Como a maioria das relações sexuais acontecia associada a uma relação afetiva, a prática de sexo seguro e vulnerabilidade a infecções sexualmente transmissível em nenhum momento são abordadas. Com Taís na primeira relação "A gente não usou preservativo nem nada, mas eu não engravidei, não, da primeira vez não [...]”. 
"Essas coisas eu sabia pouco, porque minha mãe não conversava muito comigo, eu vivia mais com meu pai e também eu não gostava de perguntar a minha madrasta, porque eu tinha vergonha, fui aprendendo assim aos poucos uma pessoa dizia uma coisa, dizia outra e eu aprendi mais coisas quando eu comecei a namorar ele que a minha sogra conversava comigo [...]" (Leônia).

Com esses fatos relatados, podemos inferir que não foi por falta total de conhecimento dos métodos contraceptivos que as mesmas não os utilizavam, mas observase que elas não têm consciência de sua vulnerabilidade, fato que pode estar associado ao desconhecimento da fisiologia reprodutiva que provavelmente dificultava-as em identificar o seu período fértil e dessa forma escolher e usar um método contraceptivo de maneira responsável.

Outra situação que verificamos é que as diretrizes propostas pelo PAISM estão longe da realidade desse grupo estudado, porque antes do PSF que se implantou nesta comunidade, em 1997, o acesso ao serviço de saúde era muito difícil e dessa forma não era buscado em situações que não se referissem à doença. Esse fato pode ter contribuído para que o acesso à informação e aos métodos contraceptivos fossem deficientes nesta comunidade. Entretanto a implantação do PSF não garantiu o direito pleno aos métodos contraceptivos, porque a disponibilidade se restringiu ao anticoncepcional oral e ao preservativo masculino, não permitindo a estas mulheres a livre escolha do método que mais se adequasse ao seu desejo. Além disso, não existia um programa de atenção ao adolescente implantado e algumas tentativas de formação de grupo de adolescentes para orientação não atingiriam a comunidade como um todo, incluindo as mulheres estudadas.

Apesar de algumas mulheres relatarem o desejo pela maternidade, elas relatam que no momento de sua ocorrência ela foi fruto da desinformação quanto ao uso de métodos contraceptivos, assim como a dificuldade do uso destes métodos por ser o exercício da sexualidade não assumido perante a família.

Taís justifica a gravidez não pela falta do uso de algum método, mas o fato de que, teoricamente, talvez estivesse segura por estar menstruada.

"Ah, quando eu arranjei um namorado, foi a primeira coisa que aconteceu foi engravidar, sabia que tinha que tomar comprimido, 
usar camisinha, mas eu não fiz nada disso, mas eu não esperava, porque quando eu engravidei da primeira vez eu estava menstruada, eu acho que eu estava menstruada" (Taís).

Isadora afirma que usava comprimido quando engravidou, sugerindo que o mesmo deve ter falhado, mas apresenta uma postura responsável presente em todo o seu relato que demonstra a falta que sentiu de uma orientação,

"Eles não foram planejados. Na segunda eu evitava, tomava remédio só que eu engravidei. E da primeira também eu tomava remédio, mas só que eu não sabia, não entendia como era, não tive ninguém pra me explicar, aí mesmo eu tomando remédio eu já tava grávida da menina, e o menino foi a mesma coisa" (Isadora).

Brandão (2004, p.78) afirma que o acesso à informação nos faz pressupor que o jovem transformaria sua prática sexual, adotando uma postura de autoproteção que eliminaria os riscos inerentes a esse comportamento, entretanto "o manejo e a adoção dos métodos são lentos, exigem discussão com os parceiros, autoconfiança, apoio social", o que sabemos não é o caso neste grupo que não tem informação e o apoio social nem da família nem do Estado, os quais deveriam estar mais presentes junto a esse grupo, pelas características próprias da idade.

Essa realidade contraria o exposto no art. 226 em seu parágrafo $7^{\circ}$ da nossa Constituição Federal de 1988 (BRASIL, 2005) que prevê:

Fundado nos princípios da dignidade da pessoa humana e da paternidade responsável, o planejamento familiar é livre decisão do casal, competindo ao Estado propiciar recursos educacionais e científicos para o exercício deste direito, vedada qualquer forma coercitiva por parte das instituições oficiais ou privadas. (BRASIL, 2005, p. 237).

Segundo Giffin e Costa (1999), as mulheres brasileiras experimentam altas taxas de fracasso com métodos que, se fossem utilizados de maneira correta, lhes dariam elevado índice de proteção contra uma gravidez não planejada. Essa afirmativa também é confirmada em pesquisa sobre o uso de contraceptivos realizada com gestantes adolescentes, residentes em um grande centro urbano do Sudeste do país, em que as “adolescentes grávidas têm conhecimento elevado em relação à existência de métodos anticoncepcionais, embora uma prática inadequada para sua utilização" (GIFFIN; COSTA 1999, p. 485). 
Situação semelhante que podemos observar no relato de Caroline

“Aconteceu porque eu não sabia como era que evitava, já foi a minha cunhada que falou que eu tinha que tomar comprimido e me ensinou como tomava os comprimidos pra evitar. Ensinou-me como é que usava preservativo, a camisinha no caso, eu não sabia como era. Aí foi por acidente a $2^{\mathrm{a}}$. e a $3^{\mathrm{a}}$. gravidez. Se minha cunhada não tivesse me ensinado, eu acho que já tava com uns cinco filhos. Eu pensava assim que só tomava o comprimido quando ia ter relação" (Caroline).

Para Belo e Pinto e Silva (2004), os jovens que residem nos centros urbanos mais desenvolvidos têm maior acesso à escola, a serviços de saúde de melhor qualidade e às informações da mídia, situação que garantiria melhor e maior conhecimento, o que não é o caso do grupo de mulheres alvo de nossa pesquisa, que apesar de residirem na capital de um Estado, vivem à margem da informação.

O estudo de Aquino et al. (2003) verificou que, entre jovens, há uma tendência ao relaxamento nas práticas de proteção para a gravidez, na medida em que se consolidam relacionamentos mais estáveis, situação que, em parte, corrobora com as experiências vividas pelas participantes do nosso estudo.

Com as falhas no uso de anticoncepcional oral e do preservativo, as mulheres de nosso estudo foram motivadas a fazer o controle de sua reprodução através da esterilização cirúrgica.

A opção pela laqueadura tubária está presente na vida dessas mulheres que vêem nela a opção de não terem mais filhos. As razões para esta opção estão relacionadas ao objetivo de terem possibilidade de ter melhores condições para criar os filhos tidos frente à situação econômica em que vivem, acrescido da falta de opção de métodos que se adeqüe melhor às suas necessidades. Nenhuma delas apontou o controle da reprodução como uma possibilidade de ampliar as oportunidades em suas vidas. As condições econômicas também foram encontradas por Marcolino e Galastro (2001) como fatores que justificam a limitação do número de filhos.

"Não, não recebi orientação nenhuma. Eu nunca evitei porque enjoou o comprimido, se eu tomar eu fico em tempo de morrer aí 
eu não tomo. E não tenho condições de tá tomando injeção, eu também nunca evitei, nunca usei camisinha, nem nada, agora é que eu não uso mesmo, eu não gosto, comprimido eu não posso tomar, e injeção eu não tenho condições de tomar e camisinha não quero aí não dá. Eu não quero mais ter filho. Eu penso em me operar, pra não ter mais. É a única opção de não ter muito filho eu já tenho ela e esse, vai eu ter mais, sem condições, eu não posso, pra botar eles no mundo pra fica sofrendo também eu não quero, não é? Eu penso em me operar pra não ter mais" (Taís).

"Porque meu marido nunca compra comprimido pra evitar, se pega camisinha no Posto ele também não quer usar [...]. Tenho que me operar apusso [...] ele disse que me operava depois que eu tivesse a menina, aí eu também não queria ir pro médico duas vezes, ir, voltar e depois voltar" (Vitória).

“[...] hoje em dia eu quero me operar, mas negócio de candidato eu não quero, tem um candidato que já levou bem umas quarenta mulheres para se operar. Eu não tenho muita sorte na vida para depois ficar doente. Eu quero me operar, mas direito, tomo remédio de novo, passo mais um ano tomando remédio como a médica já disse, depois eu me opero" (Aparecida).

Marcolino e Galastro (2001) afirmam que os significados dos métodos definitivos são diferentes para homens e mulheres. Enquanto para a mulher a cirurgia representa o método mais seguro e eficaz para limitar o número de filhos, após terem vivenciado o uso de métodos contraceptivos temporários, principalmente o anticoncepcional oral. Para o homem que provavelmente já se encontra inserido no mercado de trabalho, o encerramento da paternidade significa mais liberdade, lazer e convívio com os filhos.

Elas afirmam também que para a mulher "o apelo para o método cirúrgico representa uma indisposição em continuar assumindo a contracepção de maneira solitária, sem a colaboração do companheiro" (MARCOLINO E GALASTRO, 2001, p.79). Outra possibilidade identificada pelas autoras é a da mulher "ser-trabalhador", podendo fazer parte do mundo público, contribuindo para a renda da família e para uma melhor qualidade 
de vida" (MARCOLINO E GALASTRO, 2001, p.79), fato este que não identificamos em nossos relatos.

As mulheres estudadas também abordaram o desejo de se inserirem no mercado de trabalho como um projeto de futuro, mas não apontam a cirurgia como um fator que lhes desse possibilidade para isso, afirmando que a limitação do número de filhos, a prevenção de uma gravidez indesejada e as condições econômicas em que vivem são os pontos fundamentais.

Uliane e Tieta já haviam realizado a laqueadura, mesmo sendo as duas muito jovens com 20 anos de idade, cada uma delas com dois filhos e a motivação delas foi financeira. Assim a condição econômica apresenta-se como um fator determinante no desejo de realizar a esterilização cirúrgica para limitar o número de filhos ou para interromper a vida reprodutiva. Vejamos os relatos delas:

"Eu me operei não foi por medo de ter filho, de ter eu não tenho porque graças a Deus eu tive uma gravidez boa e um parto também, eu tenho medo de não poder criar, de não poder dar o que eles merecem, dar educação boa e alimentação, é esse o meu medo, não de ter filho, ter filho até uns 10 , o meu medo é de não poder dar educação você com dois filhos você ainda pode dar o necessário básico pra eles, dar um conforto [...]”' (Uliane).

"Eu decidi me operar por causa da situação financeira, que o remédio que eu tomava era muito caro e a gente todo mês não tinha condição de comprar. Meu marido começou a trabalhar agora há pouco e a gente passou um bom tempo apertado, porque ele parado, a gente só dependendo da minha mãe pra tudo. [...] eu me operando é melhor que eu não queria mais filho mesmo, aí eu meti o peito pra me operar, porque não tinha condição mais de engravidar, acho que eu não tenho mais paciência de ter mais filho" (Tieta).

Aparecida teve mais duas gravidezes, desejadas, pela vontade de ter um filho homem, o que aconteceu na sua terceira gravidez, agora deseja realizar a laqueadura. Maria gostaria de fazê-la, mas tem muitas dúvidas, entre elas verificamos que a possibilidade de uma nova união que traria o desejo de um filho e outra é o desejo de ter um filho homem, 
mostrando como o sexo masculino é valorizado pelas mulheres. Isadora também faz referência a ter um casal de filhos e por isso não necessita mais engravidar, assim coloca a opção de realizar uma laqueadura tubária em futuro próximo, mesmo sem estar com um namorado no momento. A fala de Maria relata esta questão:

“Tenho 21 anos, agora no dia 8 de novembro faço 22 anos, minha mãe quer que eu me opere pra não ter mais. Eu penso de me operar, mas penso de me arrepender. Penso de ficar grávida novamente vê se vem um menino $[\ldots]$ se vier outra menina eu me opero $[\ldots]$ posso conhecer outra pessoa, for morar e dá certo o que ela vai cobrar de mim, cobrar um filho, eu não vou poder dá, por ter me operado nova. Eu fico pensando tudo isso. Vai que eu conheça uma pessoa e não posso dar mais filho. Com 21 anos, operada, fico pensando. Eu penso, penso tanta coisa" (Maria).

As narrativas apontam que elas não desejam mais filhos e parece que a opção definitiva oferecida pela esterilização cirúrgica é a única que lhes dará segurança de não mais engravidar. Essa opção não se encontra vinculada ao número de filhos tidos nem à idade da mãe, pois as mulheres mais jovens da pesquisa já haviam feito a laqueadura e ambas tinham dois filhos.

Nos relatos das mulheres, encontramos pouca participação dos homens na decisão acerca dos métodos contraceptivos a serem usados pelo casal. Uliane relata que seu esposo aprovou a idéia devido a ela passar mal com o uso do contraceptivo oral, mas não faz menção de esta decisão ter sido conjunta.

"Ele achou bom também que eu tomava comprimido e tava com gastrite de tanto comprimido, tomava o comprimido e passava a noite toda sem dormir com aquela dor no estômago e também não podia tá me acabando por causa do comprimido tinha que arrumar outro jeito. Aí consegui me operar, me operei” (Uliane).

Elas assumem a responsabilidade pela escolha do método contraceptivo, apesar da escolha de um método estar relacionada à vida sexual dos dois e que deveria ser compartilhada por ambos, mas parece ser uma decisão exclusiva das mulheres. 
Observamos em um depoimento que existe no Estado o uso político da laqueadura tubária, sendo esta outra realidade presente nesta comunidade e que nos foi relatada por Aparecida que não a desejava dessa forma por acreditar que poderia correr algum risco em sua saúde.

Berquó e Cavenaghi (2003), em pesquisa realizada em cinco capitais das regiões brasileiras para analisar os impactos e as possíveis mudanças que a implementação da nova legislação sobre planejamento familiar teve nas práticas reprodutivas, especialmente após a implantação da esterilização voluntária no SUS, verificaram que após um seguimento de aproximadamente seis meses, apenas $25,8 \%$ das mulheres que demandaram esterilização tiveram sucesso. Dentre os homens, 31,0\% conseguiram a vasectomia. Esses resultados mostram a dificuldade de se atender à demanda e motivam o uso político deste procedimento, como uma via de menor burocracia, atendendo à necessidade das mulheres de interromper de forma definitiva sua vida reprodutiva.

Constatamos que as mulheres desse grupo ainda têm um longo percurso a fazer para conquistar o que está estabelecido como direitos sexuais e reprodutivos, neste momento elas se encontram cada uma lutando e buscando de forma individual um espaço dentro desta falta da estrutura dos serviços públicos para atender às suas necessidades de controlar sua vida reprodutiva e ao que nos parece este discurso comum de buscar a laqueadura tubária é uma outra forma de mostrar as condições de desigualdades em que elas vivem. Elas acabam não tendo condições de exercer o seu direito reprodutivo, tendo direito de ter uma vida sexual que lhes satisfaça sem riscos de engravidar, se assim o desejar. Ter direito é ter poder, e elas mais uma vez se vêem subtraídas dele.

\subsection{EVIDENCIANDO AS HISTÓRIAS DA MATERNIDADE NA} ADOLESCÊNCIA

A gravidez e a maternidade na adolescência, consideradas como precoces, sendo planejadas ou não resultam em uma tomada de decisões quanto ao futuro pelas pessoas envolvidas neste episódio. Decisões estas que trazem conseqüências para a vida dessas 
mulheres, seus parceiros e filhos. A análise dos fragmentos das narrativas consiste em reconhecer a mulher e a maternidade, a partir da sua própria compreensão e interpretação.

\subsubsection{MATERNIDADE NA ADOLESCÊNCIA}

\section{A maternidade na adolescência}

A maternidade entre as mulheres de nosso estudo ocorreu em uma fase da vida de aprendizado acerca do exercício da sexualidade e como afirmam Aquino et al. (2003, p. S378) existe o pressuposto de que a gravidez na adolescência "é vivida de múltiplas formas e os contextos sociais definem universos de possibilidades e de significações diferentes entre os jovens de distintas classes sociais".

Para Catharino e Giffin (2002, p. 7), em pesquisa sobre gravidez na adolescência com adolescentes de 10 a 14 anos de idade e usuárias do SUS, ser mãe entre elas "talvez seja uma das poucas formas que lhes restam no sentido de se colocarem no mundo como sujeitos sociais".

Nos relatos das mulheres de nossa pesquisa, encontramos que estas jovens sonham com a maternidade, apresentando uma visão romantizada, usando expressões como: a beleza de ser mãe, o desejo de formar sua própria família, e a felicidade de se descobrir grávida. Apesar deste desejo, atualmente elas revelam a contradição em que vivem, pois apesar de terem sonhado em ser mães, algumas delas, analisando a situação atual, afirmam que deveriam ter se dedicado mais aos estudos ou esperado mais tempo antes de engravidar.

"Com 16 anos eu sonhava, achava bonito ser mãe, ainda acho, mas eu devia ter me dedicado mais aos estudos. Era muito nova para ser mãe, tô realizada, mas se eu fosse mais velha tava ganhando meu dinheiro" (Orquídea).

"Eu tinha uns 13 anos quando eu vim pensar mesmo de arrumar uma pessoa pra viver, pra casar mesmo" (Leônia).

"Eu gostei, eu fiquei feliz, oche! Eu fiquei muito feliz, eu era doida pra ser mãe" (Mariana). 
Este desejo nos é revelado por Evelin, que o teve fortalecido pelo cotidiano em que estava inserida, pois ela revela que quando era babá e cuidava dos filhos dos outros, pensava em ser mãe e sentia inveja das mulheres que andavam com seus filhos. Ela era jovem, havia vindo para Maceió para trabalhar em "casa de família", estava longe de sua família nuclear e este desejo pode vir da necessidade de afeto de ser reconhecida, manifestada na vontade de ser mãe e assim ter sua própria família.

"Quando eu comecei namorar disse: - vou casar agora, vou casar pra viver feliz, vou casar pra ter família, pra deixar de trabalhar nas cozinhas do povo, essas coisas assim" (Evelin).

Taís fala do seu desejo de engravidar fazendo referência à sua segunda gravidez, pois acreditava que com a gravidez sua vida tomaria outro rumo. A relação estabelecida com seu segundo parceiro foi diferente da primeira, quando engravidou, e o pai não tomou conhecimento, ficando sozinha durante toda a gestação e parto.

"Eu engravidei logo dela, eu fiz de tudo pra engravidar logo dela, aí minha vida começou a entrar nos eixos, porque eu vim logo morar aqui [...] depois que eu engravidei dela aí a gente ficou aqui, eu num saía" (Taís).

O desejo de ser mãe nem sempre era compartilhado com a família, e elas relatam o medo de que gravidez que não foi planejada pelo casal e não era esperada pela família não fosse aceita, deixando transparecer a fragilidade das relações que estas adolescentes vivenciaram e a situação de insegurança quanto ao seu futuro após gravidez. As narrativas demonstram a dependência econômica que elas tenham de suas famílias, portanto aceitação era de fundamental importância para sua estabilidade emocional. Foi o que nos revelou Tieta,

"Eu fiquei alegre, porque eu sempre quis ter um menino, que eu gostava muito, gosto muito de criança, eu fiquei alegre. Agora o meu medo maior foi que a minha mãe soubesse e não aceitasse, mas ela aceitou" (Tieta).

As histórias de vida apontam ainda que a gravidez nesse grupo, mesmo sendo precoce, era considerada como o rito de passagem para a vida adulta, como relata Esmeralda, que passou a sentir-se mais madura depois da gravidez e revela o amor que tem 
pelo parceiro e a importância para ela, como mulher, em ter um companheiro para compartilhar a vida.

“Aí foi quando eu fiquei grávida pela primeira vez. [...] eu me senti mais madura por ser mãe nova, é só, foi isso mesmo. Foi bom porque tive uma pessoa certa, porque pra um homem morar com uma mulher hoje isso é muito difícil. Tem mais? Eu o adoro" (Esmeralda).

O contexto em que estas meninas viviam, o baixo rendimento escolar e a inserção precoce no mercado informal de trabalho se apresentaram como fortes indicadores para que elas identificassem na gravidez, numa fase precoce, uma forma de serem reconhecidas socialmente. A construção da identidade materna continuou se constituindo, em suas vidas, pelas possibilidades ou impossibilidades de fazer projetos de vida futura bem como na sua concretização. Observamos que as mulheres estudadas não têm oportunidades que lhes favoreçam estabelecer novos desejos além de se realizarem no contexto do mundo doméstico.

Apesar do desejo de serem mães, para a maioria das mulheres de nosso estudo, a primeira gravidez não foi planejada e elas não pretendiam engravidar, na ocasião de sua ocorrência Vitória nos contou que nem pensava em ser mãe. O conhecimento da gravidez, entretanto, para a maioria, apesar de não desejável foi aceita como um fato natural.

"Eu tive, eu fiquei feliz, nunca pensei em nada não, nunca pensei em fazer nada não, quando descobri só fiquei feliz. Ele ficou feliz também ele" (Evelin).

"Engravidei aos 14 não foi uma coisa planejada, pois acho que ninguém engravida aos 14 planejando. Não foi uma gravidez que eu tivesse esperado, pra mim foi um susto quando eu soube que tava grávida, mas encarei [...], era praticamente uma criança ainda, não tinha noção realmente ainda do que ia acontecer, mas pra mim eu acho que foi uma das maiores coisas, hoje em dia a melhor coisa que podia ter acontecido na minha vida foi o meu filho. Porque posso me arrepender do que for, mas não dos meus filhos, não posso dizer eu me arrependo de ter tido eles. Eles não pediram para 
vir ao mundo, foi um erro meu, não foi uma coisa planejada" (Uliane).

"Eu nunca nem que quis engravidar na minha vida. Eu nunca tive vontade de filho não, ter só um, só um mesmo" (Vitória).

As histórias de vida não apontam intercorrências obstétricas na primeira gravidez destas mulheres, contrapondo à afirmativa de Camarano (1998b, p. 44) sobre "incapacidade fisiológica para gestar e incapacidade psicológica para criar" das adolescentes.

Por ocasião da primeira gravidez, algumas das mulheres já se encontravam morando com seus parceiros, a maioria delas passou a coabitar com o parceiro após a gravidez. Formando um novo núcleo familiar ou então convivendo com familiares, apenas Taís permaneceu sozinha, indo se unir a um homem a partir de sua segunda gravidez.

“[...] eu apareci grávida, aí ele foi logo ajeitando a casa lá e o quartinho pra gente, aí eu passei a conviver com ele [...]" (Leônia).

"Quando eu engravidei pela primeira vez, eu já morava com meu marido, eu não pensei que estava grávida, foi assim de repente como menos esperava estava grávida, aí não tinha mais como evitar e deixei vir" (Vera).

"Eu engravidei com 19 anos e achei bom, foi bom porque a gente planejou porque a gente estava namorando. A gente se conheceu assim..., mas eu engravidei muito cedo, a gente tava acho que com uns dois meses de namoro. Eu o conheci em agosto, quando foi em novembro eu fui morar com ele aí já tava grávida" (Mariana).

Aquino et al. (2003), em pesquisa multicêntrica realizada no Brasil, encontraram nos grupos de homens e mulheres pesquisados que a primeira gravidez, na maioria das vezes, se deu fora de uma união conjugal. Seus resultados apontam que $6,6 \%$ dos homens e $74,2 \%$ das mulheres, ao engravidarem antes dos vinte anos, moravam ainda com suas famílias de origem.

Entre as mulheres de nosso estudo, destaca-se o fato de que, apesar das gravidezes não terem sido planejadas e terem ocorrido, na sua maioria, fora de uma união conjugal, 
elas foram assumidas pelos parceiros, que em muitos casos demonstravam aprovação sobre a ocorrência.

Bruno e Bailey (1998) afirmam ser um engano assumir que toda gravidez ocorrida na adolescência seja indesejada, segundo elas "muitas são, sim, desejadas e planejadas" (p.65), como no caso de Maria, "Eu engravidei com 15 anos porque eu quis. Porque eu queria uma menina" e Caroline nos conta que, "A primeira gravidez eu quis, eu gostei $[\ldots] ”$.

Apesar de não terem planejado e, em alguns casos, terem tido dificuldade em aceitá-la, todas levaram a gravidez a termo, sendo também assumidas pelos parceiros, com exceção do parceiro de Taís, que não tomou conhecimento da gravidez e parto por ter se ausentado da cidade,

"O pai, êita meu Deus tinha ido embora e ele nem sabia. Ele disse que soube depois, muito depois, depois que ele morreu e tudo foi que ele soube mais não disse nada, não comentou se queria nem se não queria, nem fez questão que ele tinha morrido nem nada" (Taís).

Identificamos que o conhecimento da gravidez foi recebido, algumas vezes, com sentimentos negativos como susto, coisa ruim, péssima de acontecer, que não se estava preparada para engravidar naquele momento, algo que geraria mudanças na vida e que trazia consigo mais responsabilidades.

"Mudou bastante minha vida, tenho mais responsabilidade coisa que eu não tinha, minha mãe trabalhava e me deixava em casa com as minhas duas irmãs, eu tinha que organizar tudo, mas a responsabilidade aumentou agora que eu tinha duas crianças pra cuidar, pra educar, pra tudo. Mudou, não é quando a pessoa casa, que sabe que aquilo vai acontecer. Que aquilo já tá traçado, você casa, você sabe que mais pra frente você vai ter um filho, você vai ter que cuidar dele e ter responsabilidade com tudo. E eu não, foi de repente" (Isadora).

Encontramos algumas situações em que a gestação foi considerada indesejável e as mulheres manifestaram tentativas de abortar. É importante ressaltar que o desejo e, em 
alguns casos, as tentativas de abortarem estiveram relacionados à não-aceitação da gravidez por pessoas de suas relações, em alguns casos, as mães de seus companheiros e os próprios que, inclusive, ajudaram nas ações relacionadas às tentativas de abortamento. Observamos que esta não-aceitação passou pela não-aceitação por parte do companheiro, no caso de Taís, como já colocamos anteriormente, o pai de seu filho não chegou a saber de sua gravidez.

“[...] eu digo, a minha primeira gravidez eu não queria, mas não sabia como abortar, eu tomei um monte de remédio de mato que a mulher passou pra eu tomar. Mas acabou vindo e a minha mãe pegou ele, eu acho que ela não sabia tomar conta do menino, que ele acabou morrendo, aí eu fiquei sozinha fiquei meio doida do juízo, mas depois voltei ao normal" (Taís).

Observa-se, entretanto, que nenhuma dessas tentativas de aborto foi bem-sucedida. A maioria das mulheres fez uso de preparados caseiros e uma delas tomou Cytotec. A indução do aborto foi sempre malsucedida e a escolha do método para abortar esteve relacionada com suas dificuldades econômicas que as impediram de ter acesso a métodos mais eficazes e seguros.

Caroline desejava sua primeira gravidez, mas devido à condição financeira em que vivia, seu parceiro não aceitou esta gravidez e neste caso a iniciativa pelo aborto na primeira gravidez foi dele e ela, apesar de querer o filho, se submeteu a ele, ingerindo os chás que ele preparava. Neste ponto encontramos o parceiro usando o aborto como forma de controle da fertilidade.

“[...] só que meu marido não queria aceitar não, que ele disse que não tava com dois meses que a gente tava junto, morando dentro de casa, ele queria que eu fizesse um aborto.[...]. Ele disse que aceitava, mas, quando eu vim pra cá, ele começou a fazer um monte de chá pra eu tomar, eu tomava, porque ele tava a mais de um ano desempregado. [...] da $2^{\text {a }}$. gravidez eu que tomei remédio escondido pra abortar, da $2^{\mathrm{a}}$. e da $3^{\mathrm{a}}$. também eu tomei" (Caroline).

No caso de Tieta, a sogra foi quem teve a iniciativa de dar-lhe algo para abortar, talvez na busca de "liberar" seu filho de um compromisso precoce, 
“A minha sogra me deu remédio para eu abortar a menina, aí eu tomei, eu não sabia e tomei, ela disse que foi ele, mas não foi ele que mandou que ele tava viajando, minha sorte foi que eu botei todinho pra fora, aí não teve nada, mas eu adoeci e minha mãe me levou para o pronto-socorro. [...]" (Tieta).

Os depoimentos são carregados de fortes emoções e evidenciam os riscos à saúde a que essas mulheres estiveram expostas nas tentativas de aborto com métodos inseguros.

A rejeição à gravidez de Taís e Aparecida estava, também, ligada ao dos parceiros não terem assumido a gravidez.

"Antes eu tinha tomado um bocado de remédio para tirar a Bárbara. Nova eu, não queria, não tinha caso, não tinha marido, eu não minto não, tomei remédio para matar, mas só que não deu [...]. Na minha cabeça eu sabia o que eu tinta feito, estava com remorso que eu tinha tomado remédio porque que eu não queria, se nascesse esse neném, ia atrasar minha vida, dito e feito" (Aparecida).

A falta de planejamento dessas gravidezes pode estar relacionada ao que Monteiro (2002) discute sobre sexualidade, cujas ações sociais não são resultados de um planejamento racional, mas $\operatorname{sim}$ a reprodução de comportamentos aprendidos e internalizados. Nos relatos destas mulheres, não encontramos nenhuma informação sobre suas mães terem sido mães solteiras e dessa forma a experiência da maternidade vivida por elas prescinde de uma relação estabelecida entre os parceiros. Assim na construção de sua identidade, a aprendizagem relacionada com a maternidade está estabelecida dentro de uma construção de família e como afirma Giffin (1999) a subjetividade do feminino é coletiva.

De acordo com Giffin e Costa (1999), apesar do alto número de abortos bemsucedidos, no Brasil, alguns estudos mostram que as tentativas de aborto são ainda mais numerosas. Verificamos, entre as mulheres estudadas, que a maioria das tentativas de abortos aconteceu na primeira gravidez. Apenas Coroline e Leônia tentaram abortar em suas gravidezes posteriores, também por razões econômicas e devido à situação conjugal, mas também não obtiveram êxito. Leônia tomou medicamento para abortar, foi internada em uma maternidade com sangramento, quando estava com 11 semanas de gestação e ela nos conta que: 
"Fiquei um ano e um mês separada dele, aí depois conheci uma pessoa, engravidei, tentei abortar, mas não consegui [...] Tomei oito Cytotec e não resolveu porque era de Deus, tinha que vim, porque era uma vida." (Leônia).

A ocorrência de abortos registrados no DATASUS, de janeiro a novembro de 2004, no estado de Alagoas, foi na ordem de 5.258 casos com $61,1 \%$ deles ocorrendo em Maceió. A distribuição por faixa etária foi 1,7\% (56) na faixa de 10 a 14 anos de idade e $21,6 \%$ (696) na faixa de 15 a 19 anos, dado superior ao encontrado na faixa de 30 a 34 anos que foi de 17,5 (564), sendo o maior percentual encontrado na faixa de 20 a 29 anos que foi de 57,0\% (1831) (BRASIL, 2004).

Observamos que, apesar das leis restritivas em relação ao aborto, a falta de acesso a serviços de saúde de qualidade aliado à não-implantação de programas de planejamento familiar, o aborto continua sendo uma realidade e apesar de, nesse grupo, ter poucas repercussões físicas, as repercussões emocionais como a culpa e a recriminação do ato estão presentes nas narrativas.

Encontramos, também, a reincidência de gravidez na história de todas as mulheres, com exceção de Mariana. A média de filhos entre elas foi 2,64 por mulheres, variando de um a cinco, Evelin que tinha apenas uma filha, na segunda entrevista estava na sua segunda gravidez e Vitória com quatro filhos também se encontrava grávida e relatava ter tido um aborto, alguns meses antes. Algumas relataram que não acharam ruim as gravidezes subseqüentes, apesar de, novamente, a maioria não ter sido planejada, mas foi aceita, sem que elas expressassem nenhum sentimento de ressentimento quanto a esta(s) ocorrência(s).

Tieta, entretanto, responsabiliza o parceiro por esta nova gravidez. Vejamos algumas falas sobre esta questão:

“[...] só que a segunda já não foi como eu queira, aconteceu, a terceira gravidez também. [...] A gente não pensou pra ter logo três filhos, um atrás do outro. Eu estou tomando comprimido pra não engravidar outra vez porque se eu engravidar, pronto é o fim. E ele também não quer, e não quero mais filho, já chega esses três" (Caroline). 
"[...] eu engravidei da segunda porque ele tirou o preservativo... eu morava na casa da minha mãe, a gente de noite quando eu dei fé ele já tinha tirado o preservativo, aí foi quando ele gozou, quando eu percebi não podia fazer nada. Tomei remédio mas não teve jeito, a menina eu acho que já tava, eu tava no período fértil, que eu fiquei grávida, eu não sei porque, ele disse que não foi ele, mas não tem condições de um preservativo sair sem a pessoa tirar, eu até fiquei com raiva dele a gente tava pra se separar" (Tieta).

“A segunda gravidez também não foi uma coisa esperada [...] e engravidei acho que por descuido [...] Nenhum dos dois foi uma coisa planejada, mas foram aceitos de bom coração. Deus sabe o que faz, se Deus mandou era hora" (Uliane).

Assim não planejar a gravidez é algo que está presente na vida da maioria destas mulheres e parece que o planejamento familiar é algo que não faz parte das suas vidas e as histórias de vida apontam que o controle da reprodução é sempre responsabilidade delas.

A ocorrência da gravidez acaba ficando na dependência do "acaso", e dessa forma elas estão expostas ao risco de engravidarem, não observando o intervalo adequado entre as mesmas, colocando sua saúde física em risco.

Entre as mulheres Maria, Leônia, Vitória e Esmeralda foram as que tiveram o maior número de gestações, quase todas elas ocorrendo na adolescência, aumentado a responsabilidade das mesmas, ainda muito jovens, com um grande número de filhos para cuidar, tendo ainda que lidar com condições de vida pouco favoráveis.

"Quando meu filho tava com quatro meses eu engravidei de novo. Aí antes de eu completar 16 anos eu engravidei de novo, no caso com 15 anos. Depois que eu tive o Davi, eu passei só quatro meses evitando porque a minha sogra era muito cristã, dizia que era pecado essa história de tomar medicamento, aí eu fui à onda dela, eu fazia tabela a gente errou quando tava com 4 meses aí eu engravidei do Lucas, do Lucas eu passei 2 anos e seis meses. Aí eu engravidei da Débora, da Débora comecei tomar injeção, mas só que num mês não tinha dinheiro pra comprar, aí foi quando eu o 
peguei, eu não gostava de preservativo. Aí toda hora, é assim, se não tomar remédio num mês eu estou grávida" (Leônia).

"Quando ele tava com sete meses eu já tava grávida da Sara. [...] quando ela nasceu ele tava só com um ano e três meses [...] aí pelos oito meses, oito ou era nove meses eu já tava com um mês de grávida do Gabriel já foi com um ano eu engravidei da Vitória, aí foi assim nascendo um atrás do outro, tudo pequenininho. Jonathan seis anos, vai fazer sete em dezembro, tem a Sara com cinco e o Gabriel tem quatro e a Vitória tem dois e estou grávida de sete meses" (Vitória).

Nessa perspectiva, observamos que a gravidez não planejada aponta para uma desigualdade entre os gêneros. Os parceiros não estão presentes nos relatos como alguém que divida as responsabilidades na reprodução, mostrando uma relação de desigualdade existente entre eles, que os libera da responsabilidade e da prevenção de uma gravidez não desejada, cabendo a elas todas as decisões sobre o que fazer com a gestação e assumir a maternidade.

A primeira e as gravidezes subseqüentes, para a maioria, das mulheres estudadas não foram desejadas, porém assumir a responsabilidade com a gravidez e a maternidade fez parte do cotidiano destas mulheres, que não encontraram métodos seguros de controle da reprodução ou um método eficaz de aborto e não obtiveram a colaboração do parceiro para prevenir esta ocorrência. Mudar este quadro significa uma transformação que seria incluir os homens nos direitos reprodutivos e assim homens e mulheres poderem ter uma relação mais igualitária.

\section{Sentimentos vivenciados com a maternidade}

Sentimento é definido como sendo o ato ou efeito de sentir, estando ligado à sensibilidade, à disposição afetiva em relação às coisas de ordem moral ou intelectual e pode ser descrito como afeto, amor, tristeza, pesar entre outros (FERREIRA, 1993).

As mulheres de nosso estudo que foram mães na adolescência, pelo tempo que vivenciam a maternidade, já têm definido o seu papel materno e pela idade delas já não 
contam mais com a mesma rede de apoio que podem ter tido disponível na primeira gravidez. Observamos nas histórias alguns sentimentos apresentados por elas frente à gravidez e à maternidade. Apesar do desejo que elas apresentaram de ser mães, a vivência da maternidade, em situações tão adversas e após passar o encanto inicial, é ressignificada por várias delas e sentimentos contraditórios são expressos, mostrando a realização do desejo de ser mãe, mas ao mesmo tempo percebendo o ônus que carregam por viverem em condições adversas e em um contexto de vida de exclusão social.

As histórias de vida evidenciam sentimentos de grande insatisfação com o rumo que suas vidas tomaram, de sofrimento, violência e solidão. Este sofrimento está relacionado à falta de afetividade e de apoio a que estas mulheres estão sujeitas, assumindo toda a responsabilidade dos cuidados com os filhos, responsabilidade essa que muitas vezes é um peso em suas vidas. Estes sentimentos mostram a contradição dessas gravidezes, cuja maioria não foram planejada, mas não foram caracterizadas como indesejáveis. Vejamos o que algumas mulheres dizem sobre seus sentimentos:

"Minha vida piorou [...] Porque eu tava noiva ainda, não tinha casado com ele não, eu casei com seis meses de grávida" (Vitória).

"Fiquei meio amarga como dizem as pessoas, sem aquele encanto que era antes, que com qualquer coisa, com qualquer pessoa você se encantava. Você pensa em muitas coisas antes de fazer qualquer coisa e ver como vai ser o futuro" (Isadora).

Mariana nos mostra a confusão de sentimentos que vivencia entre a identificação com a maternidade e o relacionamento difícil com o pai de sua filha. Seu relato aponta para o despreparo na escolha, pois como vimos em dois meses de relacionamento eles já haviam decidido terem um filho e ficarem juntos. Vejamos se relato:

"Mas foi bom porque a gente planejou tudo. Não foi bom. Porque foi mais ruim do que bom. Que eu não o conhecia direito, depois que conheci já era tarde, já tava grávida, sem poder mais voltar atrás. É que eu descobri que ele não era a pessoa que eu pensava que ele fosse, por isso" (Mariana).

A maternidade agora é representada como o sentimento de ter falhado, como um erro pessoal. De acordo com Uliane, a maternidade é responsabilidade da mulher e a sua 
vida ou o seu sofrimento é o pagamento deste erro, mas ela se sente orgulhosa e cuidadosa com seus filhos.

"Esqueço até de mim, mas tudo que eu tenho é pra dar pra eles, porque eles não pediram pra virem ao mundo, então acho injusto eles passarem por dificuldade e por necessidade, e nem pagarem pelos meus erros. Eu acho que eu quero meus filhos só pra mim. Eu trago todinhos pertinho de mim" (Uliane).

Entretanto Taís que rejeitou a sua primeira experiência de maternidade, cujo desejo foi doar o seu primeiro filho, pelo fato de se encontrar sozinha para assumir esta gravidez, aponta a culpa pela falta de cuidado que teve com o mesmo,

“[...] quando ele nasceu eu não queria ele sabe, porque eu não sabia cuidar dele, eu não sabia nem o quê fazer com ele quando ele chegou lá na cama, eu não sabia nem pegar. Ficava só olhando pra ele, ele se mexendo, bichinho. Pronto disse que ia dar a uma mulher, mas como quando eu cheguei em casa, a minha mãe já tava lá, ela disse que não era pra dar, pegou ele pra ela" (Taís).

Entretanto nas gravidezes subseqüentes, na presença de um companheiro tem sentimentos positivos.

Orquídea afirma que era muito jovem quando da sua primeira gravidez e, mediante o sofrimento vivenciado, manifesta o desejo de abandonar o companheiro e inclusive os filhos e ter possibilidades de estar "só paquerando e arrumando namorado". Entretanto o sentimento de afeto que nutre pelos filhos é evidenciado pelo desejo de cuidar dos mesmos.

"Eu me sinto como uma coitada nisso aí sabe, sou muito nova, se fosse por mim eu estava sozinha, só, sozinha mesmo, só paquerando, arrumando namorado não quero casar, quero passar um tempo sozinha, cuidando dos meus filhos só curtindo, aprender o que tem de aprender, aprender mais as coisas da vida porque eu já aprendi muitas coisas com o sofrimento, mas quero aprender mais da vida, não confiar em qualquer um, porque eu confiava muito e 
era pior para mim, era mais decepção, era mais sofrimento ainda" (Orquídea).

A fala de Aparecida é muito contundente e impressionante quando refere que " [...] não vivo eu vegeto [...]". Ela reflete todo o sentimento negativo de ter sido mãe na adolescência dentro de condições socioeconômicas desfavoráveis que a impediram de buscar outras oportunidades, como estudo e trabalho, além de ter se despojado da sua própria identidade. Por outro lado, os filhos aparecem como o centro de suas vidas como podemos observar na narrativa cheia de contradição apresentada a seguir: "Foi ruim, foi péssimo, eu não esperava, empatou minha vida, como eu digo hoje, que eu só vivi até ter a Bárbara, de lá pra cá eu não vivo para mim, vivo para eles" (Aparecida).

A maternidade na adolescência ocorreu no momento em que essas mulheres poderiam estar realizando outros projetos de vida, entretanto o contexto desfavorável de inserção precoce no trabalho doméstico, o desinteresse pelos estudos, o fracasso escolar não favoreceram o desenvolvimento individual delas. Dessa forma, apesar dos sentimentos negativos que apresentam em relação à maternidade não planejada, assumem o papel de mães e esposas, restringindo seu espaço social ao contexto doméstico. Assim a maternidade que, no momento de sua ocorrência, representou sua passagem para uma posição de mulher adulta, responsável, com um papel definido na sociedade em que estão inseridas, na atualidade, representa um obstáculo à mobilidade social, visto que as impede de retornar aos estudos bem como sua inserção no mercado de trabalho.

\section{Reações frente à descoberta da gravidez}

As reações frente à gravidez na adolescência foram as mais diversas, com mudanças nas relações entre as pessoas envolvidas, seja com os familiares ou com os parceiros.

Nos casos em que a gravidez ocorreu para fora da união conjugal, ela foi o motivo que desencadeou a união, com o parceiro "assumindo" o papel que elas esperavam dele, ou seja, que assumissem a responsabilidade de pai. Assim alguns desses homens, na visão das mulheres pesquisadas, desejavam formar uma família e aceitaram a paternidade com naturalidade. 
Outros inicialmente questionaram a paternidade, mas as histórias de vida dessas mulheres apontam que os relacionamentos já se configuravam como duradouros, levando os parceiros a "assumirem" a paternidade e as companheiras.

Salem (2004) relata que, quando acontece uma gravidez inesperada da parceira, os homens tenderão a assumi-la de alguma forma, o que neste grupo que pesquisamos caracterizou-se por meio da coabitação. Bruno e Bailey (1998), em pesquisa, em dois grupos de adolescentes, sobre como a gravidez na adolescência afeta a vida delas, constataram que os parceiros pareceram estar satisfeitos com a gravidez.

É interessante observar, por meio das narrativas das mulheres, que a paternidade fez com que estes homens se mobilizassem em assumir a paternidade, constituindo junto com elas um núcleo familiar. Vários deles, mesmo assumindo a paternidade, em decorrência de condições econômicas desfavoráveis, passaram a coabitar junto com os familiares paternos ou maternos e com o passar do tempo estabeleceram seus próprios lares.

Para Uliane, seu namorado the pareceu mais feliz que ela com a notícia da gravidez. A postura masculina do namorado de Evelin pode ser comparada à afirmativa de Arilha (1999b) de que as mulheres desejam ter filhos e os homens, família. Vejamos alguns relatos delas sobre a atitude do parceiro:

"Aí ele disse: - agora vamos arrumar uma casa pro meu filho, vamos cuidar, pra quando meu filho nascer, ser uma pessoa muito feliz, dar muito carinho a eles, ter muita coisa que nunca eu tive nem você teve" (Evelin).

"[...] falei com meu namorado, eu acho que ele gostou mais do que eu que na hora, pra mim foi um choque, mas ele gostou em hora nenhuma ele disse pra tirar, a gente conversou, conversou com a mãe dele vamos assumir e pronto, até hoje nunca posso dizer que ele foi um mau pai, não, é um ótimo pai, da hora que seus filhos nasceram até hoje não tenho o que queixar dele, sempre foi um ótimo pai, me apoiou, não vou lhe deixar com a criança" (Uliane).

"Eu contei a ele meu esposo, foi a primeira pessoa, ele disse: - será que é meu? Eu disse: - é; aí desse dia pra cá ficou bom comigo a gente ficou junto mesmo" (Tieta). 
Aparecida que tentou abortar e deixou a escola, pois a princípio seu namorado, que também era um adolescente e não devia estar preparado para tal responsabilidade não a "assumiu": "[...] quando eu conversei com ele que tava grávida ele correu, ele tinha 17 anos. Quando eu estava bem perto de tê-la foi que ele apareceu, ai ficamos até hoje”. Mostra-se a importância, para estas mulheres, de não serem mães solteiras neste grupo social e o valor da paternidade.

Para Chodorow (1979), a identificação de gênero masculino, com papel masculino é posicional, ou seja, a identificação com os aspectos masculinos de seu pai e outros homens de tal relação pode ter contribuído para gerar a atitude que eles tomaram, frente à gravidez da namorada, ou seja, de assumir o filho e a mulher, assumindo o "papel de homem" que pode ser o que aquele grupo social esperaria dele.

Esmeralda fala sobre esta atitude, que considera como normal, ou seja, a que se esperaria dele:

"Ele reagiu normal como qualquer adolescente normal. É normal, porque ele não rejeitou o menino. Ficou alegre porque aconteceu que ia ser pai pela primeira vez" e depois ela complementa: "a mãe dele disse: - tem que assumir, sempre quem mexe com as filhas dos outros tem que assumir" (Esmeralda).

De acordo com Bozon (1998), as atitudes masculinas e femininas frente à sexualidade podem ser vistas sob os aspectos de gênero e expressam uma maneira de dominação social masculina. Esta atitude dos homens de se unirem às suas namoradas grávidas pode ser uma forma de representar esta dominação, e este comportamento masculino pode estar ligado a sua própria experiência e trajetória, da construção de sua identidade.

Arilha (1999), em pesquisa realizada com homens, verificou que para eles a decisão sobre a vida reprodutiva era coordenada pelas mulheres e, muitas vezes, acabavam sendo obrigados a modificar o rumo de suas vidas, porque aceitaram a posição das mulheres neste processo. No caso de Leônia, a sugestão para que engravidasse partiu de seu namorado frente ao sofrimento que ela vivenciava.

"Quando a gente começou a namorar, ele tinha 19 anos, quando viu meu sofrimento que era com minha mãe, meu pai, vivia num canto 
e no outro, aí ele disse que se eu engravidasse dele me botava dentro de casa. Aí eu apareci grávida, a gente não se prevenia, eu disse e ele foi logo agindo, botando, fazendo o que tinha de fazer dentro de casa, aí eu fui morar com ele. [...] ele por ser homem, dizia que não era aquela pessoa de sair com a pessoa e deixar, ele disse que as outras ele deixava porque já eram de outro e ele não tinha compromisso de criar filho e assumir [...] ele garantiu que ia me assumir e eu apareci grávida e ele aceitou, foi uma boa hora assim de ajeitar nossa casinha e morarmos juntos" (Leônia).

As trajetórias conjugais do grupo estudado seguem um padrão esperado pelos padrões sociais mais tradicionais e, mesmo que as histórias de vida das mulheres mostrarem que elas não vivenciarão atitudes preconceituosas, a maternidade precoce, o desfecho apontou que as mesmas conseguiram estabelecer uma relação estável com seu companheiro e filhos.

A reação da família frente à descoberta da gravidez, segundo Catharino e Giffin (2002, p.10), pode ser dividida em dois momentos, num primeiro ela se "surpreende e condena a adolescente", depois a mãe se torna uma aliada e ajuda a interceder junto ao pai e namorado. Porém até que isto ocorra, "a adolescente vive de forma dolorosa as represálias e críticas de alguns membros da família, da escola e da comunidade [...]”’.

Nas narrativas das mulheres de nossa pesquisa, as famílias apresentaram reações variadas, que perpassam por atitudes de não-aceitação representadas por medidas radicais de abandono das filhas, colocando-as fora de casa, fato que se passou com Maria e Uliane a reações de choro, susto e aceitação com demonstração de alegria. A maioria das famílias, apesar de não se querer a gravidez da filha, na medida das possibilidades de cada uma deu apoio às filhas, conforme contaram a esse respeito:

"Primeiro ela me colocou pra fora, passei um mês com a minha irmã, deram muito conselho a ela aí voltei pra casa, minha mãe é um pouquinho, meio brutazinha, nunca é de chegar, sentar, não chama pra conversar, não entra num acordo é tudo na ignorância. Minha mãe dizia: - Ah! Você com 15 anos com um filho, não tinha precisão, devia ter ele com a idade já avançada de pegar filho, não com 15 anos, que adianta ter um filho com 15 anos [...]" (Maria). 
"Quando ela soube que eu estava grávida a primeira coisa que fez foi me botar para fora. [...] eu fui pra casa do meu namorado, dormi lá. No outro dia fui pra casa da minha madrinha [...] foi ela que me ajudou fiquei na casa dela, ela cuidou de mim os nove meses, arrumou pra eu ir pro médico e tudo, minha mãe só falou comigo no dia que eu estava sentindo as dores dentro de casa, depois dos nove meses foi que ela veio falar comigo"(Uliane).

“[...] eu disse a minha mãe ela chorou muito, eu também chorei com medo dela bater em mim, dela brigar, mais ela não brigou comigo, só fez me dar conselho, disse: - por que você não me disse; eu não disse porque eu tinha muito medo dela dar em mim, dela não aceitar, mas ela aceitou minha gravidez, não empatou não" (Tieta).

As mães das adolescentes se mostraram como a figura central no processo de aceitação ou rejeição da gravidez, tomando para si a responsabilidade pela expulsão e retorno da filhas ao lar. As reações que as mães apresentaram frente à gravidez foram fundamentais no curso da gravidez vivenciada pelas adolescentes. $\mathrm{O}$ pai, que é descrito como uma figura mais distante no cotidiano dessas mulheres, aparece pouco nas suas narrativas em aspectos referentes à sua reação frente ao conhecimento da gravidez. Aquelas que relataram sua reação a caracterizaram como de indiferença ou de nãoaceitação, havendo mudança no relacionamento entre ambos.

"A minha mãe aceitou bem, mas o meu pai não aceitou de jeito nenhum, porque ele não queria que eu vivesse com ele, nem que engravidasse porque no fim ele dizia que ia acabar sendo um sofrimento para mim" (Leônia).

"Acho que a minha mãe ficou meio assustada, ela não acreditava. Meu pai não morava aqui, morava em Santana com outra mulher e com quatro filhos. E quando o Jonathan nasceu, ele nem sabia que eu tinha casado grávida" (Vitória).

Para Isadora, a gravidez prejudicou a relação que ela tinha com o pai, ela nos conta 
“[...] eu passei uns três quatro anos sem falar com ele, justamente porque ele não aceitava minha gravidez. Aceitava na medida do possível porque não era aquilo que ele queria pra mim, mas como ele disse que eu não era a primeira e nem iria ser a única no mundo. Mas a gente ficou com a relação meio ruim" (Isadora).

Vera aponta a importância de já estar unida com o pai de seu filho como um fator positivo para a reação das famílias frente à gravidez, "As duas famílias aceitaram, tanto a minha como a dele, minha família só não aceitaria, se ele fosse separado. Por exemplo, se eu ficasse grávida e sozinha tomando conta da criança".

Apesar de a maioria das mulheres terem contado com o apoio das mães quando tomaram conhecimento da gravidez, elas se ressentem da falta de diálogo sobre sexualidade com as mães, apontando uma relação distante entre elas, ou a dificuldade de se discutir/assumir a sexualidade de suas filhas.

"Se a minha mãe tivesse conversado comigo, me explicado, nem eu, nem a minha irmã tinha engravidado tão cedo, tinha se cuidado, mas ela nunca conversou comigo sobre isso. Nem ela explicava e eu tinha vergonha, não tinha ninguém que conversasse. Mas ela não fechou a porta na minha cara, ela falou, reclamou mas me deu todo apoio, ela disse o que pudesse fazer por mim ela fazia e como fez" (Aparecida)

Segundo Dias, Oliveira e Gomes (1997), em pesquisa com jovens grávidas atendidas em um Hospital Público de Porto Alegre, as reações dos familiares à gravidez foram dramáticas no primeiro instante em que tomaram conhecimento, depois melhoraram frente a uma aproximação emocional dos pais, mais especificamente da mãe.

Em nossa pesquisa, encontramos entre as mães reações carregadas de muitas emoções em relação à jovem grávida. A princípio as reações refletem os próprios conflitos em que estas famílias vivem, com famílias reconstruídas, em dificuldades socioeconômicas, com pouca afetividade e diálogo.

Podemos observar que cada família apresenta uma forma de reagir e lidar com a gravidez de sua filha adolescente, as narrativas nos apontam que a maioria não queria que suas filhas trilhassem pelo caminho da maternidade na adolescência. As reações de 
expulsão de casa, choro, susto representaram como essas famílias reagiram a uma situação inesperada e não desejada. Os sentimentos contraditórios permeiam a reação das famílias, visto que era do conhecimento das mesmas que os adolescentes viviam relacionamentos afetivos, porém elas não foram informadas e orientadas sobre como viver a sua sexualidade com segurança e autonomia.

\subsubsection{CONSEQÜÊNCIAS DA MATERNIDADE NA ADOLESCÊNCIA}

\section{Infidelidade masculina, violência e separação do parceiro}

Badinter (1993) afirma que a transformação do mundo traz à tona as diferenças da masculinidade, sobretudo agora que, em nossos países, vemos como o poder que lhes servia de proteção desmorona. Sem suas defesas milenares, o homem expõe abertamente suas feridas. A autora faz uma análise da literatura européia e americana de quinze anos e da visibilidade a uma gama de sentimentos que lhes acercam: "a raiva, a angústia, o medo das mulheres, a impotência, a perda de referências, o ódio de si mesmo e aos demais, etc." $(\mathrm{p} .53)^{4}$.

As mulheres queixam-se de sua falta de liberdade e se ressentem da atitude do parceiro, que as trai e as agride e elas se vêem, muitas vezes, impossibilitadas para reagir e modificar a situação. Badinter (2004, p.27) afirma que a dominação masculina baseia-se no poder dos homens em tratar as mulheres como objetos sexuais. "Este poder, que se faz retornar a origem da espécie, se havia iniciado com a violação".

De acordo com Salem (2004), a sexualidade masculina pode ser representada em termos de uma teoria sexual pulsional, tendo em vista o desejo incontrolável que o homem tem de transar, ligado à "vontade" de fazer sexo. Segundo a autora, a traição masculina prevê simultaneidade de vínculos com diferentes parceiras, fato creditado "à difículdade masculina de resistir aos apelos das numerosas [...] parceiras sexuais que afirmam haver tido ao longo da vida" (SALEM, 2004, p. 28).

\footnotetext{
${ }^{4}$ Tradução da pesquisadora
} 
De acordo com a autora, “a quase vocação masculina para a 'traição' é justificada ora com base na 'vontade' sexual incontrolável, ora no descompasso, também naturalmente fundado, entre suas 'necessidades' sexuais e as da parceira fixa" (SALEM, 2004, p.28). As explicações têm se fundamentado na naturalização dessa condição apontando que o homem trai impulsionado por essa pulsão sexual que subjuga-o a responder aos sinais do seu corpo, justificando-se com o argumento de que a 'carne é fraca'. A traição da mulher, entretanto é vista como um ato de "intencionalidade, de um ato de vontade deliberado e controlável" (SALEM, 2004, p.28), portanto condenável.

Assim, socialmente, temos um duplo padrão de moralidade e normas para a (in)fidelidade, os homens podem trair, porém suas mulheres não podem trair e baseado nessas concepções é que parece residir a aceitação ou resignação que algumas mulheres demonstraram ao relatar a traição de seus companheiros.

Apesar de Bozon (1998) reconhecer que as trajetórias conjugais atualmente vêm sofrendo modificações ao longo da história e que existem modificações no papel da mulher com uma esperada modificação de sua sexualidade, não parece ser isso que observamos entre estas jovens mulheres que estudamos, que ainda mantêm um padrão em que o homem exerce um papel mais autônomo no exercício de sua sexualidade e a mulher se subordina a essa conduta masculina reconhecida como parte de sua natureza. Entretanto observamos que, ao se subordinarem a essa situação, não significa que elas a aceitem como natural, mas em suas narrativas demonstram a impossibilidade de agir devido à dependência econômica que têm dos mesmos.

"Na $2^{\mathrm{a}}$ gravidez, sempre ele tinha as andada dele fora de casa à noite, quando foi depois ele contou que tava com um caso com outra pessoa. A minha reação foi mudar muito com ele, por causa dele, uma pessoa que tem compromisso não podia fazer isso. Porque se o homem tem a sua mulher em casa não devia arrumar outra fora, principalmente quando a gente não convive na casa da gente mesmo [...] Quando eu falava, ele reagia com muita ignorância, queria ser maior que eu, mas pela vontade dele mesmo, depois que ele ficou mais velho um pouco aí ele parou de fazer isso" (Esmeralda). 
Bonzon (1998) admite que os comportamentos e as experiências de homens e mulheres no que se refere à sexualidade configuram-se como uma das maneiras de dominação de um sobre o outro. A infidelidade, de uma certa forma, pode representar subjugação da mulher entre essas mulheres, visto que para muitas delas uma separação poderia significar a perda das condições mínimas em que vivem.

Sobre a o papel masculino na relação sexual, Foucault (2001b) afirma que ao homem cabe a função ativa e a mulher fica com o papel passivo de receptora nesta relação, sendo dados valores e funções distintos sobre quem exerce o papel de domínio nesta relação e a quem cabe ser dominado. A traição e a agressão, muitas vezes, parecem ser a forma como os homens exercem essa relação de dominação, enfatizando a sua liberdade no exercício da sua sexualidade e não aceitando oposição à mesma, subordinando a mulher a sua conduta sem que a mesma reaja de uma maneira mais efetiva, apesar da revolta contra a situação a que é submetida pelo companheiro.

A violência contra a mulher ganhou visibilidade na década de 1980, através da luta feminista, seguida posteriormente por intervenções no âmbito legal e judiciário. A maioria das denúncias de agressões ocorre dentro das relações conjugais (GREGORI, 1999).

Entre as mulheres estudadas, existe uma dualidade na interpretação da violência o que pode ser visto a partir da narrativa que Esmeralda faz do comportamento de seu parceiro “[...] ele não é uma pessoa agressiva comigo. Ele é um pouco grosso [...] porque sempre que ele bebe fica muito enjoado, não tem muita paciência, é só este o problema dele”.

Aparecida não aceita agressão e procura revidar,

"Como mulher eu gosto muito da minha casa, do meu marido, agora ultimamente passei por um sufoco muito grande, tô passando que meu marido agora se enganchou com outra na rua, tira do pouco que a gente tem para dar a essa da rua [...] Quando ele está bom ele é uma pessoa, mas quando bebe! Aí dana-se a ficar bravo comigo, querendo quebrar as coisas, eu também não deixo, não vou deixar ele quebrar as coisas, ele vem dar em mim, eu vou e dou nele também" (Aparecida).

Caroline relaciona a agressão com o álcool, 
"Ele chegou em casa tarde, bêbado, aí a gente brigou, discutiu, aí os vizinhos vieram tirar a briga da gente. [...] É horrível, a fase mais ruim da minha vida eu acho, porque ser traída como eu já fui dentro de casa mesmo, quando deixava uma pegava outra. Ele chegou até namorar de porta com uma menina, ia noivar e tudo e eu aqui sem saber não, nas minhas gravidez ele tava me traindo aí foi a fase mais difícil, pra mim a traição é a pior coisa do mundo. Foi o momento mais horrível. [...] ele já bateu em mim três vezes quando tava bêbado" (Caroline).

A violência conjugal a que essas mulheres estão submetidas está relacionada ao uso abusivo de álcool e à traição, comportamentos socialmente permissivos ao homem, e contra os quais as mulheres não encontram apoio para lutar contra eles.

A violência doméstica, entre esses casais, muitas vezes, caracterizou-se com lesões corporais, porém nenhuma delas fez qualquer denúncia na justiça contra seus parceiros, demonstrando comportamentos passivos e esperando que estas agressões parassem naturalmente, o que demonstra que as relações têm se baseado nas assimetrias de gênero, quando identificamos a passividade com que elas reagem à agressão.

Gregori (1999), analisando denúncias em delegacias de mulheres, verifica que elas não estavam interessadas em punir ou processar seus parceiros, mas sim serem ressarcidas pelas perdas morais ou materiais e principalmente esperavam que seus maridos deixassem de agredi-las.

Para a autora, esses relacionamentos violentos "revelam com intensidade que a agressão funciona como uma espécie de ato de comunicação, nos quais diferentes matizes podem estar atuando" (p.64). Ela continua afirmando que estas relações "evidenciam, sobretudo, que o problema principal das questões de gênero está na assimetria entre as partes" (64).

A violência doméstica relatada pelas mulheres do estudo demonstra a existência de relacionamentos conflitivos vividos por elas, com agressões físicas e verbais freqüentes, para as quais elas não buscam ajuda externa, mas as deixam revoltadas, como afirma Orquídea: 
"Já apanhei devido a ter sido traída, não tem condições de uma mulher ainda amar um homem, ela pode gostar porque é pai dos filhos, mesmo sendo pai dos filhos não tem condição, esta semana tive uma briga muito feia com ele. Um pai de família que só entra em casa para brigar [...] eu fiquei muito revoltada, tive vontade de sair de noite, deixar casa, deixar filho, deixar tudo para ele [...]" (Orquídea).

A vida delas é permeada de muito sofrimento sem muitas alternativas de melhora, e as traições e agressões têm se caracterizado como forma de dominação masculina que se configura, nesse grupo, e se mantém porque as mulheres estão confinadas ao espaço doméstico, não visualizando alternativa para sair dessa situação. Segundo Gregori (1999), ser mãe impõe responsabilidades que “[...] altera a configuração de papéis sexuais e as posições de masculinidade e de feminilidade no interior de um casal" (58). Coabitar é uma situação propícia para o surgimento de conflitos que nem todos os casais têm condições de resolver de maneira amigável e madura.

A maioria destas uniões surgiu da necessidade de dar um caráter de aceitabilidade social às gravidezes não planejadas pelo casal e, com o passar dos anos, os homens passam a questionar as que lhes tiraram a liberdade e aumentaram sua carga de responsabilidades frente à sobrevivência de sua família. Em meio a grandes adversidades e não encontrando apoio social para lidar com essas situações, encontram na traição uma forma de fugir das responsabilidades do cotidiano, mesmo que tenha conseqüências para o relacionamento.

A separação em alguns casos foi a alternativa de opção para solução dos conflitos, como nos mostram as histórias de vida. A decisão por uma separação, na maioria dos casos, foi tomada pela mulher, mostrando sua capacidade de sair de situações que não mais satisfazem a suas necessidades afetivas, enfrentando o ônus da sua resolução. No caso de Uliane e Maria, esta decisão foi tomada considerando sua insatisfação com a situação vivida. A seguir, vemos o que elas nos contaram sobre a separação:

“Ah! Eu sou separada, porque não dava mais, não gostava de viver só por causa da filha, não adianta, quando ele bebia queria vim pra cima de mim, [...] a gente brigava bastante, se tiver acordo quero fazer acordo ele bota tudo difícil. Falta uma coisa, estou precisando disso dentro de casa, arrumo aí bota sufoco que não dá pra 
comprar, fui me abusando, quero mais não, num dá mais não. Só nós dois dentro de casa, ele ia trabalhar eu ficava sozinha em casa sem uma companhia. Ele quer voltar, fico pensando se volto, estou indecisa ainda se aceito ou não" (Maria).

"A gente ficou oito anos juntos, separamos agora há pouco, no Natal. [...]. Hoje em dia eu estou separada, arcando com as conseqüências. [...] Acho que estou aprendendo a encarar a vida, lutando pra conseguir e tenho fé em Deus que eu vou conseguir. [...] estou encarando a vida como ela é, de frente sem medo de ser feliz, sem medo de encarar. [...] se for pra viver sozinha mesmo tendo só essa preocupação e dificuldade, a viver ao lado de um homem e não ter sossego, nem a paz, eu prefiro ficar só, porque não adianta nada você morar com uma pessoa só por bens materiais e você não ter a sua paz. Eu pelo menos me preocupo com as coisas dentro de casa, mas eu tenho a minha paz, tenho o meu sossego, graças a Deus to vivendo bem" (Uliane).

Outras mulheres narram a vontade que têm de se separar de seus parceiros, mas não encontram condições propícias para isso. Como Aparecida nos conta:

"Que nem eu falo para ele, eu disse a ele, se ele não melhorar eu vou viver a minha vida; e ele vai viver a dele. Ele disse que eu com três filhos eu não posso viver como uma pessoa normal. Posso. Só trabalhar e arrumar uma pessoa pra deixar meus filhos. Minha vida não é boa por causa disso, mas que eu vejo tantas mães que têm cinco e seis filhos e vive bem" (Aparecida).

Isadora decidiu se separar porque queria sua liberdade de volta, pois percebeu que a maternidade a fez abdicar de coisas de que ela gostava e das quais sentia falta

“[...] na minha primeira gravidez ele sempre esteve comigo. A gente ainda viveu três anos, aí quando eu engravidei do menino, eu resolvi me separar, deixei ele onde a gente morava, que a gente morava no interior. Aí eu fui embora, vim embora pra casa da minha mãe e não quis mais saber. Eu estava cansada de todo 
mundo poder se divertir e eu sempre ficar ali em casa, eu não tava agüentando mais aquela situação de tá ali naquele lugar, longe da minha família, aí resolvi vir embora" (Isadora).

Separação e reconciliação também foram vividas por Mariana, Vitória e Tieta e uma das razões apontadas é que os filhos permaneçam em contato com os pais, fato que pode ser utilizado para mascarar a dependência que têm do companheiro, tanto financeira, pois a mesma não trabalha, como afetiva.

"E até hoje estamos juntos e não pretendo me separar mais, pois tenho minhas duas filhas pra tomar conta". Vitória, "Uma vez ele foi embora, ele se separou passou uma semana e voltou pra casa $[\ldots] "$ (Tieta).

Nenhuma separação ocorreu motivada pela infidelidade feminina ao contrário do que aconteceu em relação à masculina. Vale ressaltar que as mulheres, às vezes, ainda se responsabilizam pelo insucesso da relação e se sentem culpadas por não ter tido competência para manter a relação como é o caso de Lêonia:

"[...] logo no começo foi bom, foi muito amor, eu gostava muito dele, mas depois eu fui desgostando assim com a traição do marido, foi aparecendo o que não devia, mulher pra ele, ele foi começando a sair de casa eu fui desconfiando dele, não acreditava mais nele, no que ele me dizia e infelizmente apareceu outra pessoa pra cuidar dele, que foi mais sabida do que eu e conseguiu ter ele, e ainda vive com ele, hoje está grávida dele [...]" (Lêonia).

Essa situação caracteriza as assimetrias de gênero que permeiam as relações conjugais, no grupo estudado, e dá visibilidade à posição de submissão a que essas mulheres estão sujeitas, determinadas por questões sociais, culturais e predominantemente econômicas. Essa relação de dominação masculina evidencia o poder exercido nas relações entre os sexos, visto que aos homens é dado o direito de trair e praticar atos violentos sem que isso acarrete em ônus para os mesmos. Um agravante, nessa condição, é que às mulheres resta conviver com a frustração do fracasso conjugal além do ônus da educação dos filhos e da provisão básica para os mesmos, tendo que retornar para suas famílias de 
origem, visto que a maioria se encontra fora do mercado de trabalho, condição agravada pela falta de qualificação profisssional.

\section{A dependência do companheiro}

Wagner et al. (2002) afirmam que apesar das mudanças que vêm ocorrendo quanto às funções parentais na família, permanecem ainda estabelecidas algumas atribuições vinculadas às questões de gênero, como por exemplo, a mãe cuidar dos filhos e o pai é responsável por prover o sustento familiar. Isso é confirmado por Bruschini (1999, p.25), quando afirma que independente destas mudanças ainda hoje cabe à mulher "sobretudo as atividades reprodutivas e os cuidados com a casa e os membros da família, enquanto aos homens cabe o papel de provedor desse grupo", tendo conseqüências diferentes sobre um e outro sexo, na sua participação no mercado de trabalho.

As histórias das mulheres de nossa pesquisa corroboram com as afirmativas dos autores acima. Observamos que o parceiro é o provedor da família, eles estão inseridos no mercado de trabalho formal ou informal e apenas Isadora, que se encontra separada do pai de seus filhos não recebe ajuda do mesmo para a manutenção dos filhos "[...] não me ajuda em nada". Ela exerce atividade remunerada fora de casa e recebe apoio de sua mãe.

As mulheres estudadas reconhecem seus parceiros como trabalhadores e valorizamnos, apesar de considerá-los subempregados e compreendem que são explorados e têm dificuldade de prover com dignidade as necessidades de suas famílias.

"Só ele trabalha eu faço dívida, faço feira e é ele quem paga tudo. [...] ele é muito explorado, trabalha muito e o patrão dele não quer dar mais do que ele ganha, é um sofredor sabe, é trabalhador [...]" (Orquídea).

Identificamos na narrativa de Carolina a dificuldade que tem de sobreviver e de alimentar seus filhos apenas com o salário do parceiro,

"Meu marido trabalha no mercadinho de balconista, ganha um salário, mesmo assim não dá, porque com $\mathrm{R} \$ 80,00$ paga água, que energia não dá, tem que dar alimentação pra ela, já colocou ela no leite novamente porque ela tá desnutrida" (Carolina). 
O mesmo acontece com Esmeralda,

"[...] só acho difícil porque ele tem dificuldade pra compra alimento que são muitas crianças, aí fica mais difícil pra ele que ganha salário, fica difícil cuidar de quatro crianças, ainda sendo todas pequenas" (Esmeralda).

Mesmo no caso de Maria, Uliane, Leônia e Mariana que vivenciaram o rompimento conjugal, elas recebem ajuda financeira para seu(s) filho(s), mas que não é suficiente para garantir o sustento da família. Em estudo realizado por Santos (2001), a família é a provedora de suas filhas "algumas dessas mães [...] juntamente com seu(s) filho(s) vivem totalmente na dependência de seus pais, particularmente de suas mães ou se viram como podem, sozinhas" (p.107), o que não ocorreu com as mulheres deste estudo.

“O pai delas dá o dinheiro todo mês, toda quinzena o pai dela dá das duas, mas não dá pra comprar tudo, sempre fica faltando. Aí pronto tem que esperar por ele, pra ele dá. Minha mãe também ajuda. Assim é difícil [...]” (Maria).

A fala de Uliane nos mostra que essa dependência pode ser usada pelo parceiro como um fator de negociação para voltarem a viver juntos,

"[...] o pai arca com a responsabilidade dele que tem que dar, mas o restante que uma certa quantia não dá pra arcar com uma casa [...] Às vezes o pai dele diz, vamos voltar a vida de mulher morando sozinha é muito difícil [...]" (Uliane).

Destaca-se nas histórias de vida dessas mulheres que a autonomia financeira dos parceiros dá a eles mais liberdade para uma convivência social fora do espaço doméstico, fato que não ocorreu com as mulheres, devido a esta dependência e ao cuidado com os filhos, a casa e o próprio parceiro, como relatado por Aparecida

"Mas também ele vive a vida dele mais do que eu vivo a minha, porque ele trabalha recebe seu dinheiro, sai, se diverte com os colegas dele e eu dentro de casa [...] Ele não é homem de sair com a mulher pra se divertir, só sai só" (Aparecida).

Este foi um dos motivos da separação de Uliane e Taís 
“[...] a gente veio pra se deixar foi que ultimamente ele saía pra trabalhar, chegava no outro dia, pra beber e farra e esquecia da família, é então quer viver a vida de solteiro então você vai ter sua vida de solteiro $[\ldots]$ ". (Uliane).

"[...] ele ficou parado, a gente tava pra se separar. Por causa da dificuldade, ele só pensava em brincar, jogar 'chimbra' [...]” (Taís).

Essas situações vividas por eles corroboram com a afirmativa de Brandão (2004, p. 77), em que os rapazes insistem em manter suas vidas anteriores, tendo dificuldade de reduzir as saídas noturnas com os amigos entre outras atividades que realizavam. Eles têm dificuldade de "[...] dar apoio para corresponder às expectativas das namoradas, no sentido de dividir os cuidados domésticos e as decisões relativas aos filhos".

Leônia revela que quer trabalhar, pois percebe que a dependência que tem do exparceiro pode impedi-la de reorganizar sua vida e buscar uma nova união,

"[...] se eu ficar dependendo dele é um jeito pra eu não arrumar ninguém, não me adianta arrumar uma pessoa pra me ajudar, quem paga o aluguel é ele, quem paga a água é ele, energia é ele, como do que ele me dá, e eu dependendo do meu dinheiro eu não vou tá pedindo as coisas a ele, aí vai ver que eu estou dependente de mim mesmo que eu vou mandar na minha vida" (Leônia).

Encontramos aqui uma questão de gênero bem definida, o homem assume o papel de provedor com uma vida pública e a mulher de sua dependente, ficando sobre sua responsabilidade a vida doméstica limitada ao cuidado da casa, dos filhos e do parceiro. Elas se ressentem desta situação, ao mesmo tempo percebem que o parceiro não tem condições de suprir todas as necessidades da família, e elas não têm qualificação adequada que lhes ajudem a conseguir um trabalho, e associado a isso a comunidade não tem uma rede de apoio, como creches e pré-escola, onde elas pudessem deixar os filhos em segurança para poder trabalhar.

\section{O cuidado dos filhos}


Madeira e Tsunechiro (2003, p. 75), num estudo com mães adolescentes, afirmam que o cuidar "entrelaça-se ao prazer, um complementa o outro. Essa relação simbiótica possibilita às adolescentes cuidar dos filhos com desprendimento, com amor, em uma entrega total".

Em nosso estudo, as narrativas das mulheres revelam os cuidados com os filhos como o fato mais importante de suas vidas atualmente, assim como o cuidado da casa e do marido. Entretanto afirmam que para viverem nessa condição restrita ao doméstico, elas mencionam que tiveram que abdicar de estudar, trabalhar, divertir-se em função dos cuidados e responsabilidades que têm como mãe e esposa.

Esta investigação apresenta facetas do processo de maternidade vividos por elas, que em alguns casos mostram que a realização pessoal delas se deu através do exercício da maternidade. Observamos no relato de Evelin que a sua vida parece girar em torno do cuidado à sua filha - "[...] criança dá trabalho, mais a gente tem que aprender a cuidar, a ter cuidado sempre, precisa cuidar, conversar".

Outras revelaram todos os cuidados e preocupações que têm com seu(s) filho(s). Entretanto manifestam a satisfação que têm nesse cuidado além de os filhos passarem a ocupar um espaço afetivo em suas vidas, amenizando seu sentimento de solidão.

Evelin descreve o quanto é bom cuidar da filha "Eu acho bom, tomar conta de criança, ter paciência, você sabendo levar, sabendo cuidar, sabendo ter carinho com as crianças, com os filho [...]”, ou como não se vêem saindo sem a companhia deles, como relata Mariana "Ela é minha única companhia, pois quando quero sair saio com ela, não sinto falta de ninguém só se for da minha mãe e da minha irmã, mais de namorado não".

A aceitação passiva e substitutiva das suas próprias aspirações em função dos filhos pode ter origem nos seus processos de socialização, quando precocemente foram inseridas no trabalho doméstico, assumindo as responsabilidades dos cuidados dos filhos e das casas de seus empregadores.

Santos (2001, p. 114 afirma que "[...] tratar-se de mulheres centradas em seus filhos e na vida doméstica [...] padrões tradicionais frente à função da mulher na sociedade", sendo, responsável pela reprodução além de cuidar dos filhos, do parceiro e da casa.

Tieta nos mostra a centralidade que os filhos têm em sua vida e o cuidar como um ato contínuo que lhe limita, a faz renunciar a atividades sociais e mais uma vez vemos a falta de uma rede de apoio, 
"Se as minhas filhas não forem comigo eu também não vou. Minha mãe também, não fica com elas pra eu andar. Aí pra onde eu saio tenho que levar elas. Nem todo canto a gente tem que levar criança, aí eu não vou, fico em casa aí mudou tudo, tudo. Eu deixei muitas amizades minhas; eu não deixei por causa das minhas filhas, porque as minhas filhas não empatam nada" (Tieta).

As histórias apontam ainda que os parceiros não foram mencionados quanto à responsabilidade ou ao exercício dos cuidados com os filhos, o que nos faz supor que, neste grupo de mulheres, a presença paterna junto aos filhos e aos cuidados para com estes é ínfima e uma das razões pode estar ligada ao tempo disponível e ao trabalho fora de casa.

Para Arilha (1999b), apesar de geneticamente homens e mulheres contribuírem igualmente na reprodução, o volume de trabalho corporal que ela acarreta para cada um dos sexos não é igualitário. Pelos relatos observamos que este cuidado é de maior responsabilidade da mulher, e em função dessa assunção a maternidade indica mudanças nas suas vidas além da perda da liberdade para um contato social mais intenso. Isso traz conseqüências para estas jovens que se vêem presas dentro deste núcleo familiar, mas se acomodam nessa condição, entretanto não culpam a maternidade precoce por isso, como vemos no depoimento de Esmeralda "[...] é muita responsabilidade porque criança dá muito trabalho [...]".

"Mudou tudo na minha vida, porque eu deixei de sair, só saio se for com ele. Ele não é uma pessoa que goste de sair, não é uma pessoa de andar, só não gosta de andar comigo e eu não sou dessas mães que deixa minhas filhas só pra ir andar, pra ir curtir" (Tieta).

De uma maneira geral, as mulheres referem-se a mudanças que ocorreram em suas vidas com a vinda dos filhos ao fato de a responsabilidade do cuidado dos filhos ficarem com as mães e as opções que são obrigadas a fazer. Leônia optou pelos cuidados dos filhos, pois considerava uma carga muito pesada trabalhar e estudar,

"[...] eu mesmo achava pesado de trabalhar, estudar e tomar conta de filho, aí eu preferi mesmo tomar conta de casa, tomar conta dos meus filhos, mas ainda hoje eu sinto vontade de estudar, eu tava 
pensando em estudar já agora, aí apareceu esse novinho não posso mais estudar" (Leônia).

Para Isadora, a maternidade trouxe mudanças e responsabilidade, ao mesmo tempo em que fala com conformismo com a situação em que vive,

"[...] foi uma barra no começo porque eu não tinha experiência com nada, só com a família, ajudar, minha tia a cuidar do filho dela, mas a pessoa com filho é diferente, porque você é que tem que cuidar, passar o dia todo. Ter aquela responsabilidade. Hoje em dia, às vezes quando a gente fica triste num canto, pensa que podia ter aproveitado a juventude mais um pouquinho. Meus filhos já estão grandes e agora eu tenho que enfrentar o resto. Atrapalhou em algumas coisas, mas tem que ser assim" (Isadora).

Vera, também, faz referência ao peso que o cuidar dos filhos impõe, e expressa a falta de preparo que tinha para ser mãe, além das preocupações geradas pela difícil situação econômica em que vive.

"Pensava que ser mãe não era ter muito trabalho com a criança, principalmente doente. Com uma doença a mãe se preocupa, para ver se tem remédio, às vezes a pessoa também não tem condições para sustentar a criança porque custa muito, tudo isso" (Vera).

Esmeralda, também, expõe sua preocupação com a doença dos filhos, fala da responsabilidade que traz uma criança, deixando transparecer que a maior responsabilidade do cuidado com os filhos cabe à mãe.

"[...] é muita responsabilidade porque criança dá muito trabalho, tem que ter muito cuidado, principalmente em caso de doença, porque criança brinca muito, aí qualquer coisinha fica doente, aí já é uma coisa pesada pros pais que não têm muitas condições, é o caso de ter muita responsabilidade mesmo. A responsabilidade é maior da mãe. Porque a mãe fica mais preocupada, tem mais trabalho de tá no médico com eles. Quem fica responsável é ela" (Esmeralda). 
Observamos que a preocupação com os filhos se reflete na prática, pois nos deparamos com crianças bem-cuidadas e quando isso não aconteceu como no caso dos filhos de Vera que estavam com escabiose, a mãe referiu-se a este fato com preocupação e tinha buscado atendimento na unidade de saúde para solução do problema. Em relação ao filho de Caroline que estava inscrito no programa de recebimento de alimento por estar desnutrido, também é referido como motivo de preocupação devido à situação econômica vivida pela família. Preocupação essa que, no caso de Aparecida, a impedia de desmamar seu filho por não ter a garantia de prover alimento suficiente que substituísse o leite materno, revelando seu medo de que com o desmame seu filho sentisse ou passasse fome. Ela complementa a sua fala sobre o cuidado dos filhos, mostrando um esforço pessoal para que eles sempre estejam bem e não fiquem doentes,

“Como mãe eu me esforço na medida do possível, meus filhos nunca ficam doentes por eu não ligar, eu procuro dar o melhor de mim a eles, pode ser que eles não me agradeçam, mas o que eu posso fazer como mãe eu faço" (Aparecida).

A realidade apresentada por estas mulheres parece estar de acordo com a afirmativa de p. 225) que discute o amor materno como sendo um sentimento que se desenvolve segundo as variações socioeconômicas e históricas, afirmando que estas mulheres “[...] nada têm afora uma vida conjugal difícil, muitas vezes cruel, a maternidade é a grande ocupação de sua vida". Essa realidade é complementada com o que ela afirma que foi visível na história de algumas mulheres em que, de alguma forma, "recusam qualquer contracepção, porque o filho preenche uma carência afetiva e social e compensa, por algum tempo, diversas frustrações" (BADINTER, 1985, p. 225).

Taís fala do cuidar dos filhos, do marido e da casa como sua principal fonte de prazer e satisfação, mas também que traz um sentimento de solidão e ausência de outras possibilidades.

"O que tem de engraçado é que eu cuido dos meus filhos, cuido do meu marido, cuido de casa, às vezes eu fíco aí mais a minha comadre, com a madrinha dele conversando a gente ri. E o que tem de ruim é que eu não vejo a minha mãe, num viajo, não saio pra lugar nenhum. Agora a minha vida como mãe tá ótima, porque eu 
cuido dos meus filhos, que é uma beleza, e da casa sozinha [...]" (Taís).

Os relatos das mulheres, também, estão em conformidade com Rosalvo (1979) que coloca que "as mulheres são absorvidas principalmente em atividades domésticas devido ao seu papel de mãe" (p.40) e a autora continua com a seguinte afirmação "suas atividades econômicas e políticas são restringidas pelas responsabilidades nos cuidados com os filhos e o enfoque de suas emoções e atenções é particularista para os filhos e o lar" (p.40). A situação econômica mais desfavorecida de nossas depoentes pode ser um dos fatores que ajudam a condicionar seu comportamento de mães e cuidadoras, mas que não substituem totalmente o desejo sentido por elas em ter mais liberdade e tempo para si mesma.

A perda da liberdade é algo relatado pelas mulheres como algo ruim que se deu devido à maternidade tão precoce. Apesar da importância, relatada por elas de cuidar dos filhos, elas se ressentem de terem perdido a liberdade que tinham antes da maternidade. $\mathrm{O}$ fato de terem abdicado de estudar, de sair, de ir a festas, ou seja, de não poder sair para se divertirem é uma situação presente em suas falas.

Observamos que esta comunidade não dispõe de uma rede social de apoio para as mães deixarem seus filhos menores, como creches, pré-escola pública ou escola de tempo integral, fato que lhes tem impossibilitado desenvolver atividades fora do domicílio. Apesar das dificuldades que elas encontram no seu contexto social, elas não se sentem satisfeitas em serem apenas mães e donas de casa, embora valorizem bastante o cuidado com os filhos. Como podemos observar em algumas falas abaixo.

"É eu gosto das minhas filhas e não me arrependo não, porque tive elas, não. Só acho ruim porque não posso estudar, trabalhar essas coisas, só isso. Não achei ruim, porque que eu queria e aconteceu porque eu quis. Só que é ruim ficar presa demais, não ter a liberdade que eu tinha, de tá saindo, como de primeiro, se eu quisesse sair só mais ele, tinha que levar ela; para eu sair com essa tenho que trazer ela pra todo canto que eu vou, só o que fica ruim é isso. A pessoa não tem mais liberdade, antes eu queria sair, pegava e saía, agora não, tem que levar menino, bolsa, essas coisas. A gente fica mais presa" (Maria). 
"Mudou que a pessoa não pode sair, filho empata muito a vida da pessoa. Empata mesmo de estudar, um sonho que a pessoa teve, não realiza, porque tudo vai por água abaixo [...] se o mundo voltasse de novo eu não queria ter filho assim, sabe? Não, não queria ter filho assim logo. Perde a juventude, logo, essa meninada nova de 15 anos de 14,13, engravida logo cedo, pelo menos foi assim como eu, que engravidei logo, com 22 dois anos já tenho três filhos" (Vera).

Giffin e Costa (1999, p. 53), analisando a situação de famílias pobres, afirmam que as mães desse grupo social não têm meios próprios ou públicos que as substituam nas tarefas domésticas, fato que dificulta a manutenção de algumas necessidades básicas como o cuidado dos filhos menores, sendo "subjugadas a outras necessidades igualmente básicas (a provisão de renda pela mãe) o que confirma uma situação contraditória, socialmente determinada".

Leônia dá ênfase ao fato de ser mãe, mas refere-se a esta falta de apoio para deixar os filhos em segurança em uma situação de necessidade.

"Pra mim cinco filhos é um peso, não o peso pra eu carregar, é bom porque eu sei que sou mãe, tenho meus filhos, foi pelo meu gosto porque se eu não quisesse eu tinha evitado, mas é ruim porque a gente quer sair pra uma coisa séria não pode porque não pode deixar com ninguém e nenhuma pessoa quer ficar com cinco filhos de uma vizinha se não for da nossa família" (Leônia).

Essa contradição entre o cuidado doméstico e as suas necessidades de contato com o mundo público deve ser, também, uma das razões destas mulheres não se sentirem satisfeitas em suas necessidades básicas individuais, de ter um espaço para cuidar de si ou de oportunidade para escolher o que fazer, como relatado anteriormente, o lazer, estudo e trabalho, são as situações que sentem terem renunciado devido a serem mães.

"Deixei de estudar por causa da gravidez. E pra mim foi muito difícil que eu era muito nova. Deixei de estudar, uma parte da minha vida eu deixei de fazer, que eu tinha 16 anos, aí passei a ser dona de casa e a responsabilidade era maior, deixei de curtir, ir pras 
festas, deixei de brincar, deixei de muita coisa, não queria ter engravidado tão cedo" (Tieta).

Esta falta de liberdade, ou seja, a restrição e subjugação às condições desfavoráveis em que estão inseridas as impede de pensar em si. A responsabilidade da vida doméstica é mostrada como um peso muito grande para essas jovens mulheres que se sentem sobrecarregadas pelos cuidados com os filhos, casa e esposo e não encontram uma maneira de extravasar ou satisfazer estas necessidades.

\section{Projetos de vida}

Wagner; Facke e Meza (1997) ressaltam o papel fundamental da família, como responsável pela construção dos projetos de vida do adolescente, além dos seus valores e crenças que se realizam na medida em que a família é o cenário onde se vive e aprende primariamente, buscando o equilíbrio entre o real e o imaginário, em que cada sujeito pode ser entendido no seu contexto familiar, considerando que qualquer mudança na família pode afetá-lo.

Encontramos entre as mulheres projetos de vida, relacionados com estudo, trabalho, independência, constituição familiar. Assim vamos analisar os projetos de vida em dois momentos das vidas das depoentes, primeiro antes da gravidez e maternidade, ou seja, na adolescência, e no momento atual de suas vidas.

No relato de Vitória, observamos a falta de perspectiva futura apesar de ser ela, entre as mulheres estudadas aquela que tinha melhor desenvolvimento escolar. Antes da gravidez, não relatou ter nenhum projeto profissional, ou pessoal sobre o futuro.

"Eu acho que não planejei nada pro futuro, eu sempre estudei, mas eu nunca pensei no que eu ia ser, nunca pensei sobre isso, minha irmã tinha vontade que eu fosse o que ela é professora, mas pra mim não dá certo" (Vitória).

Mariana e Isadora, também, não falam de futuro, elas queriam se divertir, curtir a adolescência, não tinham nenhum projeto profissional ou pessoal estabelecido, estavam vivendo o seu momento. A primeira nos conta sobre como se sentia antes da maternidade e expressa que ser mãe mudou o caminho que trilhava, 
“Antes eu só pensava em namorar, sair, dançar a noite toda, chegar de manhã, dormir e ir pra praia, só isso. Não pensava em casar, só estudar e namorar, dançar e tudo, mas depois que eu fui mãe, eu não penso mais não nessas coisas" (Mariana).

Isadora na adolescência fala que,

"Meu desejo naquela época era só sair, me divertir, nem na escola eu pensava direito, que eu estudava, mas nem sabia nem qual era a carreira que eu gostaria de seguir" (Isadora).

Acreditamos que as famílias centradas na mãe como educadora ou provedora, as famílias reconstituídas, assim como a falta de perspectiva escolar e ausência de qualificação para assumir um trabalho formal ou trabalho informal que a maioria delas desenvolvia dentro do contexto doméstico, puderam influenciar direta ou indiretamente nos projetos de vida estabelecidos por estas mulheres.

Os projetos de vida que elas relataram ter, antes da maternidade, eram variados, alguns relacionados com a construção de uma família, em terem um companheiro e filhos; outras em sua independência através do trabalho; também queriam se divertir, ou seja, viver a adolescência sem assumir responsabilidades naquele momento; estudar, mas sem ter ainda estabelecido quais os planos que queriam para o futuro através do estudo ou o que poderiam alcançar. Estes planos foram alterados pela maternidade, o que para algumas passou a ser o cuidado dos filhos, casa e marido, como afirmam Catharino e Giffin (2002, p. 13) que para as adolescentes grávidas envolvidas em seu estudo "[...] dentre as perspectivas futuras estão a constituição da nova família, a criação e os cuidados infantis e a construção da casa própria". Vejamos o que algumas nos contam sobre estes projetos:

"Eu pensava isso mesmo em arrumar assim uma pessoa, em morar com ele numa casa, ter filho, era o que eu pensava, eu pensava nessas coisas [...]" (Maria).

"Eu pensava desde os meus 13, 14 anos que eu já começava a trabalhar em alguma coisa, sempre pensava em trabalhar e ter minhas coisas para nunca depender de ninguém, eu nunca gostei de depender de ninguém pensava em continuar trabalhar em algum 
canto e ter minhas coisas, gostava muito de passear coisas assim" (Uliane).

"Eu sempre pensei em trabalhar, sabe, acho que é isso, trabalhar, num casar nem ter filho, era isso que eu pensava" (Taís).

Apesar dos projetos de constituir uma família serem predominantes nesse grupo, algumas delas não esperavam que isso fosse acontecer "cedo" e terem família e filhos na idade em que tiveram, porém Maria, Leônia e Esmeralda não colocaram outro projeto que não este, o que podemos considerar é que elas ainda não tinham um projeto de vida claramente definido, e isso pode estar relacionado com as condições de vida em que estavam inseridas e que não ofereciam oportunidades que lhes auxiliassem a encontrar um caminho diferente para as suas vidas que não a vida doméstica.

"Eu tinha uns 13 anos quando eu vim pensar mesmo de arrumar uma pessoa pra viver, pra casar mesmo" (Leônia).

"Quando era adolescente não pensava em fazer nada, não. $\mathrm{Na}$ época pensava mais em tomar conta da casa, é isso eu sempre sonhei, ter uma casa, um dia ter um marido, isso que toda mulher sempre sonha, isso eu pensava, como é que ia ser a minha vida quando chegasse a ficar mais velha, ter uma casa e ter meus filhos. Assim de uns vinte anos pra cima, mais só que aconteceu mais cedo, que acontece e a pessoa nunca sabe" (Esmeralda).

Uma pesquisa sobre gravidez na adolescência realizada em dois hospitais públicos de São Paulo apontou que a maioria $(64,08 \%)$ das adolescentes grávidas não tinha claramente definido nenhum projeto de vida; entre aquelas que tinham após a maternidade, fizeram a opção por cuidar do filho, e a minoria ainda se propunha a estudar e ou trabalhar. Isso demonstra que os projetos de vida ainda não estão claramente definidos na adolescência e as circunstâncias fazem com que eles vão se determinando, conforme surgem os acontecimentos nas suas vidas (LIMA; KOBATA; SILVESTRINI, 2000).

Uma outra situação relatada pelas mulheres da pesquisa acerca de seus projetos de vida atuais ou futuros mostra que eles estavam presentes em suas mentes como desejos a serem realizados por elas que vivem há alguns anos uma vida restrita à posição de mães, companheiras e donas de casa. 
A dependência do companheiro e os cuidados com os filhos dificultam para estas mulheres encontrarem seu próprio espaço de desenvolvimento, porém seus projetos giram em torno dos estudos, de um trabalho, de ter sua casa, e na maioria das vezes seus projetos estão voltados para o cuidado com o filho como uma forma de melhorar as condições em que vivem e poderem melhorar a qualidade de vida deles.

"Eu agora eu tenho vontade de estudar, pra poder fazer minha vida melhor, assim ajudar a ele, ter um plano melhor, coisa de estudar. Ele mesmo diz: - eu botava você pra estudar. Eu tenho vontade de aprender alguma coisa, aí eu não posso tá saindo por causa da menina, que a mãe dele é pessoa idosa, velha não posso deixar ela sozinha também" (Evelin).

Uliane estava trabalhando como ambulante na venda de lençóis para cama e pensava em estudar,

"[...] eu estou pensando em fazer um Supletivo pra ver se recupero, mas estou criando vontade e coragem, que eu nunca fui muito a fim de estudar, mas não vou fazer agora porque não posso estudar e deixar meus filhos à toa nas casas dos outros. Vou estudar no dia que eu vê que eles podem se cuidar sozinhos, quando eu estiver trabalhando e possa pagar uma pessoa pra olhar eles. [...] Pra eu querer dar um futuro melhor pros meus filhos, eu vou ter que estudar pra poder trabalhar melhor, que hoje em dia sem estudo não ganha nada" (Uliane).

Das mulheres, apenas Isadora estava estudando, cursava a oitava série do Ensino Fundamental e trabalhava como faxineira em uma residência e tinha planos de concluir os estudos e entrar em uma universidade.

"Passei cinco anos sem estudar. Agora eu voltei a estudar pra ver se eu concluo o Ensino Médio, ver se consigo fazer o que quero. Eu, eu quero fazer medicina, eu quero fazer fisioterapia. [...] Eu pretendo continuar minha luta, mas é difícil. A gente tem que tentar dar uma melhor educação, a gente mesmo tem que ter [...] o futuro 
é batalhar, ter um emprego melhor ou então terminar meus estudos, que eu quero ver se eu consigo alcançar o meu objetivo" (Isadora).

As outras permaneciam como dona de casa, cuidando dos filhos e/ou dos maridos, apesar de manifestarem outros desejos. Maria manifesta seu conformismo por não ter outra alternativa em sua vida, após ter engravidado na adolescência. Ela gostaria de estar com seus 21 anos, mas sem filhos e trabalhando e pensando em ter filhos quando tivesse um pouco mais de idade, apesar de ter colocado que não havia arrependimento por ser mãe, pois ficou grávida pela primeira vez, com 15 anos, porque queria uma menina.

"Eu queria tá assim, com 21 anos livre de filhos, trabalhando, pra depois eu pensar nisso [...] Se eu pudesse voltar no tempo eu acho que faria a mesma coisa, já imaginou todo mundo tem filho e a pessoa não ter nenhum. [...] Acho que não tão nova, mas um pouquinho com a idade mais avançada. [...] Eu não ia ter filho não, assim de menor, ia brincar bastante, ia trabalhar, namorar bastante [...]" (Maria).

O desejo de ter uma atividade remunerada é quase que uma constante nos depoimentos, porém este desejo não é colocado como uma forma de libertação da relação de dependência masculina ou de realização pessoal, mas sim como uma alternativa de melhorar sua condição de vida e suprir melhor as necessidades dos seus filhos. Dessa forma, observamos que os projetos de vida dessas mulheres, que foram mães na adolescência, com seus desejos de entrarem na vida pública, têm como objetivo final a vida doméstica, como uma forma de melhorar as expectativas de vida de seus filhos para lhes darem melhor oportunidade de educação. Em seus relatos elas nos disseram:

"Eu penso em trabalhar de tanta coisa, eu quero trabalhar numa empresa, mas é difícil que eu não tenho meus estudos completos, não tenho nenhum curso, pra isso precisa de curso, a única maneira é em casa de família, mas eu não pretendo não ir pra casa de família, porque não é muito bom a gente trabalhar em casa de família, que a gente só leva rela na cara, tem que ser tudo na hora certa que eles querem. Preciso terminar, pretendo terminar meus estudos, pra fazer um curso pra arranjar um trabalho, nem que seja o de faxineira, tem empresa que pega pessoa pra fazer faxina, pra 
trabalhar na limpeza. Pretendo estudar pra ter um serviço melhor pra educar minhas filhas" (Tieta).

"Penso em trabalhar, cuidar dela, logo ela vai estudar, colocar ela num colégio pra ela estudar. Quero trabalhar, ver se continuo meus estudos que eu não terminei, parei de estudar pra casar e o que eu ganhei, mas eu vou estudar, botar ela pra estudar também e pronto" (Mariana).

Santos (2001), em sua pesquisa, encontrou em vários depoimentos que as mães desejavam solução dos problemas relacionados às condições materiais de suas vidas, fato que corrobora com o de nossas depoentes, como afirma Evelin “[...] eu tenho vontade de estudar, pra poder fazer minha vida melhor, assim ajudar a ele [...]", este desejo não é só para ela, a família é o objetivo principal.

Em outros relatos, encontramos que os projetos das mães estão diretamente relacionados com o cuidado dos seus filhos, educar e oferecer uma condição de vida melhor, e assim observamos, de uma forma indireta, a insatisfação das mesmas com a maneira como suas vidas estão organizadas, mas poucas voltam seu interesse em melhorar sua própria vida, os desejos estão sempre colocados na satisfação do outro, ou seja, seus filhos e parceiros, fato que podemos constatar nos relatos abaixo:

"O meu plano mesmo é ter minha casa, chegar a ter minha casa, só isso mesmo, botar os meus filhos pra estudar, pra eles crescerem e serem pessoas normais, são esses os meus planos daqui pra frente" (Esmeralda).

"Eu queria poder morar na minha casa, pra que se chegar o tempo de morrer eu ou então ele os meus filhos terem onde ficar, não ficar na casa de família sofrendo. [...] gostaria de trabalhar em qualquer coisa que aparecesse, que preciso pra ajudar meu marido. Eu ia poder dar assim... chegar um final de semana poder comprar roupa pra eles, comprar alguma coisa pra eles pronto [...] Aí no futuro eu queria poder dar o que não posso. Poder pagar escola pros meus filhos que eu não tenho condições de pagar [...]"(Caroline) 
Outro ponto que vale ressaltar é que, apesar de terem projetos para suas vidas, existe uma dificuldade de concretizá-los que está relacionada à falta de uma rede de apoio, seja familiar ou social para cuidar dos filhos, na ausência das mesmas, que lhes dê segurança para sair de casa para estudar ou trabalhar.

Vera não vê condições de realizar seu projeto e lamenta que o seu sonho terminou,

"Tenho vontade de estudar, voltar a estudar, de se um dia me formar, mas eu acho que meu sonho já acabou. [...] estudar e me formar, para depois eu ver o que eu quero ser, eu ainda estou com 22 anos, estou nova, tenho um futuro ainda pela frente. Gostaria de, primeiramente minha saúde e a dos meus filhos e condições financeiras para dar o que os meus filhos precisam, pra serem mais gente no futuro" (Vera).

No caso de Vitória, ela não consegue se afastar dos filhos, ela relata que quer estar sempre com eles, não confia em deixá-los com outras pessoas, demonstra ser bastante possessiva na relação com seus filhos, o que dificulta qualquer possibilidade de se desenvolver ou de se interessar por algo fora de seu ambiente familiar. A identidade materna é muito forte, mas é vivida em circunstâncias que dificultam o seu desenvolvimento individual. Ela nos conta que:

"A escola gostaria de ter terminado. O tempo que eu fiquei sem estudar seis anos, e o $2^{\circ}$ e o $3^{\circ}$ ano que eu tinha terminado com dois anos, os outros quatro anos dava tempo eu ter feito outra coisa. [...]. Agora, não tenho vontade de fazer nada mais, eu num gosto nem de sair pra deixar eles. Tenho que sair pra um lugar que eu possa levar todo mundo [...] Também eu penso em trabalhar, mas também não tenho vontade de deixar eles com outra pessoa pra mim trabalhar. Eu não confio em ninguém pra ficar com os meninos assim. A única pessoa que eu saio e que eu confio de deixar é minha mãe [...]" (Vitória).

Essas mulheres não mostram nenhuma identificação com a imagem da mulher atual, aquela que estuda, que quer se profissionalizar, que tem entre os seus projetos pessoais a busca de sua realização no mundo público e a busca da sua felicidade, por meio 
do reconhecimento e sucesso fora do espaço doméstico. Elas ainda se identificam com o modelo tradicional da mulher cujos projetos mantêm-se relacionados à conjugação "mãe" e esposa".

Observamos, de modo geral, que as mulheres de nosso estudo, realmente, convergiram suas vidas para a maternidade e o mundo doméstico, um papel historicamente feminino e conseqüentemente seus sonhos e aspirações giram em torno de melhorar as condições de suas vidas e de seus filhos. O nível de insatisfação com a vida a que estão subordinadas, principalmente, com a falta de liberdade de realizar seus sonhos, está expresso na dificuldade que têm de terem oportunidades de lazer, de trabalho e de retornar aos estudos.

Elas falam de seus projetos no sentido de buscar soluções para resolver as dificuldades materiais em que vivem, pois, como vimos a maioria delas, depende exclusivamente do que seus parceiros percebem com seu trabalho e elas não conseguem satisfazer todas as necessidades de sobrevivência da família. Assim podemos destacar que seus desejos prioritários são melhorar o seu cotidiano e o de sua família. 


\section{CONSIDERAÇÕES FINAIS}

Neste capitulo final não pretendemos fazer nenhuma conclusão, entretanto gostaríamos de realizar algumas reflexões sobre o tema estudado, pois as histórias das mulheres participantes de nossa pesquisa, cuja maternidade ocorreu na adolescência, foram mais ricas e expressivas de informação do que conseguimos apreender ao longo do processo de construção deste estudo, não sendo possível esgotar todo o seu conteúdo.

O objeto deste estudo foi centrado na construção social da maternidade na adolescência na periferia de uma cidade no Nordeste brasileiro. Tínhamos como pressuposto que as mulheres colaboradoras de nosso estudo, oriundas de uma camada social mais desfavorecida economicamente, puderam estabelecer na maternidade na adolescência seu projeto de vida. Entretanto essa escolha as impossibilitaram de concretizar novos projetos que lhes dessem condições e poder de negociação e enfrentamento das desigualdades de gênero vividas com seu parceiro.

Ao utilizarmos o referencial de gênero para subsidiar a análise deste estudo, sentimo-nos satisfeitas pelos resultados alcançados, acreditando que o objetivo e o propósito deste estudo foram alcançados. Da mesma maneira, consideramos ter sido válido o procedimento metodológico adotado no curso desta pesquisa, oriundo do campo da história, que implicou reconhecer em um grupo de mulheres, cuja ocorrência da maternidade se deu na adolescência, como essa ocorrência influiu na organização de suas vidas.

Procurar compreender as histórias dessas mulheres, que foram mães na adolescência, foi uma experiência muito gratificante, tanto no campo profissional como no pessoal, pois tivemos o privilégio delas terem aceitado compartilhar suas experiências conosco. Suas histórias nos possibilitaram tecer várias considerações sobre a trajetória da maternidade na adolescência tendo o gênero, como referencial interpretativo. 
Esse processo nos possibilitou uma retomada de momentos vividos por elas, como: relações familiares, escola, trabalho, namoro, perda da virgindade, contracepção, gravidez/maternidade, relações conjugais e projetos pessoais.

As mulheres nos trouxeram em suas narrativas a participação paterna em suas vidas e nas dos filhos, e assim pudemos realizar uma reflexão sobre as relações de gênero presentes nessas histórias que começaram antes da primeira gravidez, entretanto percebemos que as relações de gênero teriam sido mais bem compreendidas, se tivéssemos incluído as histórias de vida dos homens envolvidos.

Percebemos que as mulheres de nosso estudo vivenciaram a adolescência por um curto período ou passaram praticamente sem vivê-la, pois face às circunstâncias de sua vida foram obrigadas a amadurecer precocemente, quando se inseriram no trabalho infantil e iniciaram sua vida sexual.

Pudemos observar que o processo de socialização vivido por essas mulheres na infância e adolescência, por meio dos laços familiares, a vida familiar, a relação com o mundo público, mediante sua participação na escola e no trabalho infantil, foram cruciais para a construção social da maternidade na adolescência, como algo natural que deve ser exercida por elas, mesmo quando não planejada.

Nessa vivência fica estabelecida a desvantagem social que as levaram a não terem oportunidades de romper um ciclo de desigualdade. Os papéis de gênero começam a ser apreendidos na infância e as mulheres de nosso estudo tiveram seu aprendizado através de situações de subordinação quando, se viram obrigadas a se inserir precocemente no trabalho doméstico, que tradicionalmente são atividades femininas, fosse ele remunerado ou não, construindo seu aprendizado voltado para os papéis femininos e sendo exploradas em seu exercício.

A relação dessas mulheres frente à sexualidade e à reprodução parece estar inscrita nos modelos mais tradicionais de relações sociais, estando baseadas na busca da construção de um núcleo familiar em que essa mulher assume um papel perante a sociedade em que está inserida, porém este papel traz consigo uma desigualdade de gênero em que o homem exerce um poder patriarcal inserido nessa sociedade e aceito por estas mulheres. 
Um aspecto importante que observamos, dentro desta construção de gênero simbólica e coletiva, é que a maternidade fazia parte do imaginário da maioria, das mulheres antes da ocorrência da primeira gravidez. Porém essa maternidade não era um projeto de vida de todas as mulheres estudadas, para ser concretizado na adolescência.

Vale destacar que, apesar da primeira gravidez não ter sido planejada, a maioria das gravidezes não foi indesejada e as mulheres aceitaram-nas e assumiram a maternidade, obtendo visibilidade no mundo social em que viviam.

Os significados da maternidade na adolescência que pudemos apreender por meio das histórias das mulheres participantes desta pesquisa foram vários, mas principalmente o desejo de constituir sua própria família.

Embora o casamento e a maternidade façam parte de seus desejos e/ou projetos de vida, a concretização deles não lhes traz satisfação completa, ou seja, a realização pessoal não se deu somente pelo exercício do papel de esposa e mãe, que talvez, em seu imaginário esperassem que acontecesse.

As mulheres de nosso estudo têm consciência do que tiveram de abdicar para assumirem a maternidade e o casamento e fazem referência ao que tiveram que renunciar como a liberdade de sair, o lazer, a possibilidade de trabalho e de continuar com seus estudos devido à maternidade e que talvez por isso devessem ter esperado um pouco mais para concretizá-los.

Consideramos que apesar de se esperar, em um modelo mais tradicional de sociedade, que as mulheres tenham um comportamento mais restritivo à vida privada, elas não se sentem realizadas como mulheres, apenas exercendo o papel feminino voltado integralmente para o espaço doméstico.

Elas vivem uma vida de desigualdade entre seus parceiros, pois devido as suas funções reprodutivas vivem uma divisão sexual do trabalho, tendo o seu dia-a-dia centrado na rotina doméstica, voltada para os cuidados com a casa, os filhos e o parceiro, ocupações tidas como femininas. As mulheres estudadas, apesar de na atualidade questionarem essa situação, assumem as tarefas domésticas não tendo oportunidades de vivenciar uma relação conjugal mais igualitária, podendo defender sua liberdade sexual com autonomia sobre sua vida reprodutiva. 
Os parceiros assumem a paternidade, constituindo com as mulheres que engravidaram na adolescência um núcleo familiar. Eles exercem a função de provedores, desenvolvendo atividades remuneradas fora do âmbito doméstico. A vida dessas mulheres está organizada sob dominação masculina em decorrência do sistema familiar que construíram e a dependência financeira que elas têm dos seus parceiros.

Essas mulheres que tiveram sua adolescência marcada pelas desigualdades declararam que seus projetos de vida são de estudar e/ou de se inserirem no mercado de trabalho, porém devido ao contexto de vida em que vivem, com ausência de rede de apoio social para ela e seus filhos, têm dificuldades para concretizá-los.

Pela falta de oportunidades e liberdade de escolha, os cuidados com filhos é o que tem de mais valor em suas vidas, pois todos os seus projetos trazem como pano de fundo poder oferecer melhores condições de vida para eles, com melhores oportunidades de estudos, coisa que elas não tiveram, mas que consideram importantes para buscar romper a imobilidade social imposta.

As mulheres de nosso estudo, também, conseguem analisar as modificações que tiveram de fazer para assumir a maternidade e se ressentem do "encarceramento" doméstico em que vivem, entretanto para alterar esse padrão seria necessário romper com essa ordem do poder instituído pelo modelo social em que vivemos, com tantas desigualdades sociais.

Podemos identificar que os desejos, sonhos e aspirações da maioria das mulheres estudadas estavam voltados para o mundo doméstico: ter filho, encontrar um parceiro, ter sua casa, estudar e trabalhar para a família. Podemos inferir que esta é a forma que encontraram de estarem inseridas em seu mundo social, com um papel eminentemente feminino, podendo ser reconhecidas por ele neste ambiente.

Existem, em seus projetos de vida futura, a possibilidade de inserção no mercado de trabalho e o retorno aos estudos como uma busca de melhorar as condições de vida da família. Isso não acontece devido às adversidades vivenciadas que parecem mascarar seus desejos de realização pessoal, e assim seus desejos de inserção no espaço público não passam pela necessidade de ter a garantia de assegurar direitos iguais para homens e mulheres, exercendo assim plena cidadania. 
A trajetória de vida dessas mulheres que foram mães na adolescência nos mostra as diversas formas de se viver a maternidade, mas uma situação, podemos dizer que é comum a todas elas, são as circunstâncias de vida em que vivem, marcada pela pobreza e pela desigualdade social. Isso nos causa consternação visto que são garantidas na Constituição desde 1998, políticas públicas de proteção ao cidadão, à criança, ao adolescente, à mulher e à família e estas políticas não conseguem atingir uma camada da população desfavorecida de forma a lhes garantir oportunidades de romper o ciclo da pobreza e assimetrias de gênero, restringindo o exercício da cidadania.

Observamos que a maternidade tem um significado importante para elas e que, apesar de associarem as modificações sofridas na vida devido a ela, fizeram questão de afirmar que não se arrependem de terem sido mães, porém o exercício dessa maternidade contribui para a manutenção das desigualdades de gênero e sociais em que foram criadas.

Vale destacar que elas analisam que poderiam ter tido menos filhos ou que poderiam ter esperado serem adultas para realizarem este sonho. Isso poderia ter sido alcançado se a elas fosse garantido o direito de livremente escolher em que momento seriam mães, pois, devido a todas as circunstâncias de vida em que elas viviam, lhes faltou liberdade de exercer seu direito no controle da reprodução e de compartilhá-lo com seu parceiro, um vez que defender os direitos reprodutivos para as mulheres significa também estender esses direitos para os homens.

A gravidez/maternidade na adolescência é considerada um problema de saúde pública, porém consideramos que não seja ela o problema, mas sim a desigualdade social existente que não dá a todas (os) membros de nossa sociedade as mesmas oportunidades de escolha e a mesma qualidade de vida. Observamos que as ações de educação e orientação sexual para os adolescentes, existentes nos serviços públicos na área de ensino e saúde, não tiveram impacto nessa população.

Os profissionais de saúde, entre eles os (as) enfermeiros (as), devem estar atentos aos significados da maternidade para as mulheres e para os homens, compreendendo essa ocorrência inserida num contexto cultural que pode diferir de local para local. Assim sendo é necessária uma atenção, não à saúde ou à doença, mas à pessoa o que pode facilitar a inter-relação e a sua melhor interpretação pode contribuir para uma ação mais efetiva. A transformação da visão dos profissionais ao lidar com a gravidez/maternidade na 
adolescência é um processo que pode garantir o atendimento dos jovens em seus direitos reprodutivos e sexuais.

A compreensão desse fenômeno pode trazer subsídios para uma assistência voltada para as reais necessidades deste grupo, pois várias mudanças ocorreram na vida dessas mulheres. Este evento, esta vinculado à construção e à organização social desse grupo, um vez que não podemos separar as desigualdades sociais existentes e as desigualdades de gênero, das questões econômicas, políticas e sociais.

É necessário que nós reconheçamos que os adolescentes necessitam de atenção e de orientação sobre sua sexualidade e saúde reprodutiva, que lhes seja oferecida a oportunidade de fazer escolhas livres e viver sua vida sexual com plenitude, porém, com mais segurança e para isso é imprescindível a participação de mulheres e homens nessas escolhas.

Entendemos que, para modificar a situação dessas mulheres, é necessário romper com o ciclo de pobreza em que estão inseridas, entretanto o empoderamento das mesmas pode ajudá-las a se reconhecer como mulher, cidadã com direitos que devem ser respeitados, não apenas serem reconhecidas como mães.

As políticas públicas brasileiras são dirigidas aos direitos dos cidadãos e esses direitos "teoricamente" voltados para a justiça social, sendo necessário aplica-las, levando em consideração as situações de desigualdades sociais, de gênero, de classe e de raça existentes em nossa sociedade. 


\section{REFERÊNCIAS*}

AGÊNCIA DE NOTÍCIAS DOS DIREITOS DA INFÂNCIA [ANDI]. Perguntas mais
Freqüentes. $\begin{array}{lccc}\text { Freqüentes. } & \text { Brasília, } & \text { s/d. } & \text { Disponível } \\ <\text { http://www.andi.org.br/tid/conteudo/lnk/index.asp>. Acesso em: } 29 \text { dez. } 2004 .\end{array}$

ALTHOFF, C.R. Delineando uma abordagem teórica sobre o processo de conviver em família. In: ELSEN, I.; MARCON, S.S.; SANTOS, M.R. O viver em família e sua interface com saúde e a doença. Maringá: Eduem, 2002. p.25-43.

AMAZONAS, M.C.L.AL.; DAMASCENO, P.R.; TERTO, L.M.S.; SILVA, R.R. Arranjos familiares de crianças das camadas populares. Maringá. Psicol. estud., v.8, n. esp. p. 1120, 2003. Disponível em: $<$ http://www.scielo.br/cgibin/wxis.exe/iah/?\&IsisScript=iah\%2Fiah.xis\&base $=$ article\&nextAction=lnk\&fmt=iso.pft \&lang $=\mathrm{p} \&$ exprSearch $=$ arranjos + and + familiares $>$. Acesso em: 03 maio 2005.

AQUINO, E.M.L.; HEIBORN, M.L.; KANAUTH, D.; BOZON, M.; ALMEIDA, M.C.; ARAUJO, J.; MENEZES. Adolescência e reprodução no Brasil: a heterogeneidade dos perfis sociais. Cad. Saúde Pública, Rio de Janeiro, v. 19, n. 2, p. S377-88, 2003.

ARILHA, M. Contracepção, empowerment e etitlemente: um cruzamento necessário na vida das mulheres. In: BERQUÓ, E. (Org.) Reflexões sobre gênero e fecundidade no Brasil. Campinas: Family Health Internacional, 1999a, p. 2-15. Disponível em: $<$ http.//www.prossiga.br/fsp_usp/saudereprodutiva>. Acesso em: 24 agos. 2003.

ARILHA, M. Homens, saúde reprodutiva e gênero: o desafio da inclusão. In: GIFFIN,K.; COSTA, S.H. (Org.). Questões da saúde reprodutiva. Rio de Janeiro, Fiocruz, 1999b. p.455-67.

BADINTER, E. Por mal caminho. Traducción Dolores Mascarell Pellicer. Madrid: Alianza, 2004.

BADINTER, E. Um amor conquistado: o mito do amor materno. 4. ed. Tradução Waltensir Dutra. Rio de Janeiro: Nova Fronteira, 1985.

BADINTER, E. X Y: La identidad masculina. Traducción Monserrat Casals. Madrid: Alianza, 1993. 254 p.

BARROSO, C.; BRUCHINI, C. Apresentação e planejando o programa. In: BARROSO, C.; BRUCHINI, C. Sexo e juventude: como discutir a sexualidade em casa e na escola.

De acordo com:

ASSOCIAÇÃO BRASILEIRA DE NORMAS TÉCNICAS. NBR 6023: informação e documentação: referências: elaboração. Rio de Janeiro, 2002. 
São Paulo: Cortez, 1991. p.7-14.

BARSTED, L.L. Família, sexualidade e reprodução no direito brasileiro. . In: GIFFIN,K.; COSTA, S.H. (Org.). Questões da saúde reprodutiva. Rio de Janeiro: Fiocruz, 1999. p.51-78.

BELO, M. A.V.; PINTO E SILVA, J. L. Conhecimento, atitude e prática sobre métodos anticoncepcionais entre adolescentes gestantes. Revista Saúde Pública, São Paulo, v.38, n. 40, p. 479-87, 2004. Disponível em: <http://www.fsp.usp.br/rsp >. Acesso em: 15 dez. 2004.

BENERÍA, L.; SEM, G. Desiguadades de clase y de géneroy el rol de la mulher em el desarrollo econômico:implicaciones teóricas y prácticas. In: LEÓN. M. Debate sobre la mujer em América Latina y el Caribe. Bogotá: ACEP, 1982. v. 4, p.65-79.

BERQUÓ, E. Prefácio . In: BERQUÓ, E. (Org.) Reflexões sobre gênero e fecundidade no Brasil. Campinas: Family Health Internacional, 1999, Disponível em: $<$ http.//www.prossiga.br/fsp_usp/saudereprodutiva>. Acesso em: 24 ago. 2003.

BERQUÓ, E. Sexualidade e demografia. In: LOYOLA, M.A. (Org.). Sexualidade nas ciências humanas. Rio de Janeiro: UERJ, 1998. p. 305-7.

BERQUÓ, E.; CAVENAGHI, S. Direitos reprodutivos de mulheres e homens face à nova legislação brasileira sobre esterilização voluntária. Cad. Saúde Pública, Rio de Janeiro, v. 19, sup. 2, p. S441-S453, 2003.

BONZON, M. Demografia e sexualidade. In: LOYOLA, M.A. (Org.). Sexualidade nas ciências humanas. Rio de Janeiro: UERJ, 1998. p. 227-51.

BOZON, M. Sociologia da sexualidade. Rio de Janeiro: FGV, 2004.

BRANDÃO, E.R. Iniciação sexual e afetiva: exercício da autonomia juvenil. In. HEILBORN, M.L. Família e sexualidade. Rio de Janeiro: Editora FGV, 2004. p. 63-86.

BRASIL. Ministério da Saúde. Assistência ao Planejamento Familiar. Secretaria Executiva. Coordenação de Saúde da Mulher - Brasília: COSAM. 1996.

BRASIL. Constituição (1988) Constituição da República Federativa do Brasil. 24. ed. São Paulo: Atlas, 2005.

BRASIL. Ministério da Saúde. Assistência integral à saúde da mulher: bases de ação programática. Brasília, Centro de Documentação do Ministério da Saúde , 1984.

BRASIL. Ministério da Saúde. Datasus: indicadores de saúde. Brasília, 2004. Disponível em: <http://www.datasus.gov.br...>. Acesso em: 30 jun. 2004.

BRASIL. Ministério da Saúde. Secretaria de Assistência à Saúde. Departamento de Assistência e Promoção à Saúde. Coordenação Materno-Infantil. Serviço de Assistência à Saúde do Adolescente. Normas de atenção à saúde integral do adolescente. Brasília, 1993a. v. 1. 
BRASIL. Ministério da Saúde. Secretaria de Assistência à Saúde. Departamento de Assistência e Promoção à Saúde. Coordenação Materno-Infantil. Serviço de Assistência à Saúde do Adolescente. Normas de atenção à saúde integral do adolescente. Brasília. 1993b. v. 2.

BRASIL. Ministério da Saúde. Secretaria de Educação Básica. Departamento de Políticas de Educação Infantil e Ensino Fundamental. Brasília/DF, 2005. Disponível em: < http://www.mec.gov.br/seb/ensmed/pol_infantil.shtm>. Acesso em: 04 maio 2005.

BRITO, M.N.C. Gênero e cidadania: referenciais analíticos. Rev. Estud. Fem, Florianópolis, v. 9, n.1, p.291-298, 2001. Disponível em: $<$ http://www.scielo.br/scielo.php?script=sci_arttext\&pid=S0104-

026X2001000100017\&lng=pt\&nrm=isso>. Acesso em 28 abr. 2003.

BRUNO, Z.V.; BAYLEY, P. Gravidez em Adolescentes no Ceará: maternidade ou aborto. In: VIEIRA, E.M. FERNANDES, M.E.L.; BATLEY, P.; MCKAY, A. (Org.). Seminário Gravidez na Adolescência. Rio de Janeiro: Ministério da Saúde/Family Health International/Associação Saúde, 1998. p.57-66.

BRUSCHINI, C. Maternidade e trabalho feminino: sinalizando tendências. In: BERQUÓ, E. (Org.). Reflexões sobre gênero e fecundidade no Brasil. Campinas: Family Health Internacional, 1999, Disponível em: <http.//www.prossiga.br/fsp_usp/saudereprodutiva $>$. Acesso em: 24 ago. 2003.

CAMARANO, A.A. ARAUJO, H.A.; CARNEIRO, I.C. Tendências da fecundidade brasileira no século XX: uma visão regional. In: GIFFIN,K.; COSTA, S.H. (Org.). Questões da saúde reprodutiva. Rio de Janeiro: Fiocruz, 1999. p.95-111.

CAMARANO, A.A. Fecundidade e anticoncepção da população de 15-19 anos In: VIEIRA, E.M. FERNANDES, M.E.L.; BATLEY, P.; MCKAY, A. (Org.). Seminário Gravidez na Adolescência. Rio de Janeiro: Ministério da Saúde/Family Health International/Associação Saúde, 1998b. p. 35-46.

CAMARANO, A.A. Fecundidade e anticoncepção da população jovem. In: BRASIL. Jovens acontecendo na trilha das políticas públicas. Brasília: Comissão Nacional de População e Desenvolvimento, 1998a. v. 2, p. 109-133.

CATHARINO, T.R.; GIFFIN, K. Gravidez e adolescência - investigação de um problema moderno. In. ENCONTRO DA ASSOCIAÇÃO BRASILEIRA DE ESTUDOS POPULACIONAIS, 8., 2002, Ouro Preto. Trabalho apresentado (na íntegra). Ouro Preto, 2002.

CHIZZOTTI, A. Pesquisa em Ciências Humanas e Sociais. 4. ed. São Paulo: Cortez, 2000.

CHODOROW, N. Estrutura familiar e personalidade feminina. In: ROSALDO, M.; LAMPHERE, L. A mulher a cultura e a sociedade. Rio de Janeiro: Paz e Terra, 1979. p. 65-94.

CIPRIANI, R. Biografia e cultura - da religião à política. In: SIMSON, O.M.V. 
Experimentos com histórias de vida. São Paulo: Vertice. 1988. p.106-76.

CLAPIS, M.J. Qualidade de vida de mulheres com câncer de mama - uma perspectiva de gênero. 1996. 253p. Tese (Doutorado) - Escola de Enfermagem de Ribeirão Preto, Universidade de São Paulo, Ribeirão Preto, 1996.

CORRÊA, S. Saúde reprodutiva, gênero e sexualidade: legitimação e novas interrogações. In: GIFFIN,K.; COSTA, S.H. (Org.). Questões da saúde reprodutiva. Rio de Janeiro: Fiocruz, 1999. p. 39-49.

COSTA, S.G.. Proteção social, maternidade transferida e lutas pela saúde reprodutiva. Rev. Estud. Fem., Florianópolis, v. 10, n. 2, p.301-323, jul./dez. 2003. Disponível em: $<\mathrm{http}: / /$ www.scielo.br/scielo.php?script=sci_arttext\&pid=S0104-

026X2002000200003\&lng=pt\&nrm=iso $>$ Acesso em: 25 set. 2002.

DESLANDES, S.F; ASSIS, S.G. Abordagens quantitativas e qualitativas em saúde: o diálogo da diferenças. In: MINAYO, M.C. S.; DESLANDES, S.F. Caminhos do pensamento: epistemologia e método. Rio de Janeiro: Fiocruz, 2002. p. 195-223.

DIAS, A.C.G.; OLIVEIRA, V.Z.; GOMES, W.B. A experiência de ser gestante adolescente. Rev. Gin. \& Obst., São Paulo. v. 8, n. 3, p. 161-7,1997.

DRESSER, N.A. Adolescência: sexualidade e culpa. Rio de Janeiro: Rosa dos Ventos, 1993.

EGYPTO, A.C.; EGYPTO, M.M. Papéis sexuais. In: BARROSO, C.; BRUCHINI, C. Sexo e juventude: como discutir a sexualidade em casa e na escola. São Paulo: Cortez, 1991. p.50-5.

EGYPTO, M.M. Namoro e relações sexuais fora do casamento. In: BARROSO, C; BRUCHINI, C. Sexo e juventude: como discutir a sexualidade em casa e na escola. São Paulo. Cortez. 1991. p.35-49.

ELÓSEGUI, M.I. Diez temas de gênero: hombre y mujer ante los derechos productivos y reproductivos. Madri: Ediciones Internacionales Universitárias, 2002.

FAMILY CARE INTERNATIONAL. Compromisos para la salud y los derechos sexuales y reproductivos de todos: marco de acción. Nova York: Family Care Internacional, 1995.

FERRAZ, E.F.; FERREIRA, I.Q. Início da atividade sexual e características da população adolescente que engravida. In: VIEIRA, E.M. FERNANDES, M.E.L.; BATLEY, P.; MCKAY, A. (Org.). Seminário Gravidez na Adolescência. Rio de Janeiro: Ministério da Saúde/Family Health International/Associação Saúde, 1998, p. 67-31.

FERREIRA, A.B.H. Minidicionário da língua portuguesa. 3. ed. Rio de Janeiro: Nova Fronteira, 1993.

FERREIRA, S.L.; NASCIMENTO, E.R.; PAIVA, M.S. Reflexões teórico-metodológicas sobre o conceito de gênero aplicado à pesquisa em enfermagem. In: SEMINÁRIO 
NACIONAL DE PESQUISA EM ENFERMAGEM. 12. 2003, Porto Seguro, Anais. Porto Seguro: Associação Brasileira de Enfermagem/seção Bahia, 2003. CD-ROM.

FORNA, A. Mãe de todos os mitos: como a sociedade modela e reprime as mães. Rio de Janeiro: Ediouro, 1999.

FOUCAULT, M. História da sexualidade: a vontade de saber. 14. ed. Rio de Janeiro: Graal, 2001a. v. 1.

FOUCAULT, M. História da sexualidade: o uso dos prazeres. 9. ed. Rio de Janeiro: Graal, 2001b. v. 2.

FOUCAULT, M. O nascimento do hospital. In: . Microfísica do poder. 17. ed. Rio de Janeiro: Graal, 2002. p.99-128.

FOUGEYROLLAS-SCHWEBEL, D. Movimentos Feministas. In. HIRATA, H. LABORIE, F. DOARÉ, H. SENOTIER, D. Diccionario crítico del feminismo. Traducción Tereza Agustín. Madri: Editorial Sintesis, 2002, p.158-163.

FRAISSE, G. El concepto filosófico de gênero. In: TUBERT, S. Del sexo al género: los equivocos de un concepto.Madrid: Ediciones Cátedra, 2003. p.39-46.

FREITAS, S.M. Préfacio à edição brasileira. In: THOMPSON, P. A voz do passado: história oral. 2. ed. Tradução Lólio Lourenço de Oliveira. Rio de Janeiro: Paz e Terra, 1998. p.14-9.

GIFFIN, K. Corpo e conhecimento na saúde sexual: uma visão sociológica. In: GIFFIN,K.; COSTA, S.H. (Org.). Questões da saúde reprodutiva. Rio de Janeiro: Fiocruz, 1999. p.79-91.

GIFFIN, K; COSTA. S. As práticas contraceptivas e o aborto no Brasil. In: BERQUÓ, E. (Org.). Reflexões sobre gênero e fecundidade no Brasil. Campinas: Family Health Internnational, 1999. Disponível em: <http.//www.prossiga.br/fsp_usp/saudereprodutiva $>$. Acesso em: 24 ago.2002.

GIL, A.C. Métodos e técnicas de pesquisa social. 5. ed. São Paulo: Atlas, 1999.

GREGORI, M.F. A transição da fecundidade e a violência contra a mulher. In: BERQUÓ, E. (Org.). Reflexões sobre gênero e fecundidade no Brasil. Campinas: Family Health Internnational, 1999. Disponível em: < http.//www.prossiga.br/fsp_usp/saudereprodutiva $>$. Acesso em: 24 ago.2002.

GUIMARÃES, E.M.B. Gravidez na adolescência: uma visão multidisciplinar. Pediatria Moderna, São Paulo. v. 37, ed. esp, p. 29-32, maio 2001.

HEILBORN, M.L. AQUINO, E. KANAUTH, D. VICTORA, C. ROHDEN, F. MCCALUM, C. Gravidez na adolescência: estudo multicêntrico sobre jovens, sexualidade e reprodução no Brasil. In: CONGRESSO DE SAÚDE COLETIVA. 6. 2000, Salvador. Anais. Salvador: Abrasco, 2000. CD. ROM. 
HEILBORN, M.L. Fronteiras simbólicas: gênero, corpo e sexualidade. In: PITANGY, J.; MESQUITA, R. Gênero, Corpo e Enfermagem. Rio de Janeiro: CEPIA, 2002. p. 73-92.

HEILBORN, M.L. Gravidez na adolescência: considerações preliminares sobre as dimensões culturais de um problema social. In: VIEIRA, E.M. FERNANDES, M.E.L.; BATLEY, P.; MCKAY, A. (Org.). Seminário Gravidez na Adolescência. Rio de Janeiro: Ministério da Saúde/Family Health International/Associação Saúde, 1998, p. 23-31.

INSTITUTO BRASILEIRO DE GEOGRAFIA E ESTATÍSTICA. Censo demográfico. Brasil: IBGE, 2000.

KERGOAT, D. Relações sociais de sexo e divisão sexual do trabalho. In: LOPES, M.J.; MEYER, D.E.; WALDOW, V.R. Gênero e Saúde. Porto Alegre: Artes Médicas, 1996. p. 19-27.

LIMA, M.S.S; KOBATA, C.M.; SILVESTRINI, W.S. Perfil de adolescentes grávidas, internadas em dois hospitais públicos. A Folha Médica, São Paulo, v. 4, n. 119, p. 59-65, 2000 .

LOURO, G.L. Gênero, sexualidade e educação. Petrópolis: Vozes, 1997.

LOURO, G.L. Nas redes do conceito de gênero. In: LOPES, M.J.; MEYER, D.E.; WALDOW, V.R. Gênero e Saúde. Porto Alegre: Artes Médicas, 1996. p. 7-18.

LOYOLA, M.A. Sexo e sexualidade na antropologia. In.: LOYOLA, M.A. (Org.). Sexualidade nas ciências humanas. Rio de Janeiro: UERJ, 1998. p. 17-47.

MADEIRA, A.M.F.; TSUNCHIRO, A.A. Crescer com o filho: a singularidade do adolescer mãe. In. MERIGHI, M.A.B.; PRAÇA, N.S. Abordagens teórico-metodológicas qualitativas: a vivência da mulher no período reprodutivo. Rio de Janeiro: Guanabara/Koogan, 2003. p.59-80.

MAQUIEIRA D’ANGELO, V. Gênero, diferencia y desigualdad. In.BELTRÁN, E.; MAQUIEIRA D'ANGELO, V.; ÁVAREZ, S.; SÁNCHES, C. Feminismos debates teóricos comtemporáneos. Madri: Alianza edidorial, 2001. p.127-90.

MARCOLINO, C.; GALASTRO, E.P. As visões feminina e masculina acerca da participação de mulheres e homens no planejamento familiar. Rev LatinoamEnfermagem, Ribeirão Preto, v. 9, n. 3, p. 77-82, maio 2001.

MARCON, S.S. Criando os filhos e construindo maneira de cuidar. In: ELSEN, I.; MARCON, S.S.; SANTOS, M.R. O viver em família e sua interface com saúde e a doença. Maringá: Eduem, 2002. p.25-43.

MEDEIROS NETO, X.T., A crueldade do trabalho infantil. Diário de Natal, Natal, 21 out. 2000. Disponível em: <http://www.pgt.mpt.gov.br/publicacoes/trab_inf.html $>$ : Acesso em: 29 dez. 2004.

MEIHY, J.C.S.B. Manual de história oral. São Paulo: Loyola, 1996. 
MEYER, D.E. Do poder ao gênero: uma articulação teórico-analítica. In: LOPES, M.J.; MEYER, D.E.; WALDOW, V.R. Gênero e Saúde. Porto Alegre: Artes Médicas, 1996. p. 41-51.

MINAYO, M.C.de S.O. Ciência, técnica e arte: desafio da pesquisa social. In: MINAYO, M.C.de S.O. (Org.). Pesquisa social: teoria, método e criatividade. Petrópolis: Vozes, 2000. p.9-29.

MINAYO, M.C.de S.O. O desafio do conhecimento: pesquisa qualitativa em saúde. São Paulo-Rio de Janeiro: HUCITEC-ABASCO, 1996.

MONTEIRO, S. Gênero, saúde e proteção entre jovens um perfil tradicional. In. BARBOSA. R.M.; AQUINO, E.M.L.; HEIBORN, M.L.; BERQUÓ, E. Interfases gênero, sexualidade e saúde reprodutiva. Campinas: Unicamp, 2002. p. 23-48.

MOORE, H.L. Antropologia y feminismo. 3. ed. Traducción Jerómima García Bonafé. Madri: Ediciones Cátedra, 1999.

MOTTA, A.B. A categoria geração na pesquisa científica. In: SEMINÁRIO NACIONAL DE PESQUISA EM ENFERMAGEM, 12, 2003 , Porto Seguro, Anais. Porto Seguro: Associação Brasileira de Enfermagem/seção Bahia, 2003. CD-Rom.

MTV Brasil. Pacto MTV: trabalho Infantil. Brasil, 2003. Disponível em: $<$ http://www.mtv.com.br/especiais/pacto/tema02.shtml>. Acesso em: 29 dez. 2004.

NICHOLSON, L. La interpretación Del concepto de gênero. In. TUBERT, S. Del sexo al género: los equivocos de un concepto.Madrid: Ediciones Cátedra, 2003, p. 47-82.

OLIVEIRA, M.W. Gravidez na adolescência: dimensões do problema Cad. CEDES, Campinas, v. 19, n. 45, 1998. Disponível em <http://www.sielosp.org/egi-bin/fbtext?go...>. Acesso em: 28 set. 2002.

ORGANIZAÇÃO DAS NAÇÕES UNIDAS. Atlas do desenvolvimento humano no Brasil. PNDU. Nova York, 2000. Disponível em: <http://www.pndu.org.br/atlas $>$. Acesso em: 10 jun. 2004.

ORGANIZAÇÃO DAS NAÇÕES UNIDAS. Convención sobre la eliminación de todas las formas de discriminación contra la mujer. Nova York, 1979. Disponível em: $<$ http://www.ohchr.org/spanish/law/cedaw.htm>. Acesso em: 28 fev. 2005.

ORGANIZAÇÃO DAS NAÇÕES UNIDAS. Informe sobre a cuarta conferencia mundial sobre la mujer. Nova York, $1995 . \quad$ Disponível em: $<$ http://www.onu.org/documentos/confererencias/1995/beijing/20rt.pdf $>$. Acesso em: 20 jan. 2005.

ORGANIZAÇÃO DAS NAÇÕES UNIDAS. Protocolo facultativo de la convención sobre la eliminación de todas las formas de discriminación contra la mujer. Nova York, 1999. Disponível em: <http://www.ohchr.org/spanish/law/cedaw-one>. Acesso em: 28 fev. 2005. 
ORGANIZAÇÃO INTERNACIONAL DO TRABALHO. Programa Internacional para la erradicación del trabajo infantil. América Latina/Caribe: IPEC. Disponível em: $<$ http://www.oit.org.pe/spanish/260ameri/oitreg/activid/proyectos/ipec/index.php $>$. Acesso em: 27 dez. 2004.

ORGANIZAÇÃO MUNDIAL DE SÁUDE. La salud de los jovenes um desafio para la sociedad; informe de grupo de estúdios de la OMS acerca de los jovenes y la "Salud para Todos en el año 2000”. Genebra: 1986 (Série Informes Técnicos: 731).

ORGANIZAÇÃO MUNDIAL DE SÁUDE. Saúde reprodutiva de adolescentes: uma estratégia para ação. Genebra: OMS/FNUAP/ UNICEF, 1989.

ORTNER, S.B. Está a mulher para o homem assim como a natureza para a cultura. In: ROSALDO, M.Z.; LAMPHERE, L. A mulher a cultura a sociedade. Rio de Janeiro: Paz e Terra, 1979, p. 95-118.

OUTEIRAL, J.O. Adolescer: estudos sobre adolescência. Porto Alegre: Artes Médicas, 1994.

PANTOJA, A. L. N. Análise sócio-antropológica da gravidez/maternidade na adolescência. Cad. Saúde Pública, Rio de Janeiro, v. 19, n. 2, p. S335-S343, 2003.

PITANGY, J. (Org.) A questão de gênero no Brasil. Brasília/Rio de Janeiro: Banco Mundial/CEPIA, 2003.

PITANGY, J. O movimento nacional e internacional de saúde. In: GIFFIN, K.; COSTA, S.H. (Org.). Questões da saúde reprodutiva. Rio de Janeiro: Fiocruz, 1999. p.19-38.

PITANGY, J. Saúde, mulher e sociedade: uma introdução para o debate. In: PITANGY, J.; MESQUITA, R. Gênero, Corpo e Enfermagem. Rio de Janeiro: CEPIA, 2002. p. 11-21.

QUEIROZ, M.I.P. Relatos orais: do "indivizível" ao "dizível”. In: SIMSON, O.M.V. Experimentos com histórias de vida. São Paulo: Vértice, 1988, p.14-43.

RAGO, M. Feminizar é preciso: por uma cultura filógina. Perspec., São Paulo. v. 15, n. 3, p.53-66, jul./set 2001. Disponível em: $<$ http://www.scielo.br/scielo.php?script=sci_arttext\&pid=S0102$88392001000300009 \& \operatorname{lng}=$ pt\&nrm=isso $>$. Acesso em: 24 ago. 2002.

RIOS, L.F.; PIMENTA, C.; BRITO, I.; TERT JR.;V.; PARKER, R. Rumo à adultez: oportunidades e barreiras para a saúde sexual dos jovens brasileiros. Cad. CEDES. Campinas, v. 22, n. 57, p.45-61, ago. 2002. Disponível em: $<$ http://www.scielo.br/scielo.php?script=sci_arttext\&pid=S0101$32622002000200004 \& \operatorname{lng}=$ pt\&nrm=iso $>$. Acesso em: 20 out. 2003

ROSALVO, M.Z. A mulher, a cultura e a sociedade: uma revisão teórica. In: ROSALVO, M.Z.; LAMPHERE, L. A mulher a cultura a sociedade. Rio de Janeiro:Paz e terra, 1979. p. 33-64. 
SAITO, M.I. Adolescência, sexualidade e educação sexual. Pediatria Moderna, São Paulo. v. 37, p. 3-6, maio 2001.

SALEM, T. "Homem já viu, né?": representações sobre sexualidade e gênero entre homens da classe popular. In: HEILBORN, M.L. Família e sexualidade. Rio de Janeiro: FGV, 2004. p. 15-61.

SANTOS, R.L.A. Jovens mães e processos de construção de suas "identidades". 2001. 185p. Dissertação (Mestrado) - Faculdade de Saúde Pública, Universidade de São Paulo, São Paulo, 2001.

SCOTT, J. Gênero: uma categoria útil para análise histórica. Tradução Guacira Lopes Louro. Porto Alegre: Rev. Educação e realidade, Porto Alegre. v. 20, p.71-99, 1995.

SWAIN, T.N.. Feminismo e recortes do tempo presente: mulheres em revistas "femininas". São Paulo em Perspec, São Paulo. v.15, n.3, p.67-81. jul./set 2001. Disponível em: $<$ http://www.scielo.br/scielo.php?script $=$ sci_arttext\&pid=S0102-

$88392001000300010 \& \operatorname{lng}=$ pt\&nrm=iso $>$. Acesso em: 25 ago. 2003.

TAQUETE, S.R. Sexo e gravidez na adolescência. Jornal de Pediatria, Rio de Janeiro, p. 125-39, mar.-abr. 1992.

THOMPSON, P. A voz do passado: história oral. 2. ed. Tradução Lólio Lourenço de Oliveira. Rio de Janeiro: Paz e Terra, 1998.

TORRES, M.R. Sexo, prazer e dor. Vivências sexuais na fala de adolescentes pobres de Salvador. In. BARBOSA. R.M.; AQUINO, E.M.L.; HEIBORN, M.L.; BERQUÓ, E. Interfases - gênero, sexualidade e saúde reprodutiva. Campinas: Unicamp, 2002. p. 4983.

TRAVERSO-YÉPEZ, M.A.; PINHEIRO, V.S. Adolescência, saúde e contexto social: esclarecendo práticas. Psicologia e Sociedade, Porto Alegre, v. 14, n. 2, p.133-47, jul./dez. 2002.

TRINDADE, R.F.C. Gravidez na adolescência: análise do padrão reprodutivo. 2001, 122p. Dissertação (Mestrado) - Escola de Enfermagem de Ribeirão Preto, Universidade de São Paulo, Ribeirão Preto, 2001.

TRINDADE, R.F.C.; ALMEIDA, A.M. Gravidez na adolescência: alguns indicadores obstétricos na periferia de Maceió/Al. In: SEMINÁRIO-APEC, 9. 2004, Barcelona. Actas Pluriculturalismo y globalización: producción del conocimiento para la construcción de la ciudadanía en Latinoamérica. Barcelona: Asociación de Investigadores y Estudiantes Brasileños en Cataluña/Instituto Catalá de Coperació Iberoamericana. 2004. p.271-80.

TUBERT, S. Del sexo al género: los equivocos de un concepto. Madrid: Ediciones Cátedra, 2003. 
VALÉRY, F.D. À la crisée des chemins: mulher e cidadania na nova ordem social. In: FONSECA, R.M.G.S. Mulher e cidadania na nova ordem social. São Paulo: Núcleo de Estudos da Mulher e Relações Sociais de Gênero, 1996, p.26-42.

VALLES, M.S. Técnicas cualitativas de investigación social: reflexión metodológica y práctica profesional. Madrid: Síntesis, 1999.

VITIELO, N. Sexo na adolescência uma introdução ao tema. In. CAVALCANTI, R.C.; VITIELO, N. Sexologia - I. Comissão Nacional de Sexologia da Febrasgo. São Paulo: Roca, 1986.

WAGNER, A. FALKER, D. SILVEIRA, L.M.B.O, MOSMANN, C.P. A comunicação em famílias com filhos adolescentes. Psicol. estud., Maringá, v. 7, n. 1, jan./jun. 2002. Disponível em: < http://www.scielo.br/pdf/pe/v7n1/v7n1a08.pdf >. Acesso em: $27 \mathrm{dez}$. 2004

WAGNER, A.; FALCKE, D.; MEZA, E. B. D. Crenças e valores dos adolescentes acerca de família, casamento, separação e projetos de vida. Psicol. Reflex. Crit., Porto Alegre, v.10 n.1, 1997. Disponível em: < http://sielo.br>. Acesso em: 27 dez. 2004

WITT, R.R. Gênero e diabetes: implicações para o auto-cuidado. In: LOPES, M.J.; MEYER, D.E.; WALDOW, V.R. (Org.). Gênero e Saúde. Porto Alegre: Artes Médicas, 1996, p. 19-27. 


\section{APÊNDICE A -}

\section{ETIQUETA DAS FITAS}

PESQUISA: Entre o sonho e a realidade: a maternidade na adolescência sob a ótica de um grupo de mulheres da periferia da cidade de Maceió - Alagoas

PESQUISADORA: Ruth França Cizino da Trindade

ENTREVISTA - número - Nome:

Endereço:

Local da entrevista:

Datas das entrevistas: $1^{\mathrm{a}}$ Fita no. $; 2^{\mathrm{a}}$

TRANSCRIÇÃO:

Fita no. $\quad \underline{\text { Lado }}$ Pág. da transcrição

OBSERVAÇÕES: 


\section{APÊNDICE B -}

\section{TERMO DE CONSENTIMENTO LIVRE E ESCLARECIDO}

Estou realizando uma pesquisa com o nome de: Entre o sonho e a realidade: a maternidade na adolescência sob a ótica de um grupo de mulheres da periferia da cidade de Maceió - Alagoas, ou seja, como a mulher que engravidara com menos de 20 anos de idade avalia ter sido mãe na adolescência e com isso espero poder conhecer o sentido da maternidade entre vocês e identificar como se formou a sua idéia de ser mãe. A sua experiência vai poder ajudar a compreender melhor o que acontece com as mulheres quando elas engravidam antes dos 20 anos.

Como é um trabalho de história, preciso conversar com você ou seja entrevistá-la, e pode ser que precise que isso aconteça mais de uma vez. Em nenhum momento você será exposta a algum perigo, contratempo ou inconveniente devido a sua participação nesta pesquisa e poderá a qualquer momento recusar-se a continuar, sem nenhum prejuízo para sua pessoa. Se aceitar, a nossa conversa será gravada, e seu conteúdo será escrito e usado somente para fins deste estudo, com garantia de que não será identificada em nenhum momento, seja durante no fim ou quando a pesquisa for divulgada. Como é um estudo sobre sua história, gostaria que você escolhesse um nome para que seja colocada nela. Você, também não terá nenhuma despesa nem receberá pagamento ou gratificação pela sua participação nessa pesquisa.

Assim sendo peço a você que me autorize a:

( ) gravar a entrevista em fita cassete, caso não se sinta constrangida;

( ) utilizar das informações da(s) entrevista(s) por você dada;

( ) usar o nome que você escolheu para identificar a sua história.

Nome:

Diante do exposto, Eu, anos, portadora do documento _ $\mathrm{n}^{\circ}$, declaro

estar ciente das informações recebidas e concordo, voluntariamente, em participar do referido estudo.

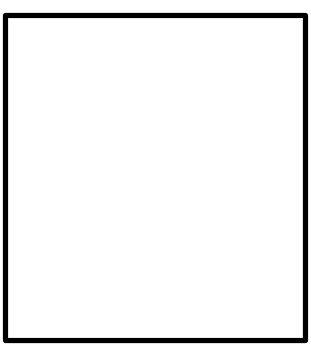

Local: Maceió Data:

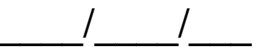

Ass.:

Entrevistada

Polegar direito 